University of Louisville

ThinkIR: The University of Louisville's Institutional Repository

Electronic Theses and Dissertations

8-2014

\title{
Analysis of social costs of gentrification in Over-the-Rhine : a qualitative approach.
}

Shireen Deobhakta

University of Louisville

Follow this and additional works at: https://ir.library.louisville.edu/etd

Part of the Urban Studies and Planning Commons

\section{Recommended Citation}

Deobhakta, Shireen, "Analysis of social costs of gentrification in Over-the-Rhine : a qualitative approach." (2014). Electronic Theses and Dissertations. Paper 336.

https://doi.org/10.18297/etd/336

This Doctoral Dissertation is brought to you for free and open access by ThinkIR: The University of Louisville's Institutional Repository. It has been accepted for inclusion in Electronic Theses and Dissertations by an authorized administrator of ThinkIR: The University of Louisville's Institutional Repository. This title appears here courtesy of the author, who has retained all other copyrights. For more information, please contact thinkir@louisville.edu. 


\title{
ANALYSIS OF SOCIAL COSTS OF GENTRIFICATION IN OVER-THE-RHINE: A QUALITATIVE APPROACH
}

\author{
By \\ Shireen Deobhakta \\ B.A., Ohio Wesleyan University, 2000 \\ MBA, The Ohio State University, 2004 \\ A Dissertation \\ Submitted to the Faculty of the \\ College of Arts and Sciences of the University of Louisville \\ in Partial Fulfillment of the Requirements \\ for the Degree of \\ Doctor of Philosophy \\ Department of Urban and Public Affairs \\ University of Louisville \\ Louisville, Kentucky
}

August, 2014 
Copyright 2014 by Shireen Deobhakta

All rights reserved 



\title{
ANALYSIS OF SOCIAL COSTS OF GENTRIFICATION IN OVER-THE-RHINE: A QUALITATIVE APPROACH
}

\author{
By \\ Shireen Deobhakta \\ B.A., Ohio Wesleyan University, 2000 \\ MBA, The Ohio State University, 2004
}

A Dissertation Approved on

May 16, 2014

By the following Dissertation Committee:

Dissertation Director

Dr. Cynthia Negrey

Dr. Mark Austin

Dr. Janet Kelly

Dr. Patricia Gagne’ 


\section{DEDICATION}

This dissertation is dedicated to my Ma, Sunita Deobhakta, and to my sister, Priyanka Deobhakta. They have always been my anchors in life and I feel grateful to them for always being there for me. 


\section{ACKNOWLEDGEMENTS}

I would like to thank Dr. Cynthia Negrey for her guidance, mentorship, direction, and assistance throughout the course of my tenure at the University of Louisville. Over the years, she has helped me become a better scholar, and I will always be indebted to her. I also appreciate the guidance and contribution of my other committee members, Dr. Mark Austin, Dr. Patricia Gagne', and Dr. Janet Kelly. In addition, I would like to thank the professors and staff of the School of Urban and Public Affairs and the Department of Sociology, with special appreciation for the constant encouragement and support of Juli Wagner, Yani Vozos, and Patricia Sarley. I would also like to express my appreciation for my family and friends, in particular, my grandmother, Shashikala Kulkarni, Dr. Carey Addision, Isabella Christenson, Andrea Pompei Lacy, and Brandi Scott. I would like to extend a special thank you to my partner, Donald Dean, for his unwavering support and patience through this process.

And, finally, I must thank my dogs, Breeze and Rousseau, for going through this rollercoaster ride with me. 


\title{
ABSTRACT \\ ANALYSIS OF SOCIAL COSTS OF GENTRIFICATION IN OVER-THE-RHINE: A QUALITATIVE APPROACH
}

\author{
Shireen Deobhakta
}

May 16, 2014

This study examines the social costs and benefits of the gentrification process using qualitative methods. The neighborhood of Over-the-Rhine (OTR) in Cincinnati, Ohio, represents certain universalities of gentrification in an older city, and was thus chosen as the site for a case study. OTR's prime location between the Central Business District and uptown medical and university community has spurred rapid gentrification, particularly since the early 2000s. Using in-depth interviews, participant observation, a focus group, and print media, this dissertation sought to understand the social costs and benefits of gentrification in OTR.

Adopting the language of "revitalization" and "renaissance," the city of Cincinnati formed the Cincinnati Center City Community Development Corporation (3CDC) as its economic development arm. Unlike traditional CDCs which act as liaisons between the community and the city, 3CDC plays the role of the main developer. $3 \mathrm{CDC}$ has the full political and financial backing of the city and the corporate community, enabling it to take redevelopment in OTR from pocket-sized development to one largescale development effort. This devolution and privatization of power is a testament to Cincinnati adopting a neoliberal imperative. 
Today, the city is no longer the regulator of development, but instead, its progenitor. Acting in tandem with $3 \mathrm{CDC}$, the developers, and the corporate interests, the city has adopted policies geared toward attracting the middle- to upper-middle income class back to its urban core. Conspicuously missing from the decision-making table are OTR's longtime residents, social service organizations, advocacy groups, and the displaced and homeless.

This study examines the social costs and benefits of gentrification, going beyond a profitability analysis and incorporating the voices of all the actors involved in the process of gentrification, using qualitative analysis. By taking into account all perspectives, this study permits a holistic understanding of the social costs and benefits associated with gentrification.

As expected, the greatest social cost of gentrification is displacement and the erosion of social capital. In OTR, gentrification also caused a palpable rift between its proponents (city, 3CDC, developers, corporate interests, and newcomers) and its opponents (longtime residents, social service organizations, advocacy groups, and the displaced and homeless). The greatest social benefits include increased tax receipts, social mixing via de-concentration of poverty, and an upgrading of the disinvested neighborhood.

Some unexpected findings included the fact that in addition to the welldocumented positive "trickle-down" effects of gentrification via social mixing, there are also positive "trickle-up" effects. Another unexpected finding was that although the displaced are typically portrayed as being voiceless and disenfranchised, the in-depth interviews revealed that displacees were actually empowered by their experiences, 
finding greater resiliency and spirituality. Two of the six displacees interviewed also said they chose to remain homeless because it brought them greater happiness.

As gentrification becomes more pervasive in cities across America, a holistic tally of the social costs and benefits of revitalization projects becomes imperative. When social and monetary costs are tallied against social and monetary benefits, the true costs may in fact be greater than the true benefits. The study concludes with policy recommendations for Cincinnati and other cities that are considering revitalizing their urban cores. 


\section{TABLE OF CONTENTS}

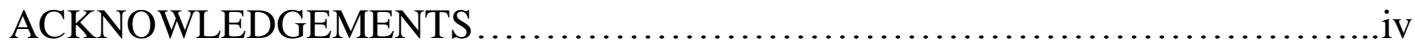

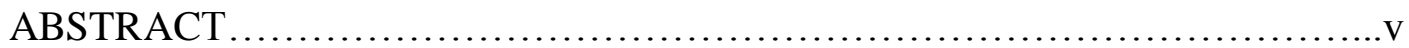

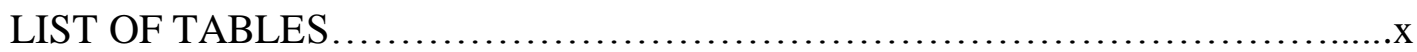

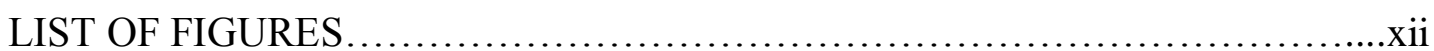

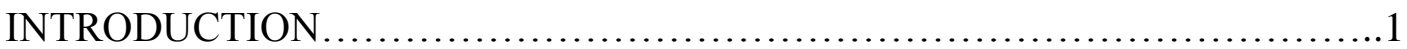

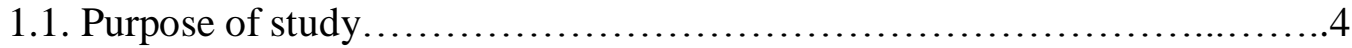

1.2. Organization of study..........................................

LITERATURE REVIEW.............................................6

2.1. Social production of space......................................6

2.1.1. Uneven development of space................................ 9

2.1.2. Space as a commodity...................................... 11

2.2. Gentrification................................................... 13

2.2.1. Definition.................................................. 13

2.2.2. Explanations for gentrification............................... 14

2.2.3. Historical context............................................ 19

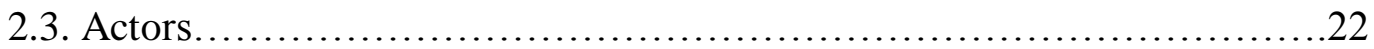

2.3.1. Political dimension - changing role of the state..................23

2.3.2. Economic dimension - the incursion of global capital...............32

2.3.3. Social dimension - resistance movements........................34

2.4. Costs and benefits of gentrification................................... 36

2.4.1. Costs of gentrification..................................... 37

2.4.2. Benefits of gentrification.......................................

METHODS ............................................................ 42

3.1. Over-the-Rhine...................................................... 42

3.1.1. Over-the-Rhine history and demographic characteristics.............43

3.2. Research questions................................................. 56

3.2.1. Umbrella questions.......................................56

3.2.2. Specific questions.............................................56

3.3. Methodology ...................................................... 58

3.3.1. Direct contact............................................63

3.3.2. Snowball sampling........................................64

3.3.3. Systematic random sampling...............................64 
3.4. Demographic details of interviewees..................................66

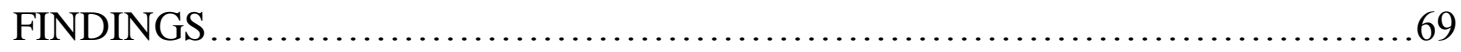

4.1. Revitalization and redevelopment in Over-the-Rhine.........................69

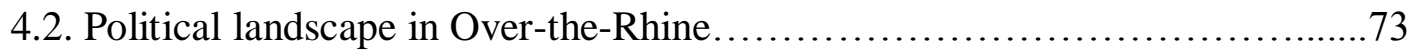

4.2.1. Corporate landscape in Over-the-Rhine................................74

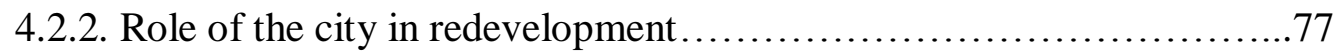

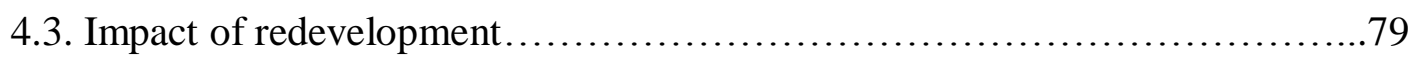

4.3.1. Longtime residents and redevelopment.............................79

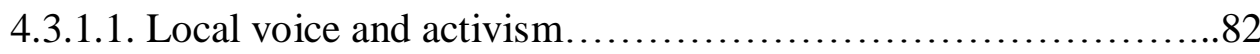

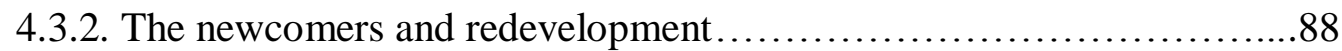

4.3.3. Interaction between longtime residents and newcomers...............992

4.3.4. Social service organizations and redevelopment.....................96

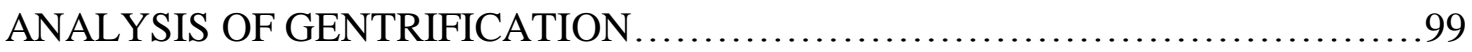

5.1. Social benefits...................................................99

5.1.1. Creating a culture of aspiration.................................99

5.1.2. Washington Park............................................ 102

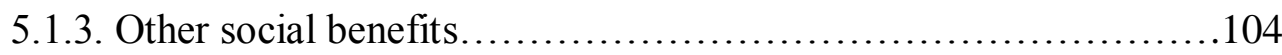

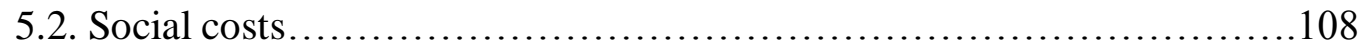

5.3. Displacement and retention...................................... 112

5.3.1. The displaced and the homeless.................................. 115

5.3.2. "People in the margins"........................................114

5.4. Revitalization versus gentrification................................ 117

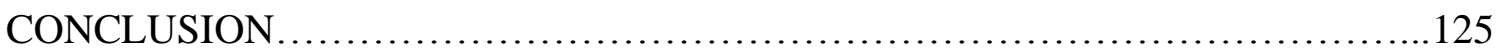

6.1. Summary of findings............................................... 129

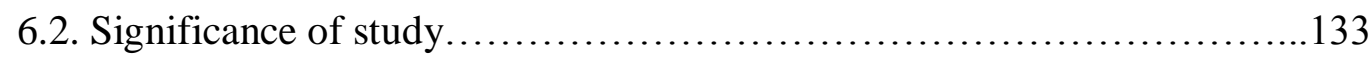

6.2.1. Policy recommendations.......................................134

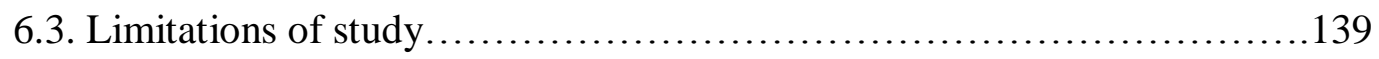

6.4. Areas for further research........................................ 140

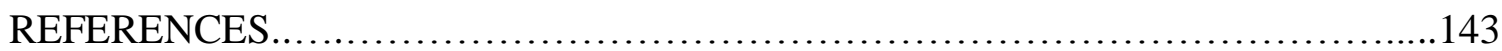

APPENDIX: INTERVIEW QUESTIONS ...................................... 155

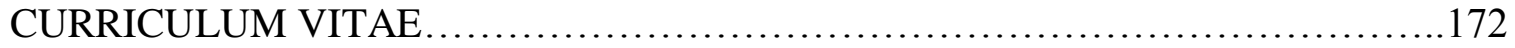




\section{LIST OF TABLES}

TABLE 1: Cost and Benefits of Gentrification.................................... 37

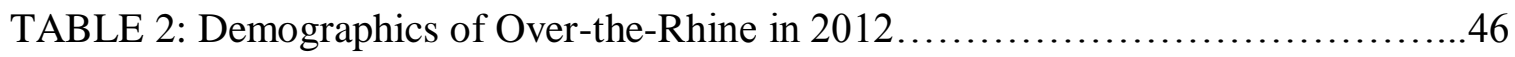

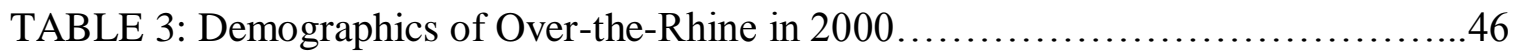

TABLE 4: Housing Indicators in Over-the-Rhine..............................47

TABLE 5a.1. Household Statistics in Over-the-Rhine...........................49

TABLE 5a.2. Household Statistics in Over-the-Rhine.............................49

TABLE 5b: Household Statistics in Over-the-Rhine...............................50

TABLE 5c: Household Statistics in Over-the-Rhine..............................50

TABLE 6: Educational Enrollment and Attainment in Over-the-Rhine..................52

TABLE 7. Median Earnings by Educational Attainment............................54

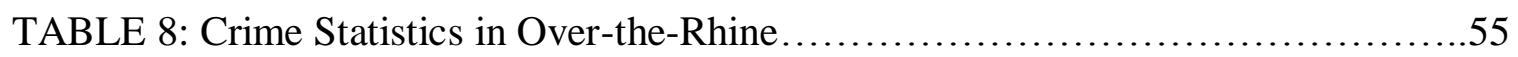

TABLE 9: Breakdown of Interviewees....................................60

TABLE 10: Demographics of Interviewees..................................67

TABLE 11: Overall Demographics of New Home Buyers $(2008$ - 2012)..............90

TABLE 12: Over-the-Rhine Living Sales and Marketing ReCap (2007 - 2012)........91 
TABLE 13: Residency Status 1 Year Ago. .95 


\section{LIST OF FIGURES}

FIGURE 1: Rent Gap.................................................... 16

FIGURE 2a: Location of Over-the-Rhine in Cincinnati, Ohio......................44

FIGURE 2b: The Over-the-Rhine Neighborhood of Cincinnati, Ohio................45

FIGURE 3: Crime Statistics Comparing OTR to Neighborhood Average...............55

FIGURE 4: Over-the-Rhine Interviewees...................................61

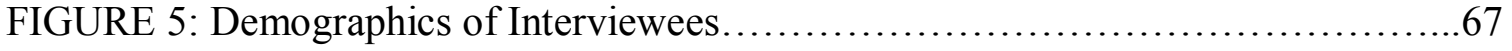

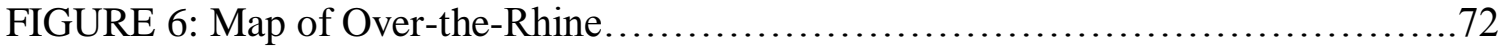

FIGURE 7: Demographics of Home Buyers...................................89 


\section{CHAPTER 1}

\section{INTRODUCTION}

Gentrification is a form of socio-spatial urban development wherein working class or lower-income residential neighborhoods are transformed into middle-class residential or commercial neighborhoods, resulting in the displacement and geographical reshuffling of existing residents. The past two decades have witnessed a third-wave gentrification and arguably a fourth-wave gentrification wherein the recession of the early 1990s was followed by a more state-led form of gentrification - this dissertation uses the terms 'state-led, 'government-led,' and 'municipal-led,' interchangeably (Hackworth and Smith, 2001; Lees et al, 2008). Side-stepping the negative connotations associated with the term 'gentrification', city officials have adopted and embraced the language of "urban renaissance” and "community regeneration" (Lees, 2003a; 2008; Lees and Ley, 2008). Urban renewal efforts are often portrayed as beneficial to the city, leading to less segregated and more sustainable communities ('the emancipatory city thesis'). The purpose of this dissertation is to analyze the social costs and benefits of gentrification using qualitative methods.

A shift from a Keynesian form of social governance to neoliberal models of urban governance via economic development initiatives has led to the state becoming a more 
aggressive actor in shaping the socioeconomic environment of cities (Addie, 2008;

Hackworth, 2002b). As cities employ boosterist strategies focused on attracting footloose capital in the form of corporate interests, creating "a sustainable city" has become an ordinary slogan for political campaigns. Cities are at the mercy of constant competition to increase their tax base; as a result more recently, state intervention and government programs have begun to mold inner-city redevelopment. Social mixing initiatives that deconcentrate the poor and attract the middle class back to the city have become a means of escape from the "blight" that plagues inner cities. Increased state support manifests itself in the form of "urban renewal" or "revitalization" efforts with greater developer involvement in the early stages of gentrification.

The decision to revitalize disinvested neighborhoods rests in the hands of elite interests - city officials, real estate developers, and investors. Conspicuously missing from the table are the existing residents of these neighborhoods. The elites are unified via a "growth consensus" that works to "eliminate any alternative vision of the purpose of local government or the meaning of community" (Logan and Molotch, 1987 p. 51).

Policy-makers view gentrification as a means to improve the quality of deteriorated neighborhoods and mix residents from different socioeconomic backgrounds, bringing vibrancy to a previously decrepit neighborhood (Freeman, 2006). Another celebrated aspect of gentrification is an increase in property tax revenues as more affluent newcomers replace lower-income residents.

There has been substantial debate on state-led gentrification as a 'positive public policy tool' (Cameron, 2003; Lees et al., 2008; Davidson, 2008; Slater, 2004). Many 
scholars contend that it leads to further socio-spatial polarization, exacerbating the very problems it hopes to ease (Hamnett, 2003; Lees and Ley, 2008). Atkinson (2002) identifies nine interrelated impacts associated with the gentrification process: displacement; harassment and eviction; community conflict; loss of affordable housing; homelessness; change to local service provision; social displacement; crime; and population loss. Some argue that recent waves of gentrification are nothing more than a strategy to actively secure greater tax revenues under the auspices of curing inner-city ills (Slater, 2004).

There has been extensive scholarly debate on the costs and benefits of gentrification. Much of this debate has revolved around studying the quantifiable costs and benefits of gentrification, for example, comparing initial outlays to subsequent tax receipts (Lang, 1986). There has been little attention devoted to analyzing the social costs and benefits of such a form of gentrification by design, one that is inclusive of "externalities" such as the loss of social capital and community networks or the increase in safety. The paucity of information on a comprehensive accounting of the costs and benefits of gentrification is regrettable because it presents policy makers with a very myopic lens when considering urban renewal projects. By only analyzing quantifiable costs and benefits of urban renewal projects, policy makers do not incorporate the voices of the participants of the gentrification process. One issue that arises, then, is that quantitative analyses are inadequate to describe and explain the costs and benefits of gentrification. 


\subsection{Purpose of Study}

This qualitative study adds to the research literature by analyzing the social costs and benefits of the gentrification process. This dissertation uses a case study format, focusing on the Over-the-Rhine (OTR) neighborhood in Cincinnati, Ohio. The qualitative data, gathered via in-depth interviews, a focus group, participant observation, and print media probes and explores the "intangible" costs and benefits associated with gentrification in order to gain a more holistic picture of the gentrification process.

\subsection{Organization of Study}

Chapter 2 presents a review of scholarly literature on the production of space and in particular, gentrification. It first describes the social production of space and uneven development, situating it within a broader context of economic and political forces that shape the restructuring process. It then describes the process of gentrification as is prevalent today and reviews explanations for gentrification, situating the process within a historical context. Next, it focuses on the growth consensus and the main actors that shape the process of gentrification. Fourth, it enumerates the costs and benefits of gentrification.

Chapter 3 presents a methodological framework for the study. It first presents details on the site chosen for the case study, Over-the-Rhine. Next, it discusses the history and demographic characteristics of the neighborhood, with special emphasis on the redevelopment that is currently taking place within OTR. It presents the overarching research questions used to guide the study as follows: 
1. What is the rationale for redeveloping Over-the-Rhine?

2. What are the relationship dynamics amongst various actors in the redevelopment efforts?

3. Who has decision making power?

4. What are the perceived social costs and benefits of gentrification?

The chapter further discusses the methodology used, in the form of in-depth interviews, a focus group, participant observation, and print media. The chapter ends with a description of the demographic characteristics of the interviewees.

Chapter 4 presents the qualitative findings from the study. It discusses the revitalization and redevelopment that is occurring in OTR, followed by a description of the political landscape. It then discusses the impact of redevelopment on longtime residents, newcomers, and social service organizations. Chapter 5 presents an analysis of gentrification in OTR, focusing on the social costs and benefits of the process. It also discusses displacement in greater detail, and the distinction between the often interchangeable terms 'revitalization' and 'gentrification.'

Chapter 6 summarizes key findings, and discusses the significance of the study, with special emphasis on policy recommendations, limitations of the study, and areas for future research. 


\section{CHAPTER 2}

\section{LITERATURE REVIEW}

\subsection{Social production of space}

Space is an inter-dimentional, multi-faceted concept. It is at once a simple and complex idea with multiple and sometimes contradictory meanings. Space cannot be reduced to simply the built environment or location or social relations of property ownership. Space is a physical location, a piece of real estate, a site for buildings and infrastructure. It is also a container of human activity; it is a place to live and work- a site for action or the possibility for action (Gottdeiner, 1994; Lefebvre, 1974; Castells, 1977).

Space holds a central place in both the individual and collective psyches. An individual's relation to that space creates memories, associations, a sense of belonging, community, and ultimately the formation of an identity. As such, space becomes a place. Each of us has places that are meaningful to us but "places also have collective meanings and memories - the local swimming pool saved from demolition by community fundraising... a roadside memorial to a local character. In these terms, place also has spirit, memory and desire” (Porter and Barber, 2006, p. 227-228). As Blomley (2004) states "while property can, indeed, be individualistic and reified, it also contains more collective and fluid meaning" (p. 91). 
Communities are place based; however, there exists "some form of communal connection among individuals - whether or not such connection is locality based - that provides for the possibility of group identity and collective action" (Chaskin, 1997, p. 522). Neighborhoods, on the other hand, are a spatial construction of a geographic unit based on shared proximity (Ibid.).

Places are not created equally. The urban built environment is characterized by uneven geographic and economic development. This includes stratification according to class or income and race, expressed as disparate land-use patterns ranging from suburban enclaves to high rises to ghettos.

Unequal development and the resulting socioeconomic polarization lead to pathologies such as concentrated poverty and blight that are then described as spatial problems. The urban poor, while geographically central, have become culturally, socially, and economically marginal (Wilson, 1989). The resulting "concentration effects" lead to outcomes such as crime, joblessness, and pathological delinquency.

Government-sponsored interventions to mitigate urban social problems have included initiatives that directly and indirectly promote gentrification. Cities, in an effort to revitalize disinvested neighborhoods, have embraced greater private developer involvement in the early stages of the restructuring process. As cities become more entrepreneurial, competing for investors, residents, businesses and tourists, public-private partnerships have become a welcome salvation (Hackworth and Smith, 2001). Private developer involvement includes transforming swathes of devalued property into chic residential condominiums and modish art galleries, thus spurring gentrification and 
displacement of the original residents. Public-private partnership manifests itself in the form of developer subsidies such as "progressive" housing policies, Enterprise Zones and tax subsidies (Hackworth, 2002).

Davidson and Lees (2005) argue that "a 'gentrification blueprint' is being massproduced, mass-marketed, and mass-consumed around the world" (p. 1167). As gentrification becomes more developer-driven, it simultaneously becomes more pervasive. Gentrification no longer happens "naturally" with one or two "urban pioneers" moving into the disinvested neighborhood. It takes place in bulk, with massreconstruction, changing the very landscape and constitution of the neighborhood. An inescapable aspect of such gentrification is the displacement of the original residents either forcibly through evictions or indirectly through rent increases or spiraling property values.

Gentrification is a spatial representation of social inequality in the form of uneven development. Revitalization efforts portray it as a positive sign of a healthy real estate market (see Lees et al., 2008, p. 165). If we are concerned about injustice, the measurement of inequities cannot be reduced or limited to the geography of resource allocation (Porter and Barber, 2006, p. 228). It must also include dimensions of culture, place, and belonging. The displacement of existing residents is a flip side of the coin of gentrification. Any analysis weighing the net benefits of gentrification should account for the unavoidable social costs of displacement. This dissertation attempts to do so using qualitative analysis. 
Given the various economic and political forces involved in the restructuring of urban space, it becomes important to first understand the concept of the Urban and the economic, political, and social forces that shape the uneven development of space.

\subsubsection{Uneven development of space}

The relationship between social processes and urban form has been the subject of numerous studies. The paradigm of Urban Ecology accepts city form as a result of free market forces. Using a complex analogy of organicism (Comte, 1875), Darwinism (Spencer, 1909), and a laissez-faire economic framework, ecologists explain the urban form as a result of the division of labor (Turner, 1978). Comte (1875) views cities as "real organs" of social organism in a complex biological analogy while Spencer (1909) stresses the division of labor according to the biological analogy of size leading to functional differentiation (Gottdeiner, 1994).

According to the early Chicago School (Park, 1925; McKenzie, 1924), uneven development was initially characterized as a result of economic and cultural dimensions and a "natural" filtering of populations. Following the work of Von Thunen (1866) and Weber (1899), Burgess (1925) describes how a city goes through a pattern of centralization and decentralization, a functional version of the invasion-succession cycle (McKenzie, 1925) wherein different ethnic groups and economic functions locate themselves spatially. His model describes a "zone of transition" (which Harvey (1976) refers to as the devaluation of the built environment (Gottdeiner, 1994, 31)) which contains neglected slum development next to the central business district (CBD). 
Acknowledging the role of real estate speculators, Burgess describes how the zone in transition waits for redevelopment as the CBD decentralizes and recentralizes. For Burgess, this uneven development is the "direct product of land speculation and economic competition” (Gottdeiner, 1994, 32).

The theory of uneven development received renewed interest after World War II, when ecologists developed a more abstract formulation of urban social form. The contribution of Hawley (1950) is most noteworthy in explaining uneven development. Instead of Darwin's notion of competitive survival, Hawley, like Park before him, stresses Darwin's symbiotic concept of the "web of life." According to Hawley, symbiosis is distributed unevenly and "since functional differentiation is a fundamental characteristic of the community, commensalism tends to occur disjunctively in each functional category" (1950, p. 209; quoted in Gottdeiner, 1994, p. 38). Shifting away from the concept of competition and stressing the concept of cooperation, Hawley explains uneven settlement (and resulting inequities) as a matter of adaptation and functional integration. Weber and Marx, on the other hand, recognize the powerful forces of unequal distribution of resources in shaping urban space.

According to Marx (1858), the urban form is tied to the mode of production. The Marxian model emphasizes the process of capitalist accumulation, production, and reproduction facilitating a decision-making process which structures the urban form. From a Marxian perspective, the capitalist urban growth process internalizes the production of uneven development and is an inherent part of the process. Uneven development is a result of internal contradiction within the capitalist system - a manifestation of the inherent contradiction between use-value and exchange-value. 
In classical political economy, use-value is the utility derived from consuming a good or service. Marx argues that if the good or service can be traded as a commodity, it additionally has an exchange-value. According to Marx, the inherent contradiction between use-value and exchange-value lies in the fact that use-value is based on the inputs of production while exchange-value is based on market fluctuations, thus suspending "value" between the past and the future.

\subsubsection{Space as a commodity}

David Harvey uses Marxist theory to develop a theoretical framework connecting urban restructuring to the processes of capital accumulation and class struggle. In a series of publications in the 1970s and 1980s, Harvey created a framework for analyzing capitalist investment and profit making within the context of how the built environment is formed. Harvey showed how overaccumulation in the 'primary circuit of capital' (the means of production and the means of consumption) leads to a flow of capital into the 'secondary circuit' in the form of investment in durables and physical infrastructure (the built environment). While this assists capital accumulation, such investment in the built environment may become an obstacle to capital accumulation in the future, thus creating the possibility of a crisis.

According to Harvey, crisis formation can occur at different points in the circuit of capital flows. This is primarily due to the exhaustion of the potentiality for productive investment within that sphere (for example, social expenditures or consumption fund 
formation). Thus, further flows of capital no longer expand the basis for the production of surplus value, setting the stage for a crisis (Harvey 1982, 324-33).

Pressures within the circulation of capital lead to a systematic "annihilation of space by time." Natural landscapes are replaced by built landscapes in a fragmented yet homogenized form, leading to uneven development of space. Harvey observes, "Under capitalism there is...a perpetual struggle in which capital builds a physical landscape appropriate to its own condition at a particular moment in time, only to have to destroy it... at a subsequent point in time" (Harvey, 1989). He describes a process of "creative destruction" (Schumpeter, 1942) whereby the created spaces of capitalism have to be annihilated to make new space, begging the question 'how much more time in this space?' (Ibid.).

In the 1970s and 1980s, gentrification, an articulation of uneven development, began to be seen as an inherent form of social and geographic restructuring rather than a temporal anomaly. Some scholars argued that it was a "back to the city" movement (Laska and Spain, 1980) while others (Lipton, 1977; Smith, 1979) saw it as a more enduring form of urban restructuring. The next section looks at the process of gentrification in greater detail, focusing on its definition and prominent explanations, then situating the process within a historical context. 


\subsection{Gentrification}

\subsubsection{Definition}

The word 'gentrification' evokes images of market-rate condominiums next to boarded-up vacant properties; posters advertising new-build luxury apartments against a backdrop of graffiti-art. Once labeled "a dirty word” (Real Estate Board of New York, 1985), the term has evolved to describe an inherently geographic process that is rooted in class relations.

The notion of class structure and conflict is implicit in the word itself. British sociologist Ruth Glass (1964) coined the term gentrification to describe a marked urban process in which upper-middle class gentry began to "invade" working class neighborhoods in London, displacing the original residents. First used to describe a quaint, localized process, the term soon became institutionalized.

In an effort to better understand the concept, the term and its meaning have become the topic of much scholarly debate. As some scholars have sought to contain the concept within neatly defined stages, others have underscored its complexity and have attempted to provide a more nuanced definition of the process. Early stage models (Clay, 1979; Gale, 1979) succeeded in explaining gentrification as a clean, linear concept. While robust, the models fall short of providing a methodology to explain later processes of gentrification in the 1980s, 1990s, and 2000s (Ibid., 33).

Rose (1984, p. 62) and Beauregard (1986), among others, have argued that gentrification is a 'chaotic concept' with different actors, housing tenures, motives, allegiances. Therefore, they argued, stage models that "lumped together different 
processes and effects" needed to be "disaggregated." As Beauregard has reasoned, "the diversity of gentrification must be recognized, rather than conflating diverse aspects into a single phenomenon" (p. 40).

More recently, Clark (2005) refutes focusing on the chaos and multiplicity of gentrification, and instead suggests a more inclusive perspective on the geography and history of gentrification. Davidson and Lees (2005) also argue for a more "elastic and targeted definition of the term" (Ibid., p. 159). Lees et al. (2008) record the key elements of gentrification as follows:

1. The reinvestment of capital

2. The social upgrading of locale by incoming high-income groups

3. Landscape change

4. Direct or indirect displacement of low-income groups

Thus, gentrification is at once an economic restructuring, a social reconfiguration, and a physical transformation which involves the displacement of original residents via teneurial transformation and economic or cultural constraints.

While some scholars focus on the meaning of the term, others focus on the causes and consequences of the process. Having operationalized the definition, the next section presents prominent explanations for the process.

\subsubsection{Explanations for gentrification}

Central to the definitional debate has been the question of whether the definition should revolve around the causes or consequences of gentrification (Brown-Saracino, 
2010, 13). Causal definitions (Production-side explanations) are rooted in classical economic theory with a Marxian interpretation of capitalism. Gentrification is seen as a result of capital switching between different sectors and parts of the city and as a product of a new international division of labor lubricated by the flows of finance capital (Harvey, 1978, 1982).

Heavily influenced by the works of Karl Marx, David Ricardo (1817), and Adam Smith (1776), Neil Smith (1979) presents one of the most influential (and heavily debated) explanations for gentrification in what he refers to as the rent gap hypothesis. He defines the rent gap as "the disparity between the potential ground rent level and the actual ground rent capitalized under the present land use" (p. 545).

When a parcel of land is initially developed, there is an effort to maximize profitability so that nearly all of its full potential is realized. As such, initial development "succeeds in capitalizing nearly all of the full potential" (Lees et al., 2008, p. 52). Over time, as the building or structure depreciates due to normal decay and wear-and-tear, its value experiences a steady decline. Routine improvements and maintenance of the built structure can slow down the aging process, however, the structure will continue to decline in value as it falls farther below the highest and best use for the location (Ibid.).

Over time, as depreciation of existing building structures occurs, there is a widening gap between capitalized ground rent (i.e., the rent based on its current use) and potential ground rent (i.e., the rent based on its potential use). The depreciation of the building results in a reduction in the amount of ground rent that can be capitalized (Smith, 1979). The potential economic return keeps in pace with regional growth, 
economic development, and technological change, thereby widening the rent gap. Stated differently, the rent gap (as shown in Figure 1) is the difference between the actual economic return given the present land use and the potential economic return from the parcel's highest and best use. It is important to return to the concept of profit. The rent gap produces conditions in which profitable reinvestment can occur in the form of gentrification (Smith, 1979).

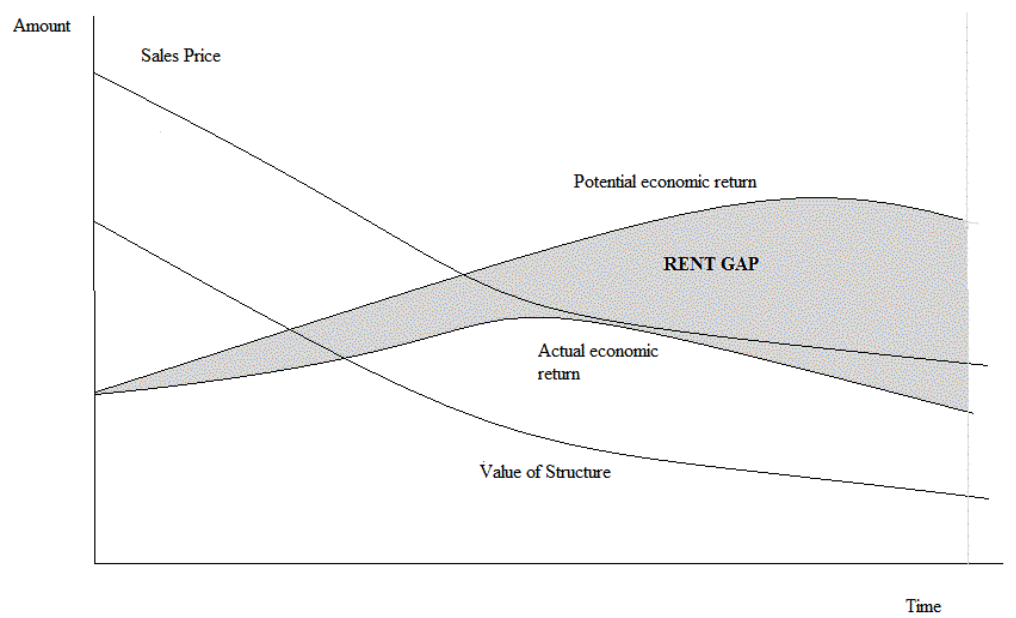

Figure 1. Rent Gap (adapted from Lees et al., 2008)

The rent gap is based on the capitalist cycles of investment and disinvestment in the urban land markets. Disinvestment occurs as investors pour capital into new development, such as the expansion of suburbs. This is sometimes accompanied by under-maintenance of the built structures near the CBD. As the rent gap increases in size due to disinvestment and depreciation, the land becomes valuable for investment via a change in land-use, for example, working-class residential to middle- or upper-class residential (Lees et al., 2008, p 52). Thus, "the rent gap explains gentrification as the 
product of investment and disinvestment in the urban land market...[it] is one way of closing the rent gap [through reinvestment]" (Ibid., 61).

The rent gap theory is one of the most debated theories in gentrification literature. Lees et al. (2010, p. 82-83) outline three main points of contention. First, there has been substantial debate about the terminology used to describe the rent gap (Bourassa, 1993; Hamnett, 1984; Clark, 1988). Second, scholars have argued that the rent gap cannot be measured empirically (for empirical examples, see Ley, 1986; Smith, 1996a; Smith and DeFilippis, 1999; Hackworth, 2002b; and Hamnett, 2003b). Third, the implicit favoring of structure over agency is the cause of much dialogue and criticism (Hamnett, 1991; Ley, 1987).

On the other hand, definitions focusing on the effects of gentrification hinge on consumption-side explanations. Consumption-side explanations underscore the effects of deindustrialization and the formation of a "new cultural class" with anti-suburban sentiments and a penchant for the amenities of urban living. This analysis is rooted in questions regarding the identities, behaviors, and ideologies of gentrifiers. While structural Marxist production-side explanations stress the role of capital and profitability, liberal humanists offering consumption-side explanations stress the role of human agency, choice, culture, and consumer demand (Hamnett, 1991).

Consumption-side theorists try to answer questions regarding the identities of the gentrifiers: who they are, where they come from, why they choose to locate in previously disinvested neighborhoods. Focusing on issues of class, culture, and aesthetics, 
consumption-side explanations revolve around individual agency and seek to understand the behaviors and consumption patterns of gentrifiers.

Early consumption-side explanations revolve around the formation of a new middle class. Challenging Marxist theories of societal development, Daniel Bell (1973) argues that as the economy of many capitalist cities shifted from manufacturing jobs to service sectors jobs, there was a rapid rise in the number of middle class professionals. The consumption patterns of such a "post-industrial society" were driven more by consumer culture than media, corporations, or government.

Influenced heavily by Daniel Bell's post-industrial thesis, David Ley (1972 onwards) advances a postindustrial thesis on gentrification. Using Canadian cities as his basis for research, Ley called the expanding middle class a "cultural new class" whose consumption patterns could not be explained by the economic functioning of housing market dynamics alone. According to Ley (1996) "the convergence of rapid economic expansion, the specific growth of white-collar professional jobs, and the maturation of the demographic bulge of the baby boom, all conspired to create a demand surge for housing among the middle class" (p. 7). Ley describes how "for a particular fragment of the middle class [the inner-city home] is an integral part of their identity formation" (Ibid.). For Ley, the explanation of gentrification was intimately tied to the reform-era urban politics of gentrifiers. Focusing on Toronto, Montreal, and Vancouver, Ley (1994) showed how the new cultural class displayed left-liberal ideology and a rejection of "political conservatism, modernist planning, and suburban ideologies" (Lees et al., 2008, p. 96). 
Critical of Neil Smith's rent gap thesis and Saskia Sassen's (1991) polarization thesis, which stated that there was a growing socioeconomic polarization between the top and the bottom echelons, Hamnett (1991) took Ley's work a step further and developed the professionalization thesis. He argues that gentrifiers are professional and managerial workers. Focusing on London (as Sassen's research did), Hamnett argues that an increase in purchasing power results in increased demand-side forces in the housing market as gentrifiers seek reduced commuting time and greater cultural and social venues available through inner-city living.

Also focusing on Canadian cities, John Caulfied (1989) argues that the new middle class rejected homogenous, mundane suburbia and developed an appetite for center-city living. Describing a cultural shift, Zukin (1991) identifies potential gentrifiers as representing "a 'reflexive' consumption that is based on higher education and related expansion of consumers of both high culture and trendy style" (p. 187).

The production-side and consumption-side explanations are usually seen as competing, but Hamnett (1991) states that "like Aesop's fable of the blind men and the elephant, each of the major theories has perceived only part of the elephant of gentrification" (p. 175). In order to gain a more holistic view, it is important to situate the concept within a historical context.

\subsubsection{Historical context}

The past fifty years have seen an evolution not only in the meaning of gentrification, but in the very nature of the process. Hackworth and Smith (2001) 
demonstrate how gentrification became more than a geographic, economic, and demographic phenomenon as government policies began to take a forefront in the restructuring process. The authors provide a stage model outlining the history of gentrification and the role of government programs in facilitating the process.

The "first wave" began in the 1950s and lasted until the global economic recession of 1973. Sporadic and highly localized, gentrification was funded primarily by the public sector. The "second wave" began post-recession in the late 1970s and continued through the late 1980s. Buoyed by federal programs such as block grants and enterprise zones, cities began to play a laissez faire role, encouraging more private sector involvement. Gentrification began to be associated with cultural processes such as the 'alternative' art scene in SoHo (Zukin, 1982).

The recession of the early 1990s witnessed a slow-down of the gentrification process but was followed by a "third wave." The state became more involved than in the second wave and developers began to lead the reinvestment process. There was an intensification of the process as gentrification became linked to large-scale capital and the state began facilitating the process.

Lees et al. (2008) suggest that there exists a distinct fourth wave in the United States. The years after the 2001 recession saw an increase in the flow of capital into the real estate markets. As banks relaxed their underwriting standards, real estate became a commodity for speculation. Lees et al. (2008) state "this wave combines an intensified financialization of housing combined with the consolidation of pro-gentrification politics and polarized urban policies" (p. 179). An expansion of credit in the housing market and 
the resulting "speculative mania" fueled the growth of the "housing bubble" (Foster, 2008, p. 4). The availability of low-interest rates and more relaxed reserve requirements for banks led to a rapid increase in mortgage lending accompanied by a rapid increase in housing prices (Ibid., p. 3). At the height of the housing bubble, in 2005, "new mortgage borrowing increased by $\$ 1.1$ trillion between October and December 2005 alone, bringing outstanding mortgage debt as a whole to $\$ 8.66$ trillion, equal to 69.4 percent of the U.S. GDP” (Ibid., p. 5).

Today, gentrification is a very different process than it was before the early 1990s recession. Hackworth (2002) identifies four changes in the pattern of the process. First, instead of sporadic, localized gentrification pioneered by artists and gays, today's gentrification is initiated by corporate developers. While corporate involvement occurred during later stages of the process, today, gentrification is becoming more and more a developer-driven process. The "pioneers" are no longer individuals but instead, large scale corporations.

Second, local and federal intervention has become "more open and assertive than before" (Hackworth, 2002, p. 818). During the 1960s, the state could not openly support gentrification and the resulting displacement due to a form of Keynesian welfare governance. This was followed by a laissez-faire urban governance period in the 1970 s and relatively indirect involvement in the 1980s. As cities began to rely more heavily on tax revenues and less federal support, the recession in the early 1990s was followed by substantially more direct state involvement (Ibid.). 
Third, opposition and resistance movements have become marginalized- a far cry from the Tompkins Square riots of 1988. Hackworth and Smith (2001) argue that "effective resistance to gentrification has declined" (p. 468). Lees et al. (2008) and Watt (2009) agree that gentrification resistance has waned, but argue that it still exists.

Finally, there has been a change in the land economics that produced earlier waves of the process due to gentrification becoming diffused into more remote neighborhoods. Reinvestment in the core increases the economic potential of adjacent parcels. This results in speculation as real estate begins to be viewed primarily as a commodity from which to gain profit. Such speculative investment eventually led to the bursting of the housing bubble in 2007, leading to a global financial crisis from 2007 to 2010. The next section looks at the roles played by elite interests and speculators as they shape the process of gentrification.

\subsection{Actors}

When Ruth Glass coined the term gentrification, she was describing a process in which the main actors were middle class to upper middle class immigrants to a disinvested neighborhood. The past fifty years have witnessed a transformation of the very structure of the process. Today, key actors include city governments, corporations, and developers intent on "rejuvenating" the city and making a profit, either directly or through tax receipts. Once a sporadic, unsystematic process, gentrification has become a methodical, planned agenda. 
The transformed role of the state, the incursion of global capital, and a waning of oppositional forces has made gentrification today an inherently different process. Gentrification is no longer "something that happens." It is a planned, coordinated process that is profitable to elites. The next section looks at the role of the various actors and the intersection of political, economic, and social dimensions.

\subsubsection{Political dimension - changing role of the state}

In order to provide a historical context, this section begins with President Lyndon Johnson's War on Poverty campaign, which led to the passing of the Economic Opportunity Act by the United States Congress in 1964. During the 1960s, the federal government launched a series of anti-poverty programs, one of the most notable being the 1966 Demonstration Cities and Metropolitan Act, i.e. the Model Cities Program. Under President Johnson, the Model Cities Program originated as a response to disillusionment with the bureaucracy associated with preceding Great Society programs geared toward eliminating poverty and racial injustice. In the War on Poverty, President Johnson asserted that the goal of the program was "to build not just housing units, but neighborhoods, not just to construct schools, but to educate children, not just to raise income, but to create beauty and end the poisoning of our environment" (Patterson, 1971, p. 17).

In a federal initiative to "improve livelihoods in American cities by channeling federal funding into their most blighted neighborhoods" (Schechter, 2011, p. 1), the program was a two-level place-based strategy that lasted until 1974. First, the program 
selected 150 cities nationwide to receive funding. Second, each of the selected cities was required to select a particular ("model") neighborhood area to which to direct all its federal funding. The Department of Housing and Urban Development developed a selection process by which to rate cities and select those most likely to provide successful results with their funding (Ibid.). The program's initial goals emphasized comprehensive planning, involving rebuilding and rehabilitation; social service delivery; and citizen participation (Waldhorn and Waldhorn, 1972).

Utilizing decennial U.S. Census Bureau data, Schechter (2011, p. 2) finds that the program "had very little impact on its targeted areas...[however], the program did reduce outmigration from the most blighted areas of target cities, when compared to cities that did not receive funding." Harrison (1973) also found that the program was not as effective as it should have been. According to him,

"once again, the urban poor have not received as large a share as might have been possible of the benefits associated with a government program ostensibly directed to improving their welfare. This 'leakage' of public anti-poverty resources into the hands of individuals at least some of whom are of doubtful standing as proper recipients has characterized other federal programs. It is unfortunate that Model Cities appears to have begun its career in a similar way" (Ibid., p. 54).

The Model Cities program was eventually folded into the new Community Development Block Grant (CDBG) program in the early 1970s. CDBG program's focus was on redevelopment of existing neighborhoods, rather than the demolition of rundown buildings in disinvested neighborhoods (Schechter, 2011). The 1980s and 1990s saw many disagreements over the outcomes of the War on Poverty and Great Society programs. The most seminal 'nail in the coffin' may have been President Raegan's final 
State of the Union address in 1988, when he declared that in America's War on Poverty, "poverty won" (Germany, 2004).

Currently, revitalization of urban neighborhoods is characterized as a combination of renovation, demolition, and economic development in the form of commercial and residential development. Today, the state's role as regulator for economic growth has shifted to progenitor of economic development. Hackworth (2002) suggests that "state involvement...[has] become more direct recently, after a period of relatively indirect involvement during the 1980s" (p. 821). This involvement has occurred in the form of national urban policy as well as "municipal entrepreneurialism" (Hackworth, 2002, p. $822)$.

National urban policy, such as the Department of Housing and Urban Development's HOPE VI program provides grants to local housing authorities to demolish "severely distressed" public housing complexes and replace them with mixeduse developments. Since its implementation, Wyly and Hammel $(1999,2000)$ found that many of the grants under the HOPE VI program are geared toward public housing complexes in or near gentrified neighborhoods. Hackworth (2002) notes that HOPE VI is part of a larger restructuring of the American state - a shift from a Keynesian form of regulation to neoliberalism. In the case of HOPE VI, the restructuring of the state has enabled local development authorities to demolish public housing without having to provide full replacement - a crucial requirement during the 1980s and early 1990s (Hackworth, 2002). This dilution of regulation creates an impetus for gentrification as middle-income residences replace low-income housing. 
At the local level, the changed role of the state combined with the functioning of global markets has created a shift toward entrepreneurial governance. With fewer outlays from the federal and state governments, cities are in a perpetual struggle to cut costs and raise tax revenues. Forced to compete in a global economy with the constant ambition of becoming a global city or being recognized as a player within a global hierarchy has put additional pressures on city officials. While cities compete with one another, they also compete with their suburban areas for tax revenues. As sprawl took a hold of most cities, their urban cores began losing population, and therefore, tax revenues. Hence, not only do cities feel outward pressure from other cities, they also feel inward pressure from their growing suburbs (Rusk, 1993).

A shift away from Keynesian governance has enabled cities to more openly assemble with real estate capital to facilitate growth (Hackworth, 2002; Smith, 2002). This manifests itself in developers playing a pioneering role in the gentrification process with open state support via tools such as tax subsidies and public-private partnerships.

More importantly, the local state takes a subordinate role to the market, making it "a junior if highly active partner to global capital" (Smith, 2002, p. 428). The focus is no longer on regulating and directing development; it is on letting market-forces dictate the trajectory of development with the local state playing a subordinate role. As the definition of the urban scale has shifted to a global scope, cities are caught in a zero-sum game (Brenner, 1998) of trying to attract capital "by offering carrots to capital while applying the stick to labor and dismantling previous supports for social reproduction" (Smith, 2002, p. 433). 
While the Keynesian city undertook social reproduction in the form of housing, welfare, and infrastructure, the neoliberal city is focused on production and finance capital at the deprivation of social reproduction. The traditional definition of Keynesianism includes greater government involvement in the form of regulation of markets, ensuring growth via full employment, with strong emphasis on aggregate demand (and therefore its regulation). Neoliberalism, on the other hand, focuses on production-side economics with a lack of government intervention in the functioning of the markets. However, in this dissertation, I argue that gentrification is a governmentdriven process in a neoliberal climate. This seeming contradiction needs further explanation.

In today's capitalist economy, the dominance of finance capital and the changing definition of geographic scale due to globalization have "reframed...territorially rooted economic actors in and of the market, rather than external compliments to it" (Smith, 2002, p. 434). As Smith (2002, p 441) describes it,

\section{"Urban policy no longer aspires to guide or regulate the direction of economic growth so much as to fit itself into the grooves already established by the market in search of the highest returns, either directly or in terms of tax receipts."}

In order to receive greater tax revenues, the state has developed mechanisms to make the built environment more compliant to real-estate capital via strategies such as the deregulation of financial markets, tax increment financing districts (TIFs), and increased support for real-estate syndications, to name a few (Weber, 2002). The underlying belief is that corporate-profits are what drive economic growth. The neoliberal governance of urban development enables spatial practices to "flourish... around 
financing, constructing, destroying, and reconstructing the built environment" (Ibid., p. 533). Thus, municipal entrepreneurialism expresses itself as the state playing an active role of facilitation rather than regulation. The state supports corporate profiteering by supporting corporate-led economic development. As the focus has shifted to economic development, gentrification is seen as a competitive urban strategy in a global marketplace. With a devolution of public policy constraints on gentrification, cities have begun to actively form public-private partnerships that result in a "private-market transformation of the built environment" (Smith, 2002, p. 440).

There have been numerous studies detailing municipal-led gentrification in various parts of the globe: London (Davidson and Lees, 2005; Watt, 2009); Birmingham's Eastside (Porter and Barber, 2006); South Parkdale, Toronto (Slater, 2004); Hoogvliet, Rotterdam (Uitermark and Kleinhans, 2007); Prenzlauer Berg, Berlin (Levine, 2004). Each of these studies points to more direct and assertive state intervention in the gentrification process. Never explicitly using the term 'gentrification', policy documents avert criticism by encouraging "social mixing" through terms like "urban renaissance, urban revitalization, urban regeneration and urban sustainability" (Lees, 2008, p. 2452). As Lees (2008) astutely puts it, "It is difficult to be for gentrification, but who would oppose 'social mixing'?” (Ibid.).

In the U.K., state-led gentrification has been promoted through a mixed communities policy with the renewal of housing markets suffering from failing owneroccupied housing (Ibid.). Davidson and Lees (2005) present an account of the "new-build riverside renaissance" along the Thames (p. 1171). They describe how this development is smaller in scale when compared to the redevelopment of the Docklands in the 1980s. It 
is also privately funded and sold under the rhetoric of "defeat[ing] social exclusion and urban malaise" (Ibid.). The authors analyze the language used in policy documents prepared by the Greater London Authority (GLA, 2002; 2004) and national government urban-policy guidelines (DETR, 1999; 2000) promoting “'sustainability', 'diversity', and 'community' in the face of forces that are destroying the physical environment, causing social exclusion, fracturing communities and disrupting our sense of place" (Ibid., p. 1172). They conclude that policymakers ironically view gentrification "as a panacea for both regional and social inequalities" (Ibid., p. 1186).

Watt (2009) also presents an account of state-led gentrification in London which "exci[ses] the concepts of 'displacement' and 'working class' from the analysis" (p. 230). He details the practices of stock transfer of public housing and the New Deal for a Communities Regeneration Program in London under New Labour's 'roll-out neoliberalism' policies. He notes that,

"The contrast between the disinvested [local authority] housing stock in London and the highly valued land it sits on creates enormous capital accumulation potential - in other words what can be termed a 'stateinduced rent gap'... This process is also regarded positively in New Labour policy terms since it facilitates the transformation of council estates from being 'ghettoes' of social exclusion towards becoming socially mixed 'sustainable communities'”' (p. 235).

Focusing on 'England's second city' (Birmingham), Porter and Barber (2006) present a case study of Birmingham's Eastside using the stories of two pubs "whose fortunes are permanently re-shaped by state-led development initiatives" (p. 215). Through a narrative of the urban changes surrounding the pubs, the authors note how "deprivation and urban decline are thus depicted as an 
improper part of urban life, requiring (state-led) intervention to eradicate them from a city's image...[as] a distinct set of policy discourses renders [the] Eastside ‘ripe' for redevelopment” (Ibid., p. 222, 223).

Slater (2004) presents a case study of gentrification in South Parkdale, Toronto (Canada) where the state-led process is presented as being emancipatory. He concludes that state-led gentrification in South Parkdale is "far from an emancipatory process" (p. 303) and instead further marginalizes the vulnerable long-time residents.

Uitermark et al. (2007) present a more nuanced interpretation of state-led gentrification, focusing on Hoogvliet, Rotterdam (Netherlands). The authors note how state actors and housing associations actively pursue gentrification projects in disadvantaged neighborhoods and contend that the driving force is not a need to strengthen the local tax base or to make a profit, but instead to "[generate] social order...pacify tensions and to reduce concentrations that pose a problem for authorities" (p. 125). Looking beyond the economic dimension (housing associations are legally bound to reinvest their profits in housing for social housing policies and, unlike in the U.S., cities receive most of their funding from the national government), the authors analyze institutional dimensions that explain state-led gentrification in the Netherlands. They find that attracting the middle classes is not the goal; instead, the aim is to "civili[ze] and [control] these neighborhoods" (Ibid., p. 127). Thus, "liveability" (Ibid., p. 128) is the driving factor for state-led gentrification in the Netherlands. 
Levine (2004) studies state-led gentrification in Prenzlauer Berg in eastern Berlin since the fall of the Berlin Wall. He asserts that the case of Germany is unique given its history of a strong planning culture and less regard for private profit-making interests. He argues that while government policy has served to encourage gentrification, it has also served to mitigate the ill-effects of the process. He finds that giving weight to "community participation, local job creation, the incorporation of immigrants, and a willingness to form partnerships among churches, charities, and community-based associations organized along ethnic lines" has led to a much more balanced approach (Levine, 2004, p. 104).

In the United States, state-led gentrification has been promoted through policies that seek to deconcentrate poverty (similar to the U.K.) and improve tax bases (Lees, 2008). Highly dependent on property tax revenues, cities in the U.S. have adopted regeneration policies under the umbrella of fiscal pragmatism (Ibid.). The creation of the Federal Department of Housing and Urban Development's HOPE VI program, wherein severely distressed inner-city projects are replaced by mixed-income housing, is in reality a testament to state-led gentrification. The most notorious example is Cabrini Green in Chicago where public housing towers were replaced by luxury condos selling at a price around $\$ 400,000$ (Levine, 2004). Beauregard (1990) has studied state-led gentrification in the neighborhoods of Society Hill district and Spring Green in central Philadelphia. Lees (2008) also discusses post-Katrina New Orleans where "the aim is to lure middle-class families back into New Orleans and to build over, displace or 'culturally integrate' the African American/low-income communities" 
(p. 2454). Over time, state-led gentrification has become more pervasive in the

U.S. as cities strive to attract the middle class back to the central core under the rhetoric of creating more 'sustainable communities'.

\subsubsection{Economic dimension - the incursion of global capital}

Gentrification in the 1950s, 1960s, and 1970s was a highly regulated process that was heavily dependent upon public financing. Inner-city disinvestment necessitated dealing with questions such as those of social housing. Gotham (2005) argues that the 1949 and 1954 Housing Acts that provided federal funds for the redevelopment of blighted areas spurred the first-wave of gentrification in the U.S. Gentrification, at this time, was thought to be too risky for the private sector (Hackworth and Smith, 2001). Subsequent stages of gentrification were not as dependent on public financing and were instead funded through private-market finance capital (Smith, 2002). The third wave of gentrification saw an intensification of private-market financing while the fourth wave has witnessed what Lees et al. (2008) refer to as "financialization" of the gentrification process as mortgage lenders begin to relax underwriting standards leading to further growth of the U.S. housing bubble (for more on the financialization of urban redevelopment, see Rutland, 2010; and Leinberger, 2001). Today, gentrification is facilitated by a merging of political powers and global corporate capital. As Smith (2002, p. 443) notes,

“...gentrification as urban strategy weaves global financial markets together with large- and medium-sized real-estate developers, local merchants, and property agents with brand-name retailers, all lubricated by city and local governments for whom beneficient social outcomes are now assumed to derive from the market rather than from its regulation." 
Business interests are integrally tied to land-use decisions, especially as developers take a more prominent role in the restructuring process. Sustained support via campaign contributions ensures that systemic power rests in the hands of the business elite (Stone, 1981). Once organized, they become "mobilized interests" (Fainstein, Fainstein, and Armistead, 1983 as quoted in Logan and Molotch, 1987). Gentrification occurs as a planned agenda for profiteering under the guise of neighborhood revitalization.

Real estate speculation cannot take place without secondary actors such as lawyers, syndicators, bankers, and property brokers who facilitate the business dealings. Together, they represent corporate interests that ensure that the gentrification process takes place in a methodical manner. Local government, as a subordinate actor, further facilitates and lubricates the process through actions such as providing tax subsidies to developers or laying the necessary infrastructure or "curbing" crime and making the streets safer ('the revanchist thesis').

The lure for each actor is the profitability of the "deal." Developers and landlords earn profits directly through increased rents. Lawyers, bankers, syndicators and other corporate interests earn profits in the manner of transaction fees. And, the local government justifies profits indirectly in the form of greater tax receipts as a more affluent class replaces a lower-income tax base.

Noticeably missing from the table are the existing residents of the neighborhoods that are being revitalized. Perhaps, this is because they are the only group not making a profit. In fact, as gentrification takes a hold of the neighborhood, property values rise, 
causing the existing residents to be displaced either due to teneurial transformation (rental properties become non-rental properties), economic factors (as residents can no longer afford the increased rents), and/or cultural reasons (as social networks become weakened as a result of friends and neighbors moving out). Thus, local residents not only don't have a voice in the process of gentrification, they are also the sole losers.

\subsubsection{Social dimension - resistance movements}

But in whose image is space created? (Harvey, 1973 as quoted in Lees et al., 2008)

Appropriated space is a representation of symbolic power that creates social meaning. As power shifts from local residents into the hands of elite business interests, resistance efforts take the form of community protests. The most renowned and welldocumented resistance movement took place in a violent clash between police and protestors at Tompkins Park Square in Lower East Side in 1988. Neil Smith likens Tompkins Park to a "new urban frontier" (Smith, 1996). In one of the most intense antigentrification struggles of the 1980s, Smith (1996) recounts stories of revanchism where "it was a police riot that ignited the park on August 6, 1988" (p. 3).

Hackworth (2002) notes that anti-gentrification movements have become "more marginal than in earlier decades" (p. 818). He outlines the limited success of opposition movements during the 1970s and 1980s as working-class groups secured limited agreements from banks and developers thus making the process less damaging. An example of such a compromise can be found in the Mexican-American Pilsen 
neighborhood in Chicago's Lower West side where long-term residents were able to hang on to a prominent retail strip that catered to the needs of the long-term residents, thereby maintaining some of the cultural fabric of the neighborhood (Wilson, Wouters, and Grammenos, 2004). The 1980s witnessed a more militant form of opposition followed by a marginalization within the political realm during the 1990s.

Hackworth (2002) notes how anti-gentrification movements split into two kinds of oppositional forms (p. 823-824). On the one hand, opposition (such as the Tompkins Square riots and San Francisco's Tenderloin District protests) were violent with strong retaliation from city hall. Such movements had some success as protestors were able to secure some compromise from the local government.

On the other hand, less militant groups received more responsive treatment within the political sphere. Creative methods such as the formation of Community Development Corporations (CDCs) have facilitated dialogue between elite interests and the existing community, especially with regard to affordable housing provision. CDCs are, however, reliant on state funding, creating tangible constraints to active criticism and advocacy (for examples of rescinded funding/disciplinary action from the state, see cases of Pratt Area CDC and Oceanhill Brownsville Tenants Association, both in Brooklyn (Hackworth, 2002, p. 824)).

Scholars contend that the reason for diminished resistance to gentrification is twofold. First, continued displacement results in a weakening of the core group of activists (Hackworth, 2002; Fainstein and Fainstein, 1991). Second, coordination and implementation of community organizing is increasingly difficult in a neoliberal state (DeFilippis, 2004; Newman and Lake, 2006; Lees et al., 2008). However, as Lees et al. 
(2008 and 2010) and Watts (2009) point out, resistance movements, while not as overt, still exist in many communities.

In his essay, The Right to Stay Put, Hartman (1984) suggests that "carefully prepared publicity and organizing campaigns can be important building blocks toward political and legal acceptance of a right to housing" (original emphasis) (p. 318). He explains how the right to stay put is "in the public interest" as the social costs of displacement outweigh the societal benefits. The next section takes a look at the neighborhood effects of gentrification and its associated costs and benefits.

\subsection{Costs and Benefits of Gentrification}

Gentrification has both positive and negative impacts on the neighborhood being gentrified. Proponents argue that it creates a more mixed, stable community that can lead cities back to fiscal health. Officials discuss benefits such as increased employment due to new construction; rehabilitation of existing housing stock; cleaner, safer communities; and increased property values (Lang, 1986). Opponents contend that it erodes the very fabric of the existing community through displacement. Additionally, the very essence of the neighborhood changes as the existing community is displaced by middle income tastes and values (Ibid.). Table 1 highlights some costs and benefits of the gentrification process and the following sections present a discussion of both sides in greater detail. 
Table 1. Costs and Benefits of Gentrification (Atkinson, 2002)

\begin{tabular}{|l|l|}
\hline Costs & Benefits \\
\hline Infrastructure outlays & Property tax revenues increase \\
\hline Developer subsidies & Wage tax revenues increase \\
\hline Increased law enforcement & Parking revenues increase \\
\hline $\begin{array}{l}\text { Increased costs for municipal services } \\
\text { (sewer, utilities etc.) }\end{array}$ & Business tax revenues increase \\
\hline $\begin{array}{l}\text { Out-migration facilitated by Section } 8 \\
\text { restructuring [OTR] }\end{array}$ & License/Permit fees \\
\hline Impaction Ordinance [OTR] & Beautification \\
\hline Displacement through rent/price increases & \\
\hline Loss of social capital & \\
\hline Community tensions & Valorization of disinvested neighborhood \\
\hline Loss of affordable housing & Increased property values \\
\hline Speculative property price increases & Reduced vacancy rates \\
\hline Homelessness & Reduction of suburban sprawl \\
\hline Loss of social diversity & Increased social mix \\
\hline Increase in crime & Decrease in crime \\
\hline
\end{tabular}

\subsubsection{Costs of Gentrification}

The majority of research points to displacement as the greatest cost of gentrification (LeGates and Hartman, 1981, 1986; Lyons, 1996; Newman and Wyly, 2006). Displacement can be direct (i.e. forcible; for example, through eviction) or indirect (for example, through rent increases). There is also exclusionary displacement (Marcuse, 1985 ) as prices rise and property becomes unaffordable to low income households trying to move into the neighborhood.

Spiraling rent prices lead to direct, indirect as well as exclusionary displacement. The loss of affordable housing translates into displacement over a longer distance which then impacts travel to work distances or even the prospect of gaining employment 
(Atkinson, 2002). This further exacerbates the cycle of poverty and related pathologies as displacees are unable to secure employment.

There are quantifiable costs to displacement such as search costs and moving costs. There are also psychological costs such as the stress of moving, loss of home, loss of social networks, and loss of community. As friends and neighbors are forced to leave the neighborhood, the social fabric of the community becomes eroded, often creating resentment and hostility toward the newcomers. Paradoxically, resistance movements become weaker as the voice of the neighborhood (Chernoff, 1980) changes due to displacement of local community activists. Thus, the resulting polarization of the community also imposes societal costs.

One extreme of displacement is homelessness while the other extreme is a damaged sense of community (Marcuse, 1985). Homelessness has associated costs related to mental health, physical health, encounters with law enforcement, substance abuse and housing costs. A 2006 study by the Partnership to End Long Term Homelessness finds that the 150,000 chronically homeless people in the United States cost $\$ 10.95$ billion per year in public funds.

At best, displacement creates a damaged sense of community (Marcuse, 1985). The loss of familiar neighbors providing childcare and "looking out" for one another is a tangible and often irreplaceable cost. Not only is it a deeply private loss, the loss of community is also a palpable public cost.

Although the results have been contradictory, some research suggests that crime actually increases in neighborhoods that have gentrified (Taylor and Covington, 1988; 
Covington and Taylor, 1989). Rational actor theories suggest that a greater presence of affluent households will act as targets for criminals in neighboring areas, resulting in an increase in crime (Atkinson, 2002).

While some of the costs outlined above are difficult to monetarize, there are several costs that are easier to measure. Such costs are usually borne by the city and include infrastructural outlays, changes to local service provision (water, sewer, utilities), costs of increased law enforcement, and developer subsidies.

\subsubsection{Benefits of Gentrification}

The most celebrated aspect of gentrification is urban renewal or the upgrading of a previously disinvested neighborhood. Upgrading occurs in the physical form of rehabilitated building structures, sometimes assigned a "historical home" designation. It also occurs in the form of social upgrading as a more affluent, well-educated middle class migrates to the neighborhood.

As the neighborhood becomes more socially mixed, there are trickle down effects that mitigate the negative 'neighborhood effects' of concentrated poverty. The emancipatory city thesis which describes gentrification as a unifying process creating cultural diversity, tolerance, liberation, and social interaction has been presented in the works of Ley (1980, 1994, 1996), Butler (1997), and Caulfield (1989, 1994). 
Social mixing allows people of different socioeconomic backgrounds to interact with one another, "broadening horizons and raising expectations" (Lees et al., 2008, p. 199). As Byrne (2003) states,

[gentrification] can ameliorate the social isolation of the poor. New more affluent residents will rub shoulders with poorer existing residents on the streets, in shops, and within local institutions, such as public schools...[providing] existing residents with the kind of role models and contacts the absence of which Wilson (1987) finds debilitating in the ghetto.(Byrne, 2003, p. 422 as quoted in Lees et al., 2008, p. 205)

However, Blomley (2004) argues that interaction in mixed neighborhoods is limited and can lead to social segregation and isolation. Clay (1979) also shows apprehension at the viability of a socially mixed neighborhood.

Another boon of gentrification is increased property tax revenues. As home ownership changes hands from existing residents to more affluent newcomers, improvements to the property result in property value increases which translate into higher property tax receipts to the city. Increased tax revenues are said to be a result of an increase in the number of owner-occupied households and an increase in the property value of such households. However, research finds that gentrifiers are not moving from the suburbs but instead moving within the city (Gale, 1984), thus undermining the claim of a net household gain.

The process of gentrification also has secondary benefits such as a more aesthetically pleasing neighborhood and/or a safer neighborhood due to increased police presence. Studies (Henig and Gale, 1987) have shown that existing residents also enjoy such ameliorations; however, they may be displaced in time thus not being able to fully take advantage of such improvements (Atkinson, 2002). 
Beside increases in property tax revenues, there are other measurable benefits. These include license and permit fees, increases in business tax revenues, parking revenues, and wage tax revenues.

Gentrification has costs and benefits associated with it. The active involvement of government officials, developers, and planners in promoting gentrification is rooted in the assumption that the benefits of gentrification outweigh the costs associated with it. While there have been studies focused on analyzing the costs and benefits of gentrification, such studies have focused solely on the quantifiable aspects of the process (for example, Lang, 1986). Although such analysis takes into account externalities, it can only do so in a limited capacity. For example, it cannot quantify the loss of social capital or social networks. Hence, such analysis does not present a comprehensive accounting of the process, thereby limiting the lens through which government officials evaluate revitalization projects.

This study adds to the existing literature by providing an account of the costs and benefits of the gentrification process using qualitative analysis. By gaining a more holistic view, policymakers will be better equipped to assess the merits and demerits of revitalization projects in their cities. The next chapter provides a methodological framework for this study. 


\section{CHAPTER 3}

\section{METHODS}

While quantitative analysis accounts for the cost effectiveness of city government, it can only take into account what neoclassical economics labels "externalities" up to a certain point. Again, the marginalized population is conspicuously missing from this analytical discussion. The decision metrics revolve solely around those concerned with monetary gain. Quantitative analysis simply accounts for profitability for a select group of actors - the business elite. Qualitative analysis goes one step further by providing a more holistic assessment of the social costs and benefits of a project, especially from the vantage point of those most directly involved in and affected by the gentrification process. In this study, residents' experiences and the perceptions of representatives of community organizations were examined in addition to the perceptions of city officials and developers. The next section provides some historical and demographic details on the site chosen for the case study, Over-the-Rhine.

\subsection{Over-the-Rhine (OTR)}

OTR was chosen as a case study because it represents certain universalities of a state-led gentrification process in an older city, Cincinnati (Miller and Tucker, 1998; 
Smith and Feagin, 1995). The process of gentrification in OTR has been shaped by elite interests through coordinated efforts between the city, the Cincinnati Center City Community Development Corporation (3CDC), the OTR Chamber of Commerce, and the corporate community. In an effort to "promote economic vitality," to date, 3CDC has invested over \$300 million for renovation, revitalization and redesign in OTR. 3CDC's focus on market-rate development has led to stricter police controls, resulting revanchism (reminiscent of "Operation Vortex" in the 1980s) and further marginalization of the poor and the homeless (Diskin and Dutton, 2006). Policies such as Cincinnati City Council's "Impaction Ordinance" and "Historic district designation" have reduced the affordable housing supply and put economic pressure on existing residents via building violations and fines. The restructuring of Section 8 subsidized housing vouchers has resulted in the out-migration of low-income residents, weakening the social fabric of the existing community (Addie, 2008). As state-led gentrification becomes more pervasive in OTR, an assessment of the costs and benefits of such projects becomes imperative. When viewed comprehensively, do the social benefits of urban renewal really outweigh the social costs?

\subsubsection{OTR History and Demographic Characteristics}

OTR is a neighborhood located between the Central Business District (CBD) and Uptown medical and university community in Cincinnati, Ohio (Figure 2a and 2b). Additionally, the neighborhood is bordered by the neighborhoods of Mount Auburn, Mount Adams, and the West End. Lauded as Cincinnati's oldest and most historic 
neighborhood, consisting of 943 buildings of $19^{\text {th }}$ century Italianate architecture, OTR was designated as an historic district by the National Register of Historic Places in 1983. Originally settled by German immigrants in the 1830s, the neighborhood was named in honor of the Rhine River in Germany. During the 1930s, Appalachians began to move into the neighborhood. The original German settlers moved to the suburbs, leaving behind a primarily low-income, White community. OTR experienced demographic flux again during the 1960s, when African Americans migrated to the neighborhood. Today, the neighborhood consists of a primarily low-income African American population (Over-the-Rhine Foundation; Miller and Tucker, 1998).

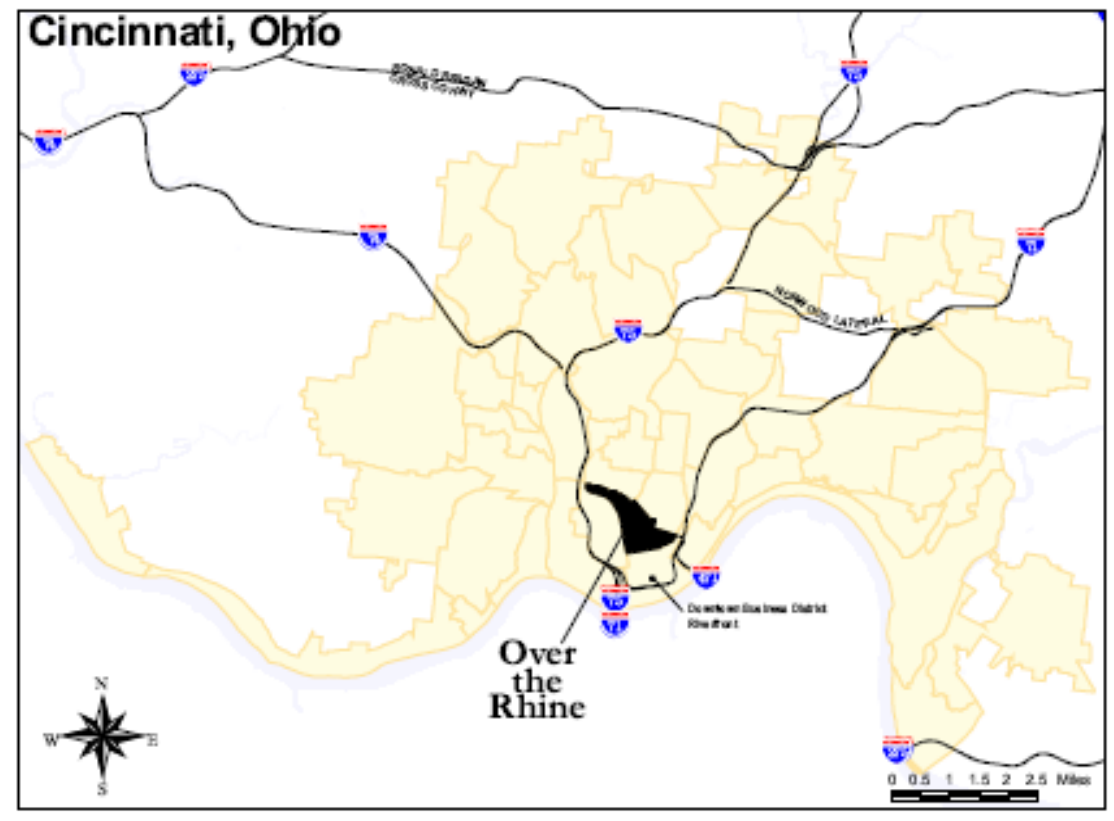

Figure 2a. Location of Over-the-Rhine in Cincinnati, Ohio (Source: Over-the-Rhine Comprehensive Plan, June 2002) 


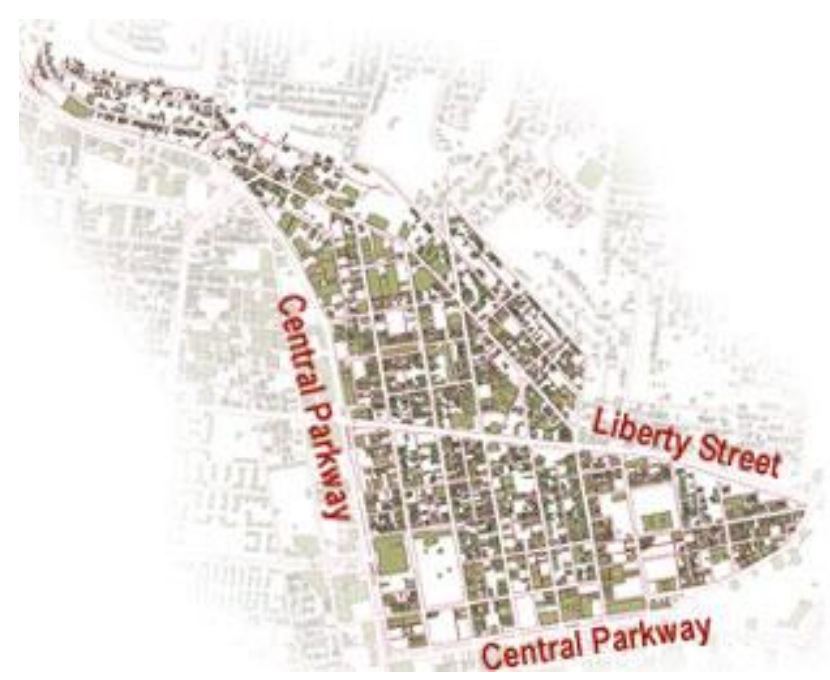

Figure 2b. The Over-the-Rhine neighborhood of Cincinnati, Ohio (Source: http://www.irhine.com/index.jsp?page=map_intro)

Spanning 362.5 acres, OTR's population has declined from 44,475 in 1900 (U.S. Census Bureau) to 4,351 residents today (U.S. Census Bureau, 2012 American Community Survey 5 year estimates). In 2012, the population in OTR was 4,351 individuals, categorized as 33\% Caucasian (1454 residents), 61\% African American (2640 residents), and 6\% other races (257 residents) (Table 2). The demographics over the past twelve years have changed substantially, when in 2000 , the population was 7,638 individuals, categorized as 19\% Caucasian (1482 residents), 77\% African American (5876 residents), and 4\% other races (280 residents) (Table 3). 
Table 2. Demographics of Over-the-Rhine in 2012

\begin{tabular}{|c|c|c|c|c|c|c|c|}
\hline CENSUS TRACT & $\begin{array}{l}\text { TOTAL } \\
\text { POP }\end{array}$ & WHITE & $\begin{array}{l}\% \\
\text { WHITE }\end{array}$ & BLACK & $\begin{array}{l}\% \\
\text { BLACK }\end{array}$ & OTHER & $\begin{array}{l}\% \\
\text { OTHER }\end{array}$ \\
\hline Census Tract 9 & 855 & 364 & $42.57 \%$ & 463 & $54.15 \%$ & 28 & $3.27 \%$ \\
\hline Census Tract 10 & 993 & 613 & $61.73 \%$ & 337 & $33.94 \%$ & 43 & $4.33 \%$ \\
\hline Census Tract 11 & 862 & 133 & $15.43 \%$ & 727 & $84.34 \%$ & 2 & $0.23 \%$ \\
\hline Census Tract 16 & 914 & 245 & $26.81 \%$ & 664 & $72.65 \%$ & 5 & $0.55 \%$ \\
\hline Census Tract 17 & 727 & 99 & $13.62 \%$ & 449 & $61.76 \%$ & 179 & $24.62 \%$ \\
\hline Total & 4351 & 1454 & $33.42 \%$ & 2640 & $60.68 \%$ & 257 & $5.91 \%$ \\
\hline Source: 2012 ACS & estimates & & & & & & \\
\hline
\end{tabular}

Table 3. Demographics of Over-the-Rhine in 2000

\begin{tabular}{|c|c|c|c|c|c|c|c|}
\hline CENSUS TRACT & $\begin{array}{l}\text { TOTAL } \\
\text { POP }\end{array}$ & WHITE & $\begin{array}{l}\% \\
\text { WHITE }\end{array}$ & BLACK & $\begin{array}{l}\% \\
\text { BLACK }\end{array}$ & OTHER & $\begin{array}{l}\% \\
\text { OTHER }\end{array}$ \\
\hline Census Tract 9 & 2070 & 505 & $24.40 \%$ & 1469 & $70.97 \%$ & 96 & $4.64 \%$ \\
\hline Census Tract 10 & 1357 & 384 & $28.30 \%$ & 921 & $67.87 \%$ & 52 & $3.83 \%$ \\
\hline Census Tract 11 & 1141 & 166 & $14.55 \%$ & 943 & $82.65 \%$ & 32 & $2.80 \%$ \\
\hline Census Tract 16 & 1712 & 213 & $12.44 \%$ & 1437 & $83.94 \%$ & 62 & $3.62 \%$ \\
\hline Census Tract 17 & 1358 & 214 & $15.76 \%$ & 1106 & $81.44 \%$ & 38 & $2.80 \%$ \\
\hline Total & 7638 & 1482 & $19.40 \%$ & 5876 & $76.93 \%$ & 280 & $3.67 \%$ \\
\hline \multicolumn{3}{|c|}{ Source: 2000 ACS Summary File Estimates } & & & & & \\
\hline
\end{tabular}

According to the 2008-2012 American Community Survey 5-Year Estimates, the five census tracts (census tracts 9-11, 16, and 17) comprising OTR have 5,369 housing units. Of the 5,369 housing units, $62.8 \%$ (3,321 units) remain vacant while $37.2 \%(1,966$ units) are occupied. Of the occupied households, 12.2\% (239 units) are owner occupied while $87.8 \%$ (1,727 units) are renter occupied (Table 4). 98.1\% (4,611 units) of the household units were built prior to 1939 and $1.9 \%$ (90 units) were built since 2000 . 
Table 4. Housing Indicators in Over-the-Rhine

\begin{tabular}{|l|l|l|}
\hline & Number of Units & Percentage of Total \\
\hline Vacant & 3,321 & 62.8 \\
\hline Occupied & 1,966 & 37.2 \\
\hline Owner Occupied & 239 & 12.2 \\
\hline Renter Occupied & 1,727 & 87.8 \\
\hline Total & 5,369 & 100 \\
\hline
\end{tabular}

(Source: 2008-2012 American Community Survey 5-Year Estimates)

Of the 1,966 households, the average median household income for the five census tracts in 2012 inflation-adjusted dollars is $\$ 17,895$ and the per capita income is $\$ 18,399$. Of the persons for whom poverty status is determined, $55.2 \%$ earned income below the poverty level in the prior 12 months (2008-2012 American Community Survey 5-Year Estimates).

Of the 1,966 occupied households, the total population in those households equals 3,882 individuals. Households with families equal 37.2\% (732 households), and family households, those with their own children under 18 years of age, equal 28.2\% (554 units). Married couple households equal $7.6 \%$ while those with own children under 18 years of age total 3.5\%. Male headed family households equal $5.1 \%$ and male headed households with own children under 18 years of age equal $3 \%$. Somewhat expectedly, there is a disproportionate number of female headed family households, totaling $24.5 \%$, in the disinvested neighborhood. Female headed households with their own children under 18 years of age equal $21.7 \%$ (Table 5a.1 and 5a.2).

Of the five census tracts comprising OTR, $27.4 \%$ of households are located within tract 10 . The remaining four tracts, each contains approximately $17 \%-19 \%$ of households. Tract 11 houses the largest number of family households (53.3\%) as well as the largest 
number of family households with own children under the age of $18(43.5 \%)$. Tract 11 also houses the largest number of married-couple family households $(9.2 \%)$, followed by tract $10(8.3 \%)$, tract 9 and 16 (both at $6.8 \%)$, and tract $17(6.5 \%)$, respectively. Interestingly, tract 11 also houses the largest number of married couple families with own children under the age of $18(5.7 \%)$, the largest number of male headed family households at $10.3 \%$, and the largest number of male headed households with own children under the age of $18(7.1 \%)$. Tract 16 contains the lowest number of male headed households at $1.4 \%$. Tracts 16,17 , and 11 contain the largest number of female headed households at $35.1 \%, 34.8 \%$, and $33.7 \%$, respectively. Tracts 9 and 10 contain a substantially lower number of female headed households at $14.8 \%$ and $10.9 \%$, respectively. It is interesting to note that there are no households with married-couple families with their own children under 18 years of age located in census tracts 9 and 17 . Also, there are no male headed households with their own children under 18 years located in census tracts 9 and 16. 
Table 5a.1. Household Statistics in Over-the-Rhine

\begin{tabular}{|l|r|r|r|r|r|r|r|r|r|r|r|}
\hline & & & & & & & & & & & \\
\hline
\end{tabular}

Table 5a.2. Household Statistics in Over-the-Rhine

\begin{tabular}{|c|c|c|c|c|c|c|c|c|}
\hline $\begin{array}{l}\text { CENSUS } \\
\text { TRACT }\end{array}$ & $\begin{array}{l}\text { Family } \\
\text { household } \\
\text { s-Male } \\
\text { household } \\
\text { er, no wife } \\
\text { present, } \\
\text { family }\end{array}$ & $\begin{array}{l}\% \\
\text { Family } \\
\text { household } \\
\text { s-Male } \\
\text { household } \\
\text { er, no wife } \\
\text { present, } \\
\text { family }\end{array}$ & $\begin{array}{l}\text { Male } \\
\text { household } \\
\text { er, no wife } \\
\text { present- } \\
\text { With own } \\
\text { children } \\
\text { under } 18 \\
\text { years }\end{array}$ & $\begin{array}{l}\% \\
\text { Male } \\
\text { household } \\
\text { er, no wife } \\
\text { present- } \\
\text { With own } \\
\text { children } \\
\text { under } 18 \\
\text { years }\end{array}$ & $\begin{array}{l}\text { Female } \\
\text { household } \\
\text { er, no } \\
\text { husband } \\
\text { present, } \\
\text { family }\end{array}$ & $\begin{array}{l}\% \\
\text { Female } \\
\text { household } \\
\text { er, no } \\
\text { husband } \\
\text { present, } \\
\text { family }\end{array}$ & $\begin{array}{l}\text { Female } \\
\text { household } \\
\text { er, no } \\
\text { husband } \\
\text { present- } \\
\text { With own } \\
\text { children } \\
\text { under } 18 \\
\text { years }\end{array}$ & $\begin{array}{l}\% \\
\text { Female } \\
\text { household } \\
\text { er, no } \\
\text { husband } \\
\text { present- } \\
\text { With own } \\
\text { children } \\
\text { under } 18 \\
\text { years }\end{array}$ \\
\hline $\begin{array}{l}\text { Census Tract } \\
9\end{array}$ & 13 & 3.7 & 0 & 0.0 & 52 & 14.8 & 52 & 14.8 \\
\hline $\begin{array}{l}\text { Census Tract } \\
10\end{array}$ & 27 & 5.0 & 15 & 2.8 & 59 & 10.9 & 45 & 8.3 \\
\hline $\begin{array}{l}\text { Census Tract } \\
11\end{array}$ & 38 & 10.3 & 26 & 7.1 & 124 & 33.7 & 113 & 30.7 \\
\hline $\begin{array}{l}\text { Census Tract } \\
16\end{array}$ & 5 & 1.4 & 0 & 0.0 & 129 & 35.1 & 99 & 26.9 \\
\hline $\begin{array}{l}\text { Census Tract } \\
17\end{array}$ & 17 & 5.0 & 17 & 5.0 & 118 & 34.8 & 118 & 34.8 \\
\hline & 100 & 5.1 & 58 & 3.0 & 482 & 24.5 & 427 & 21.7 \\
\hline Source: 2012 & rear & & & & & & & \\
\hline
\end{tabular}


According to the 2012 American Community Survey 5 year estimates, there are a total of $62.8 \%$ (1234 units) that are considered "non-family" households. Of those nonfamily households, $8.3 \%$ (102 units) are occupied by those 65 years and over, living alone (Table 5b). Of all occupied 1,966 units, the average household size is 2, while the average family size is 2.93 individuals (Table $5 \mathrm{c}$ ).

Table 5b. Household Statistics in Over-the-Rhine

\begin{tabular}{|l|r|l|}
\hline & & \multicolumn{2}{|l|}{$\begin{array}{l}\text { Nonfamily households - } \\
\text { Householder living alone - } \\
\text { CENSUS TRACT }\end{array}$} & Nonfamily households & \begin{tabular}{l} 
65 and over \\
\hline Census Tract 9
\end{tabular} 263 & 21 \\
\hline Census Tract 10 & 408 & 32 \\
\hline Census Tract 11 & 172 & 27 \\
\hline Census Tract 16 & 209 & 20 \\
\hline Census Tract 17 & 182 & 2 \\
\hline Total & $\mathbf{1 2 3 4}$ & $\mathbf{1 0 2}$ \\
\hline Source: 2012 ACS 5 year estimates & \\
\hline
\end{tabular}

Table 5c. Household Statistics in Over-the-Rhine

\begin{tabular}{|c|c|c|}
\hline CENSUS TRACT & $\begin{array}{l}\text { Average } \\
\text { household } \\
\text { size }\end{array}$ & $\begin{array}{l}\text { Average } \\
\text { family size }\end{array}$ \\
\hline Census Tract 9 & 1.46 & 2.21 \\
\hline Census Tract 10 & 1.68 & 3.02 \\
\hline Census Tract 11 & 2.32 & 3.28 \\
\hline Census Tract 16 & 2.4 & 2.99 \\
\hline Census Tract 17 & 2.14 & 3.15 \\
\hline Average & 2 & 2.93 \\
\hline
\end{tabular}


A total of 1,243 individuals above the age of 3 are enrolled in school, while a total of 432 individuals are enrolled in college or graduate school. A total of 2,627 individuals, 25 years and over, have some form of educational attainment. Table 6 provides further details, with the largest segment of the population (27.7\% or 728 individuals) having a high school diploma or equivalency, followed by those having received education until the $12^{\text {th }}$ grade (15.3\% or 403 individuals), however, not having received a diploma. 3.3\% (87 individuals) have an educational attainment of less than $9^{\text {th }}$ grade. $15 \%$ (395 individuals) have a Bachelors degree and 14.8\% (390 individuals) have a graduate or professional degree, while 4.7\% (123 individuals) have an Associate's degree. The category "some college, no degree" is not reported. Therefore, the aggregate of the categorical educational attainment numbers does not equal the total for population 25 and over.

Next, looking at the data in further detail as a percentage of "Educational attainment, population 25 and over," of the 87 individuals with an educational attainment of less than $9^{\text {th }}$ grade, $6.6 \%$ live in census tract 9 , followed by $5.7 \%$ in tract $16,1.6 \%$ in tract $10,1.1 \%$ in tract 11 , and $0.5 \%$ in tract 17 , respectively. Of the 403 individuals who received education until the $12^{\text {th }}$ grade but did not receive a diploma, majority of them (35.9\% or 142 individuals) live in tract 17, making them the highest demographic population within that tract. Tract 11 houses majority of the population with an Associate's degree (9.0\%), while tract 10 houses a majority of those with a Bachelor's degree (27.6\%). Those with graduate or professional degrees reside primarily in tract 16 $(26.8 \%)$. 
Table 6. Educational Enrollment and Attainment in Over-the-Rhine

\begin{tabular}{|c|c|c|c|c|c|c|c|c|c|c|c|c|c|c|c|}
\hline $\begin{array}{l}\text { CENSUS } \\
\text { TRACT } \\
\end{array}$ & $\begin{array}{l}\text { Populatit } \\
\text { on } 3 \\
\text { years } \\
\text { and over } \\
\text { enrolled } \\
\text { in } \\
\text { school }\end{array}$ & $\begin{array}{l}\text { Colleg } \\
\text { e or } \\
\text { gradua } \\
\text { te } \\
\text { school } \\
\text { enroll } \\
\text { ment }\end{array}$ & $\begin{array}{l}\text { Educati } \\
\text { onal } \\
\text { Attainm } \\
\text { ent- } \\
\text { Populati } \\
\text { on } 25 \\
\text { years } \\
\text { and } \\
\text { over } \\
\end{array}$ & $\begin{array}{l}\text { Educat } \\
\text { ional } \\
\text { Attain } \\
\text { ment- } \\
\text { Less } \\
\text { than } \\
\text { 9th } \\
\text { grade }\end{array}$ & $\begin{array}{l}\% \\
\text { Educati } \\
\text { onal } \\
\text { Attain } \\
\text { ment- } \\
\text { Less } \\
\text { than } \\
\text { 9th } \\
\text { grade }\end{array}$ & $\begin{array}{l}\text { Educati } \\
\text { onal } \\
\text { Attain } \\
\text { ment } \\
\text { 9th to } \\
\text { 12th } \\
\text { grade, } \\
\text { no } \\
\text { diplom } \\
\text { a } \\
\end{array}$ & $\begin{array}{l}\text { \% } \\
\text { Educati } \\
\text { onal } \\
\text { Attain } \\
\text { ment- } \\
\text { 9th to } \\
\text { 12th } \\
\text { grade, } \\
\text { no } \\
\text { diplom } \\
\text { a } \\
\end{array}$ & $\begin{array}{l}\text { Educati } \\
\text { onal } \\
\text { Attainm } \\
\text { ent- } \\
\text { High } \\
\text { school } \\
\text { graduat } \\
\mathrm{e} \\
\text { (include } \\
\mathrm{s} \\
\text { equival } \\
\text { ency) }\end{array}$ & $\begin{array}{l}\% \\
\text { Educati } \\
\text { onal } \\
\text { Attainm } \\
\text { ent- } \\
\text { High } \\
\text { school } \\
\text { graduat } \\
\text { e } \\
\text { (include } \\
\text { s } \\
\text { equival } \\
\text { ency) }\end{array}$ & $\begin{array}{l}\text { Educati } \\
\text { onal } \\
\text { Attain } \\
\text { ment- } \\
\text { Asssoci } \\
\text { ate's } \\
\text { degree }\end{array}$ & $\begin{array}{l}\% \\
\text { Educati } \\
\text { onal } \\
\text { Attain } \\
\text { ment-- } \\
\text { Assoos } \\
\text { ate's } \\
\text { degree }\end{array}$ & $\begin{array}{l}\text { Educati } \\
\text { onal } \\
\text { Attain } \\
\text { ment- } \\
\text { Bachel } \\
\text { or's } \\
\text { degree }\end{array}$ & $\begin{array}{l}\% \\
\text { Educati } \\
\text { onal } \\
\text { Attain } \\
\text { ment-- } \\
\text { Bachel } \\
\text { or's } \\
\text { degree }\end{array}$ & $\begin{array}{l}\text { Educati } \\
\text { onal } \\
\text { Attain } \\
\text { ment- } \\
\text { Gradua } \\
\text { te or } \\
\text { professi } \\
\text { onal } \\
\text { degree } \\
\end{array}$ & $\begin{array}{l}\% \\
\text { Educati } \\
\text { onal } \\
\text { Attain } \\
\text { ment- } \\
\text { Gradua } \\
\text { te or } \\
\text { professi } \\
\text { onal } \\
\text { degree }\end{array}$ \\
\hline $\begin{array}{l}\text { Census } \\
\text { Tract } 9\end{array}$ & 159 & 69 & 618 & 41 & 6.6 & 52 & 8.4 & 294 & 47.6 & 14 & 2.3 & 81 & 13.1 & 43 & 7.0 \\
\hline $\begin{array}{l}\text { Census } \\
\text { Tract } 10\end{array}$ & 254 & 131 & 677 & 11 & 1.6 & 46 & 6.8 & 134 & 19.8 & 53 & 7.8 & 187 & 27.6 & 111 & 16.4 \\
\hline $\begin{array}{l}\text { Census } \\
\text { Tract } 11\end{array}$ & 306 & 50 & 443 & 5 & 1.1 & 69 & 15.6 & 148 & 33.4 & 40 & 9.0 & 45 & 10.2 & 63 & 14.2 \\
\hline $\begin{array}{l}\text { Census } \\
\text { Tract } 16\end{array}$ & 297 & 118 & 493 & 28 & 5.7 & 94 & 19.1 & 79 & 16.0 & 6 & 1.2 & 26 & 5.3 & 132 & 26.8 \\
\hline $\begin{array}{l}\text { Census } \\
\text { Tract } 17 \\
\end{array}$ & 227 & 64 & 396 & 2 & 0.5 & 142 & 35.9 & 73 & 18.4 & 10 & 2.5 & 56 & 14.1 & 41 & 10.4 \\
\hline Total & 1243 & 432 & 2627 & 87 & 3.3 & 403 & 15.3 & 728 & 27.7 & 123 & 4.7 & 395 & 15.0 & 390 & 14.8 \\
\hline $\begin{array}{l}\text { Source: } 2 \\
\text { estimates }\end{array}$ & $\mathrm{CS}$ & & & & & & & & & & & & & & \\
\hline
\end{tabular}

It is interesting to take a closer look at median earnings by educational attainment (Table 7). The less than high school graduates, majority of whom live in census tract 9, earned the lowest income $(\$ 4,583)$ in OTR. The highest income $(\$ 114,097)$ is earned by those with a Bachelor's degree, living in census tract 11 . However, those with a Bachelor's degree, living in tract 17 , earned the second-lowest income $(\$ 4,769)$ in OTR. While data for median income for less than high school graduates was not available, tract 17 seems to have the lowest aggregate earnings. Interestingly, those with a graduate or professional degree living in tract 17 also earned the second-lowest income $(\$ 39,659)$ within their cohort. Tract 17 is somewhat of an anomaly, given that those with Associate's degrees also earned the lowest income within their cohort. There could be a few potential explanations for the inconsistency. Those with advanced degrees earning lower income and living in tract 17 may be students or those employed in lower paying professions. For instance, Miami University’s Center for Community Engagement, 
located in OTR, provides a residency program as part of the curriculum. Students "integrate academics with a full immersion experience to live and work in the "school of social life" for a full semester." (Miami University website). Many graduates end up staying or returning to OTR. Based on casual conversation during the course of this study, it appears that many of the students were enrolled in college for social work and were employed as interns or part-time social workers. Based on in depth interviews with residents, advocates, social workers, and activists, to name a few, most of the social workers within OTR had advanced degrees but earned less than their counterparts in other professions.

Tract 11 houses the highest paid individuals with a Bachelor's degree as well as the second-highest paid individuals with graduate or professional degrees. The highestincome earners $(\$ 97,625)$ in tract 16 are high school graduates, surpassing the other cohorts within the tract by a substantial margin. However, tract 16 houses the lowest number of individuals (16.0\%) within the high school graduate cohort. It is interesting to note that the highest-income high school graduates are concentrated in tract 16 , while the majority of high school graduates $(47.6 \%)$ live in tract 9 . Tract 11 has the highest aggregate income $(\$ 254,004)$, followed by tract $16(\$ 218,043)$, tract $9(\$ 156,127)$, tract $10(\$ 155,201)$, and tract $17(\$ 68,042$, though this may be misleading due to missing data), respectively.

Comparing educational attainment (Table 6) and median earnings by educational attainment (Table 7), it is interesting to observe some patterns. The majority of individuals with less than high school graduation live in tract 9 and earn the lowest income in OTR. Tract 9 also houses the majority of high school graduates. The highest- 
income earners in the high school graduate cohort reside in tract 16 but the majority of them live in tract 9. The highest-paid individuals with an Associate's degree reside in tract $10(7.8 \%)$, but are slightly more concentrated in tract $11(9.0 \%)$. While the majority of individuals with Bachelor's degrees reside in tract 10, the highest-income earners within this cohort reside in tract 11 . Oddly, majority of those with graduate or professional degrees reside in tract 16 and make the lowest-income within their cohort.

Table 7. Median Earnings by Educational Attainment

\begin{tabular}{|c|c|c|c|c|c|c|}
\hline CENSUS TRACT & $\begin{array}{l}\text { MEDIAN } \\
\text { EARNINGS } \\
\text { - Less than } \\
\text { high school } \\
\text { graduate }\end{array}$ & $\begin{array}{l}\text { MEDIAN } \\
\text { EARNINGS } \\
\text { - High } \\
\text { school } \\
\text { graduate } \\
\text { (includes } \\
\text { equivalency) }\end{array}$ & $\begin{array}{l}\text { MEDIAN } \\
\text { EARNINGS } \\
\text { - Some } \\
\text { college or } \\
\text { associate's } \\
\text { degree }\end{array}$ & $\begin{array}{l}\text { MEDIAN } \\
\text { EARNINGS } \\
\text { - Bachelor's } \\
\text { degree }\end{array}$ & $\begin{array}{l}\text { MEDIAN } \\
\text { EARNINGS } \\
\text { - Graduate } \\
\text { or } \\
\text { professional } \\
\text { degree }\end{array}$ & TOTAL \\
\hline Census Tract 9 & $\$ 4,583$ & $\$ 8,419$ & $\$ 15,417$ & $\$ 50,208$ & $\$ 77,500$ & $\$ 156,127$ \\
\hline Census Tract 10 & $\$ 14,375$ & $\$ 14,315$ & $\$ 25,339$ & $\$ 38,839$ & $\$ 62,333$ & $\$ 155,201$ \\
\hline Census Tract 11 & $\$ 29,074$ & $\$ 20,625$ & $\$ 13,958$ & $\$ 114,097$ & $\$ 76,250$ & $\$ 254,004$ \\
\hline Census Tract 16 & $\$ 35,417$ & $\$ 97,625$ & $\$ 13,438$ & $\$ 38,750$ & $\$ 32,813$ & $\$ 218,043$ \\
\hline Census Tract 17 & - & $\$ 15,739$ & $\$ 7,875$ & $\$ 4,769$ & $\$ 39,659$ & $\$ 68,042$ \\
\hline \multicolumn{6}{|c|}{ Source: 2008-2012 American Community Survey 5-Year Estimates } & \\
\hline
\end{tabular}

Once a vibrant, bustling neighborhood, today OTR is characterized by poverty, crime and inner-city decay. From 2003 to 2005 , there was a drop of $7 \%$ in property crimes and a drop of $1.1 \%$ in overall crime (Table 7). While crime has reduced, crime statistics for OTR still remain above the average neighborhood statistics (Figure 3). 
Table 8. Crime Statistics in Over-the-Rhine

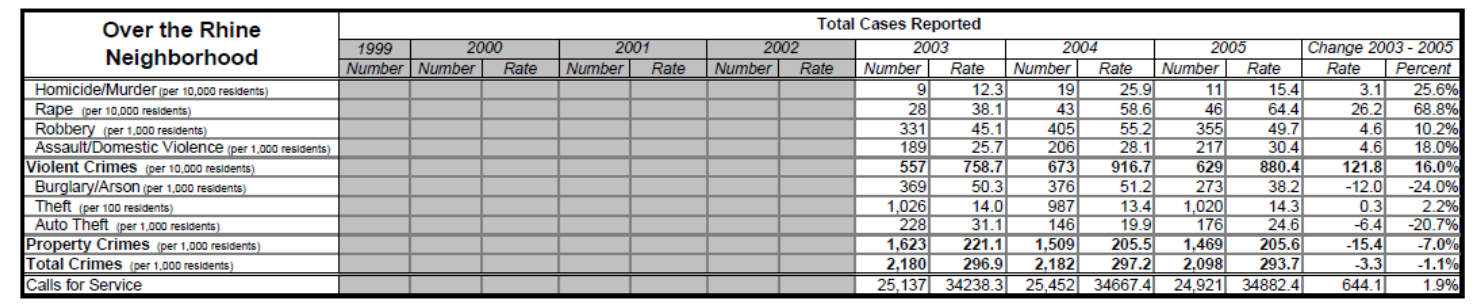

(Source: Cincinnati Police Department,

http://www.hamiltoncountyohio.gov/hcrpc/data_products/pdf/crimeDataMaster.pdf)

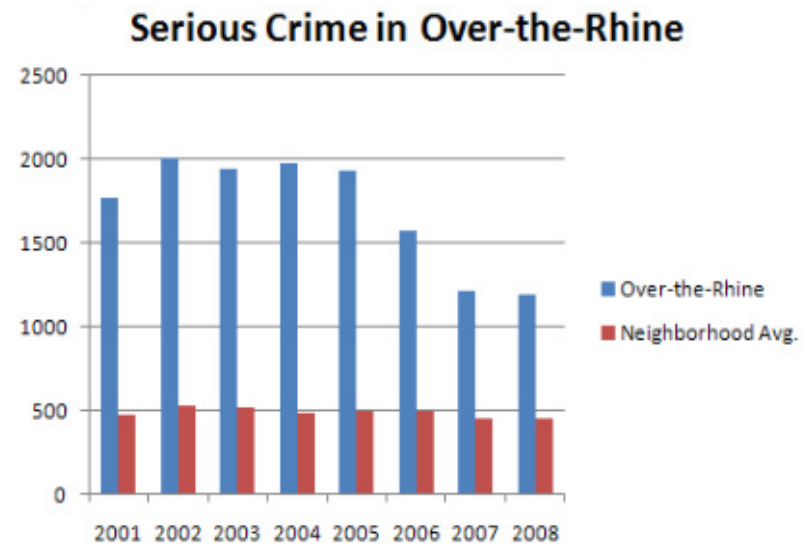

Figure 3. Crime Statistics Comparing OTR to Neighborhood Average (Source: http://en.wikipedia.org/wiki/File:Over-the-Rhine-Part-1-Crime-Per-Year.jpg)

* Neighborhood average represents an average of crime statistics from Cincinnati's 52 neighborhoods.

As city officials and developers rediscover the neighborhood's architectural heritage, OTR has become ripe for gentrification. Today, one can find the physical and social makeup of the community in flux as new middle-class residents replace longtime lower-income residents. The landscape is comprised of new build or renovated middleincome housing next to boarded up, vacant houses. The upgrading of the neighborhood is visible in newly designed street signs and quaint coffee shops next to cash-check-smart shops. Gentrification is a palpable phenomenon, visible not only in the physical motif but also in the social and cultural stratification of the neighborhood. This dissertation aims to 
study the social costs and benefits of the gentrification process underway in OTR since the early 2000s, when the city became more actively involved in the redevelopment process.

\subsection{Research Questions}

\subsubsection{Umbrella questions}

1. What is the rationale for redeveloping Over-the-Rhine?

2. What are the relationship dynamics amongst various actors in the redevelopment efforts?

3. Who has decision making power?

4. What are the perceived social costs and benefits of gentrification?

\subsubsection{Specific questions}

1. City, Chamber of Commerce (economic development) and funding source:

a. What was the rationale and process of gentrification?

b. What is their account of the revitalization of the neighborhood, including economic development and residential change?

c. What kind of support system have the city and the Chamber of Commerce provided during the transitional stages?

d. How do the city and Chamber of Commerce attract developers, new residents, and new businesses? 
2. Developers:

a. What is the rationale and process for developing in OTR?

b. What is the relationship between developers and longtime residents?

3. Community organizations (3CDC, social service organizations, community housing):

a. What is the role of each community organization in the gentrification process?

b. How much support and advocacy is there for affordable housing?

i. Where is the support coming from?

c. What is the general feeling about the revitalization project among longtime residents?

d. How much voice do longtime residents have in the revitalization project?

\section{Residents:}

a. What is the motivation for longtime residents to leave OTR?

b. What is the motivation for newcomers to move to OTR?

c. What is the relationship between new residents and longtime residents?

d. What is the general feeling about the revitalization project among longtime residents?

e. What are the effects of displacement?

f. How much voice do longtime residents have in the revitalization project?

g. How much and what kind of support is available to longtime residents and displaced residents? 
A complete list of interview questions, as approved by the Institutional Review Board, can be found in the Appendix.

\subsection{Methodology}

The qualitative data, gathered via in-depth interviews, participant observation, a focus group, and print media, explored the "intangible" costs and benefits associated with state-led gentrification in OTR. The reason for collecting qualitative data was to develop a comprehensive accounting of the costs and benefits associated with gentrification in OTR, thereby going beyond the "tangibles" and instead exploring a more holistic picture of state-led gentrification.

Using qualitative methods provided for a rich description of the gentrification process, "illuminating the experiences and interpretation of events by actors with widely differing stakes and roles; giving voice to those views are rarely heard" (Sofaer, 1999, p. 1101). Qualitative methods can be informed by quantitative methods and "provide ways to make reliable observations that would not otherwise be possible" (Ibid., p. 1105). Qualitative methods provided for a holistic assessment "which preserves the complexities of human behavior" (Black, 1994, p. 426). Additionally, qualitative methods provided data that captured the nuances and subtleties of costs and benefits to various stakeholders. Such data would not have been available through quantitative analysis alone.

In-depth interviews were used as a means of data collection because interviews enable one to better understand and reify concepts such as the costs of displacement or the loss of social networks (Gillham, 2000). Since the topics are sensitive in nature, face 
to face contact elicited the necessary trust needed to gather thick data. The responsive interviewing model (Rubin and Rubin, 2005) is anchored in interpretive constructionist philosophy with a bit of critical theory.

Constructionists, unlike positivists, believe that different experiences, knowledge, and opinions result in different interpretations of the same events. In other words, there are different lenses through which people view events and experience reality. The critical theory paradigm "emphasizes the importance of discovering and rectifying societal problems" (Ibid., p. 25). In the responsive interviewing model the goal of the research is "to generate depth of understanding, rather than breadth" (Ibid., p. 30). The model emphasizes the fact that both the interviewer and the interviewee are human beings and that they form a relationship during the interview which creates ethical obligations for the interviewer. As such, the design of the research remained flexible through the course of the study. By utilizing the responsive interviewing model, it was possible to gain a deeper understanding of the gentrification process from multiple lenses.

There were a total of 48 interviews conducted along with multiple participant observations at OTR Community Council meetings and tenant meetings; additionally, there was one focus group and print media were used in the form of social media, newspapers, websites, and email exchanges. Of all the interviewees who were contacted, the Chamber of Commerce and a developer who develops market rate and affordable housing specifically chose not to participate in the study. Table 8 and Figure 4 highlight the categories that the interviewees were divided into, the sampling method used, and the number of interviewees in each category. 
Table 9. Breakdown of interviewees

\begin{tabular}{|l|l|l|}
\hline Category & Sampling Method & $\boldsymbol{n}$ \\
\hline Positional perspective & Direct contact & 5 \\
\hline Developers & Systematic Random Sampling & 6 \\
\hline Social Service Organizations & Systematic Random Sampling & 9 \\
\hline Newcomers & Snowball Sampling & 6 \\
\hline Longtime residents & Snowball Sampling & 6 \\
\hline Displaced residents & Snowball Sampling & 6 \\
\hline Key Informants & Snowball Sampling & 10 \\
\hline Total & & $\mathbf{4 8}$ \\
\hline
\end{tabular}




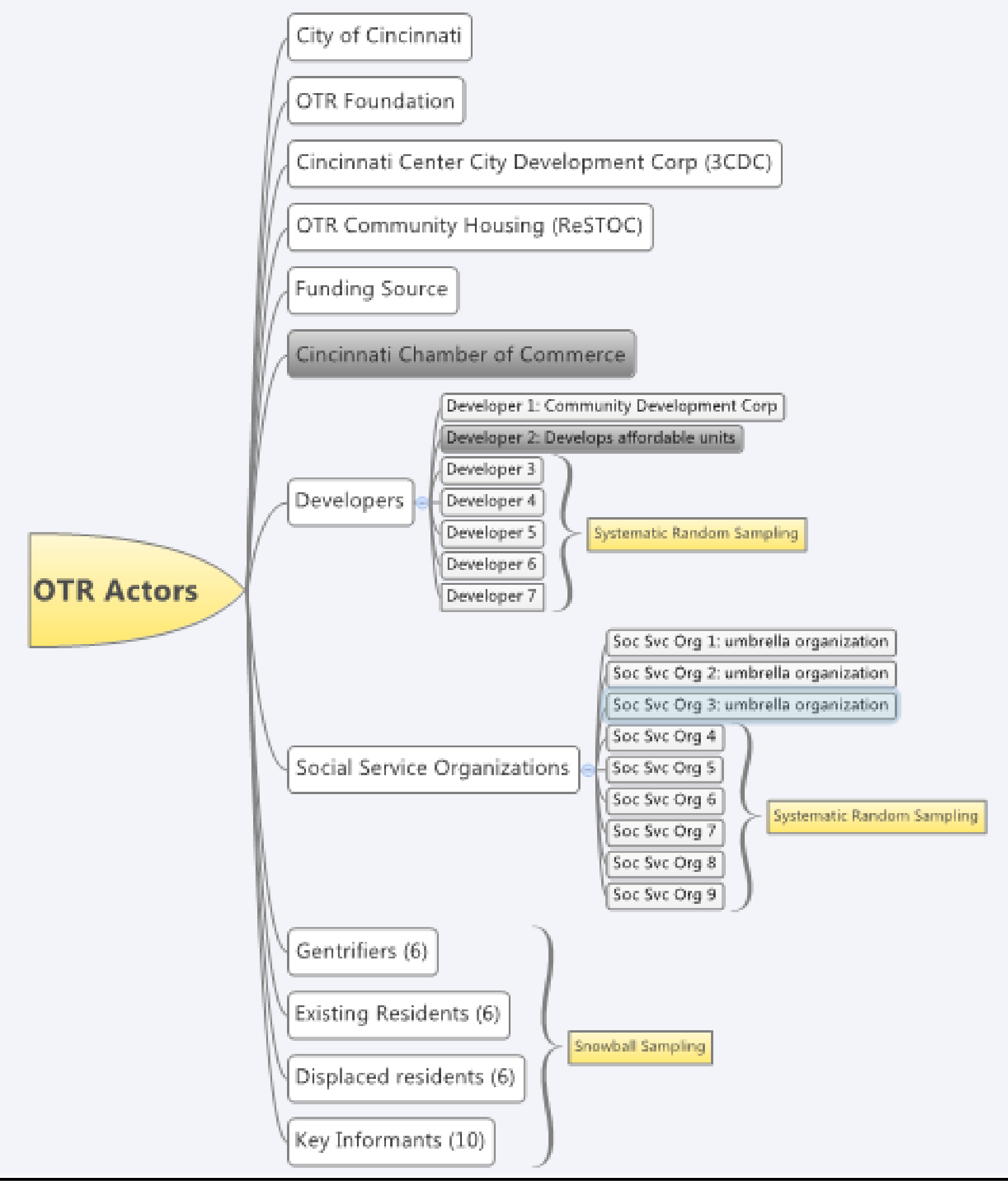

Figure 4. Over-the-Rhine Interviewees 
The interviewees were representatives of the following groups (Figure 4):

- Five interviews were conducted to gain a positional perspective. The interviewees included representatives of the City of Cincinnati, the OTR Foundation, 3CDC, OTR Community Housing, and a funding source. The OTR Chamber of Commerce chose not to participate in the study. Of all the financial agencies providing funding, only one funding source was interviewed due to its unique role in providing financing for affordable housing, making it a key informant (Gillham, 2000). Other traditional sources of funding (for example, banks, private sources, grants) were not interviewed since the cost and benefit information was gathered via interviews with developers, 3CDC, OTR Community Housing, and one of the social service organizations.

- Additionally, of the approximately 17 developers identified from the 3CDC literature, two developers were chosen due to the fact that one of them is a Community Development Corporation that also plays the role of a developer, making it a key informant (Ibid.); the other developer develops affordable housing units in addition to market-rate properties, making it another unique developer. Unfortunately, the second developer chose not to participate in the study. Of the remaining 15 developers, a systematic random sampling procedure was used to create an additional sample population of 5 .

- Of the 18 social service organizations, three umbrella organizations were interviewed due to their extensive involvement in and knowledge of the displaced and homeless population in OTR, making them key informants (Ibid.). Of the 
remaining 15 organizations, systematic random sampling was used to create a sample population of 6 .

- Additional interviews were conducted using a snowball sampling approach to identify gentrifiers, existing residents, and displaced residents. The existing and displaced residents were initially identified through interviews conducted with the social service organizations mentioned above. The gentrifiers were initially identified through interviews conducted with developers; by attending the OTR Community Council meetings; and by visiting new businesses on the main thoroughfare, Vine Street. Interviews were conducted until the point of theoretical saturation (Charmaz, 2010).

- There were also a total of 10 key informants (identified using snowball sampling) who were interviewed to gain a holistic picture of the gentrification process.

\subsubsection{Direct contact}

Certain agencies were identified due to the role they played in the community and their outreach. These agencies included representatives from the city, 3CDC, a funding source, an affordable housing developer, and an agency focusing on the historical designation of buildings in OTR. The agencies were contacted directly, either via phone or email. 


\subsubsection{Snowball Sampling}

Snowball sampling was used to identify interviewees who belonged to the following categories: Longtime residents; Newcomers; Displaced residents; and Key Informants. After conducting an interview, the interviewee was asked for referrals to other interviewees, who once interviewed, provided referrals to other interviewees, creating a "snowball" effect.

\subsubsection{Systematic Random Sampling}

Systematic Random Sampling was used to identify developers and social service organizations. For the social service organizations, there were three umbrella organizations identified because of the scope and nature of their work. There were referrals to two other social service organizations based on reputation and network. These two organizations were removed from the all-inclusive list of social service organizations. The list initially included all organizations in greater Cincinnati, chosen by type of service, attempting to match service to the character and needs of OTR. The list was then alphabetized and narrowed down to two OTR zip codes: 45214 and 45202. After subtracting the organizations that had already been contacted and incidental duplication, the remaining list contained an $n$ of 15 . As per the proposal, every third organization from the list was chosen to equal an $n$ of 6 . In the event that a chosen organization was unresponsive, the next organization on the list was contacted.

For the developers, systematic random sampling was used as well. First, all developers involved in the redevelopment efforts in OTR were identified, yielding an $n$ of 
15. Per the proposal, every third developer was chosen to yield an $n$ of 6 . In the event that a developer was unresponsive, the next developer on the list was contacted.

The data were collected over the course of a little over a year, beginning in the Fall of 2012 and ending in early 2014. Appointments were made in advance and then followed up on, in person, on the agreed upon dates and times. Each digitally-recorded interview took an average of an hour and a half to two hours to complete. The interviews were conducted in an open-ended format in coffee shops, restaurants, offices, and three residences. Interviews in each category were conducted to the point of theoretical saturation. A template for interview questions, approved by the Institutional Review Board, is provided in the Appendix.

In addition to the in-depth interviews, there were multiple sessions of participant observation, primarily by attending OTR Community Council meetings and Columbia Tenant Association meetings, totaling approximately 20 hours. There was one focus group which included members from the community. This interview was digitally recorded as well and data were parsed out during analysis. Additionally, print media was used in the form of newspapers, websites, social media, and email exchanges.

After the data were collected, they were analyzed using a general inductive approach (Thomas, 2006). A general inductive approach "provides an easily used and systematic set of procedures for analyzing qualitative data that can produce reliable and valid findings" (Ibid., p. 237). The strategy has been used in qualitative studies and is guided by specific evaluation objectives (Bryman and Burgess, 1994; Dey, 1993). As 
Strauss and Corbin (1998, p. 12) describe it, "the researcher begins with an area of study and allows the theory to emerge from the data."

For this study, rather than converting the raw audio data into textual form, data were "audio-coded" using the NVivo software program. The software program enabled the coding to be imposed directly onto the audio files, essentially eliminating the need for full manual text-transcription of each interview. First, the interviews were listened to and the content of each interview was spliced into points of categories, deriving a substantive code which was then further delineated. By listening to the interviews in category form, I was able to create theoretical codes. By identifying theoretical linkages and contradictions, I was able to construct the core codes, connecting existing theories and the empirical data collected during the course of the study (Punch, 1998; and Yeung, 1997). The core codes were then queried against each other using NVivio software. For example, the code "displacement" and the code "intimidation and coercion" were queried against each other to create a better understanding of the inter-related nature of the emerging themes. The coded data were then further analyzed, thematically transcribed, and interpreted, thereby establishing clear links between the research objectives and the summary findings derived from the raw data (Thomas, 2006).

\subsection{Demographic Details of Interviewees}

The youngest interviewee was 19 years old, while the oldest was 72 years old. There were a total of 8 African Americans, 39 Caucasians, and 1 other race interviewed. 
There were a total of 31 males and 17 females interviewed. Additional details per category are provided in Table 9 and Figure 5 below.

Table 10. Demographics of Interviewees

\begin{tabular}{|l|l|r|r|r|r|r|}
\hline & $\begin{array}{l}\text { Age } \\
\text { range }\end{array}$ & \multicolumn{1}{l|}{ Black } & \multicolumn{1}{l|}{ White } & \multicolumn{1}{l|}{ Other } & Male & Female \\
\hline Positional perspective & $40-60$ & 0 & 5 & 0 & 3 & 2 \\
\hline Developers & $35-60$ & 1 & 5 & 0 & 5 & 1 \\
\hline Social Service Orgs. & $35-60$ & 1 & 7 & 1 & 6 & 3 \\
\hline Newcomers & $25-50$ & 0 & 6 & 0 & 5 & 1 \\
\hline Longtime Residents & $35-60$ & 1 & 5 & 0 & 2 & 4 \\
\hline Displaced Residents & $19-75$ & 4 & 2 & 0 & 4 & 2 \\
\hline Key Informants & $45-65$ & 1 & 9 & 0 & 6 & 4 \\
\hline Totals & & $\mathbf{8}$ & $\mathbf{3 9}$ & $\mathbf{1}$ & $\mathbf{3 1}$ & $\mathbf{1 7}$ \\
\hline
\end{tabular}

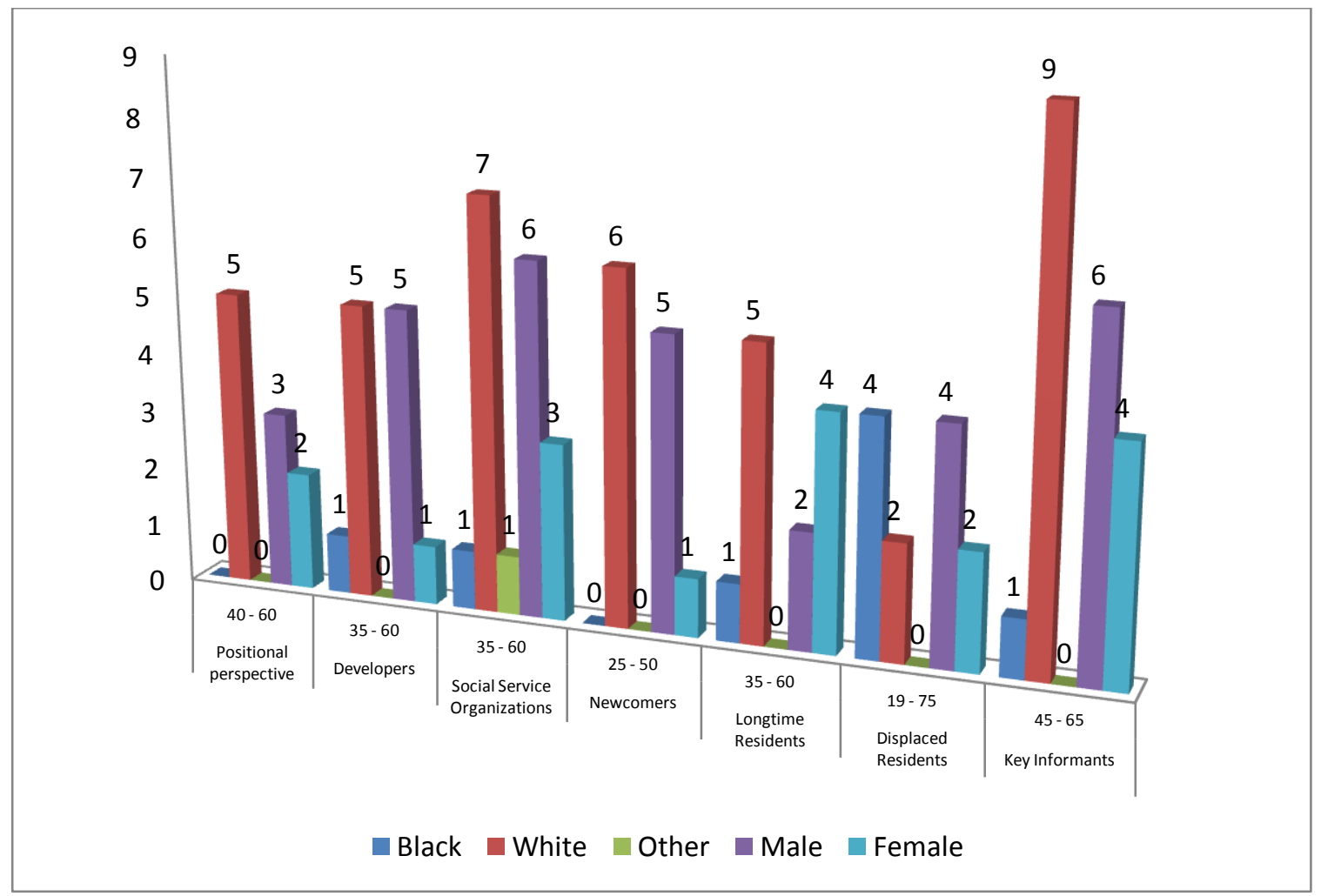

Figure 5. Demographics of Interviewees 
The following chapter discusses the political landscape in OTR, and the impact of redevelopment on various segments of the population: longtime residents; newcomers; and social service organizations. 


\section{CHAPTER 4}

\section{FINDINGS}

OTR, geographically a basin, is a neighborhood that has been described as a gateway for immigrants, a dumping ground for the homeless and mentally ill, and most recently, as a hip and upcoming place. OTR boasts a rich history of migration and social movements, dating back to the 1830's. First inhabited by German immigrants, the neighborhood was transformed into a poor, white, Appalachian neighborhood, which was then replaced by a poor African American population. Today, the city's goal is to make OTR a mixed income, diverse, vibrant neighborhood through deliberate and strategic revitalization efforts.

\subsection{Revitalization and Redevelopment in OTR}

Today, OTR is undergoing rapid redevelopment. When walking down a street, one almost has to walk in a zig-zag manner so as to avoid all the construction road blocks. Run down old buildings are being gutted, preserving and upgrading the Italianate exterior to develop stylish new buildings with commercial spaces, condos, and apartments. Entire streets are lined with yellow construction cranes and construction 
crews. There is a lot of excitement surrounding this construction. As one fairly new-tothe-area business wrote in their social media blog,

"We've sat patiently for more than three years awaiting good news for the empty buildings on either side of us. Our landlord, TF, closed on 1200 and 1208 Main Street this past week, which means we are poised to have new neighbors in the coming year. This is probably the best news we could receive as we reset for a new year. Freshen up your business plans, next generation of Main Street small store owners!" (dated approximately October, 2013).

Although the concept of gentrification can be defined within a couple of sentences, it is a very palpable phenomenon for those living in such a transforming neighborhood. There is excitement and fear as power over turf wars changes hands. In OTR, as in any revitalizing neighborhood, there are mixed feelings about the change that is currently taking place. Proponents describe the change in OTR as positive and progressive, while longtime residents worry about being displaced from their homes.

One can argue that OTR has experienced waves of demographic flux since the area was first occupied by German settlers. This dissertation focuses mainly on the demographic changes that have been taking place since the early 2000 s when the city began to play a more active role in the redevelopment of OTR. Using 3CDC as its development arm, the city has invested significant amounts of money and resources in developing the OTR neighborhood.

The first phase of development was called Gateway Quarters and was bordered by Central Parkway to the south and west, Main Street to the east, and Liberty Street to the north (Figure 6). The second phase of development is currently underway, called Mercer 
Commons. It is a three-stage process (phases II - IV) costing \$63 million, and encompasses 19 buildings and 26 vacant parcels on 2.695 acres yielding 96 market rate apartments, 30 affordable apartments, 28 condominiums, 17,600 square feet of commercial space, and 359 parking spaces. In addition to Mercer Commons, Phase V includes the renovation of another 18 buildings on Race, Elm and Republic Streets yielding 74 condos, 14 apartments, and 8,100 square feet of commercial space for a total project cost of $\$ 23.2$ million (3CDC website). 


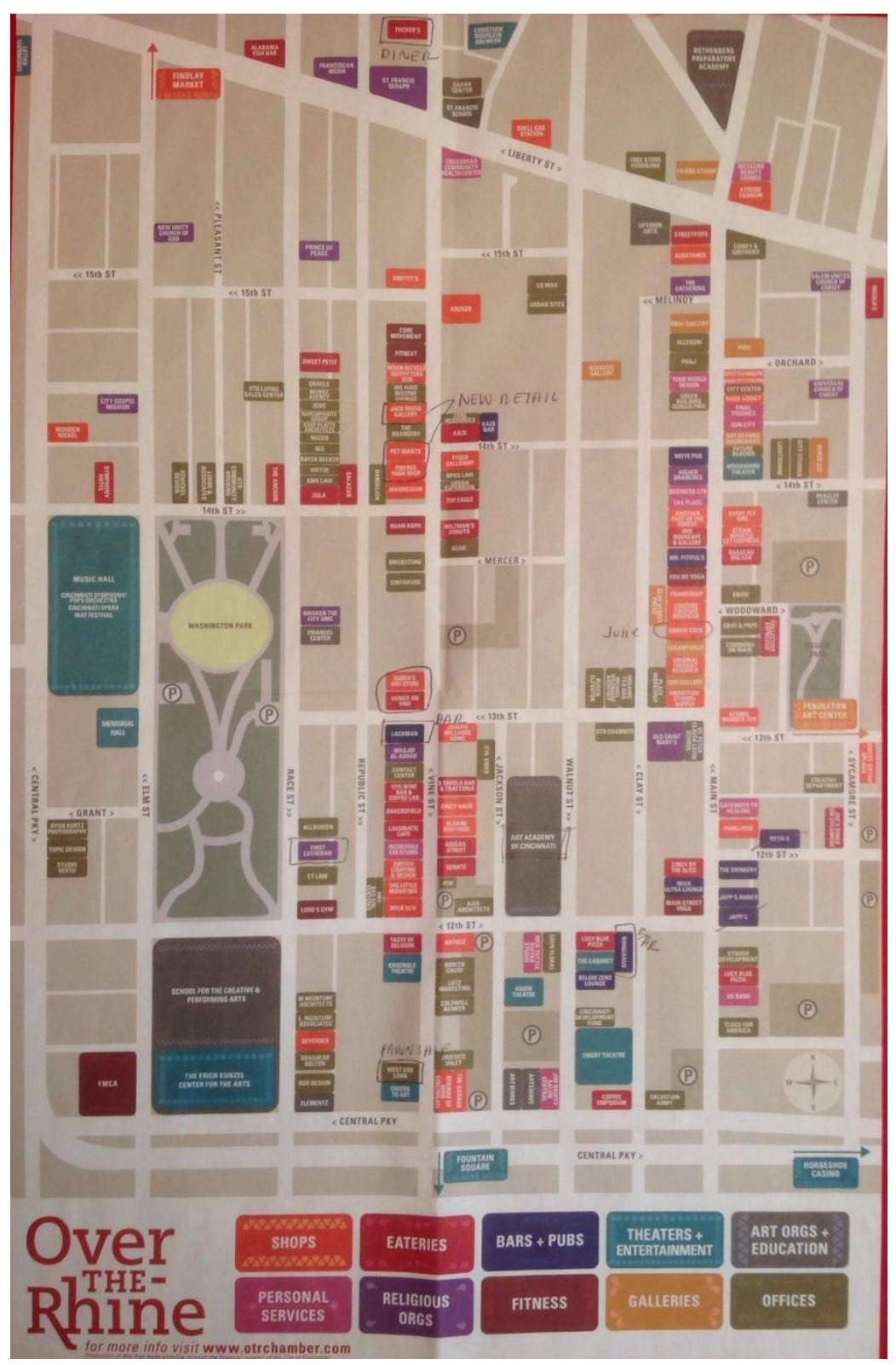

Figure 6. Map of Over-the-Rhine (Source: 3CDC)

As redevelopment has been underway, the prices of buildings have risen sharply.

As a newcomer described to me in an email exchange,

"And along the lines of our conversation - check out this listing for a one bedroom, one bath, one study loft condo in OTR:...Asking price is $\$ 258,000 . .$. I am pretty sure my entire building was less than $\$ 100,000$ 
when the owners bought it 10 years ago! My, how times have

changed." (dated November $8^{\text {th }}, 2013$ )

In order to better understand the dynamics of gentrification in OTR, it is

important to give voice to all the actors in the process. The following section begins by describing the corporate landscape in OTR, with specific emphasis on 3CDC. Next, it describes the role of the city in the redevelopment efforts. The focus then shifts to the second section which describes the various parties who are impacted by the redevelopment, in particular, the longtime residents, the newcomers, and the social service organizations.

\subsection{Political Landscape in OTR}

The governance of a community hinges on the political and economic forces shaping the spatial ethos and thereby its social culture. The OTR community is very polarized, not along partisan lines, but instead along socioeconomic and class lines. While this is visible on the streets, it is most visible in the OTR Community Council meetings, where tensions run high as different issues are addressed. On one side, there are proponents of redevelopment who adhere to a neoliberal imperative. This group includes the city, $3 \mathrm{CDC}$, developers, and corporate interests, determined to redevelop OTR and attract the middle class back to the city. Opponents include longtime residents, social service organizations, advocacy groups, and the homeless population, who see the neoliberal agenda as spurring the gentrification process and weakening their decision making power. To better understand the power dynamics, it is important to understand 
the current political climate of the place, by looking at the roles played by the corporate elite and the city.

\subsubsection{Corporate landscape in OTR}

Development in a neighborhood occurs through the actions of many vested parties. It is analogous to a piece of yarn being woven out of many individual strands of thread. When trying to understand how development occurs in OTR, it is easy to note the cohesion between developers, $3 \mathrm{CDC}$, and other corporate interests. In-depth interviews with various actors provided some insight into the current redevelopment in OTR.

After the 2001 race riots that took place in OTR, the corporate community, primarily located in the adjacent CBD, mobilized to make OTR a better place. As one developer put it,

"The [corporations] knew they had billions of dollars in fixed assets. They can't pick those buildings up and go away. Like, ABC Corporation can't relocate their corporate headquarters. They've got OTR here. For them $\$ 100$ million or whatever it is - to turn that liability into an asset - that's a no brainer."

After much planning, discussion, and organizing, the Cincinnati Center City Community Development Corporation (3CDC) was formed in 2003 as a public-private partnership, with a mission to increase market rate housing and home ownership, and to preserve the historic character of OTR. Unlike traditional CDCs which serve as liaisons between the community and the city, 3CDC serves as the city's economic development arm, playing the role of the main developer. A key informant described 3CDC as a "900- 
pound gorilla" that became a "game changer." With financial backing from the city and the corporate community, 3CDC was able to purchase blocks of buildings, clear building titles, and turn over the buildings to individual developers. By strategically acquiring a critical mass of several different buildings, $3 \mathrm{CDC}$ was able to take development in OTR from scattered, pocket-sized development to one large-scale development endeavor. As one developer described it,

"these buildings were assembled strategically for their location...these guys would then close down the buildings. The buildings were closed and they were fenced in and fenced off. So when renovation of buildings happened, [it] happened in a large scale fashion."

After inception, 3CDC quickly began to purchase vacant lots and buildings, amassing 200 buildings and 170 vacant lots within the city blocks bordered by Central Parkway, Liberty Street, Elm Street, and Main Street (Figure 6). A representative of a social service organization noted that "in the past 5 years, $3 \mathrm{CDC}$ was able to purchase more property than XYZ, an affordable housing developer, could in the past 30 years." 3CDC was very strategic in its acquisitions, purchasing corner lots and buildings, concurrently amassing 50-60 liquor license permits. To date, 3CDC has developed 186 condos, all of which have sold, 70 fully leased apartments with waitlists, as well as 91,000 square feet of commercial space.

While the corporate community and the city enthusiastically support 3CDC, there is a strong anti-3CDC sentiment within the community. Often, $3 \mathrm{CDC}$ is seen as controlling, directing, and managing the gentrification process. As a representative of a social service organization put it, 
"3CDC was created with a purpose. They were created to remove certain people from this neighborhood and move other people in and make a small number of people lots of money. Their board of directors is only major corporations. And so they are doing what they are meant to do."

A displaced resident spoke with great hostility when he described 3CDC as “[Expletive]. Demo-enforcers. They don’t try to help or anything. I look at them like dictators...'I got this money, this power; I can do whatever the [expletive] I want to do."” Others conceded that 3CDC had softened its stance over the past few years and was no longer as severe in its approach. As a representative of another social service organization put it,

"Some part of them is willing to give a little as well. They seem to be more willing to help those that have been here for many years than they were a few years ago. Take for instance the bathrooms. First it was 'no, there's no bathrooms.' Then it was 'well, let's see what we can do."'

A developer provided some insight into the softer side of the "900-pound gorilla" when he said,

"[The sentiment] has definitely softened. To their credit, 3CDC has spent a considerable amount of time and money for what they call their 'homeless to homes project.' The CEO is not bashful about saying, 'our community has done a very, very, very poor job of helping the indigent population, the homeless population, those in need. We have nothing to be proud of'....depends on which side of the alley you sit...some would say 'no you don't wanna see a homeless person on the streets, you wanna move 'em.' [CEO] would argue 'no, I don't want to just move them; I want to help them."'

In the redevelopment efforts in OTR, $3 \mathrm{CDC}$ is often cast as the villain or as the hero. The truth probably lies somewhere in between. As some interviewees observed, 3CDC has done a very good job at doing what it was meant to do - redevelop OTR. Along the way, there have been casualties, such as social service organizations that have 
been moved out of OTR, or longtime residents who have lost their homes. However, almost everyone would agree that, "Cincinnati would not be where it is, and OTR would not be where it is, were it not for 3CDC" (Developer).

\subsubsection{Role of the city in Redevelopment}

While the 2001 riots served as a catalyst, city policy was also changing from a laissez faire approach to a more deliberate involvement with revitalization efforts. The city of Cincinnati, like many other American cities, realized that "for a city to survive as a viable place, politically and economically, we have to counter the white flight and the black flight....the middle class... if we're going to counter blight and have a viable city, we need to improve the tax base. To improve the tax base, we need to have more market rate housing and city policy ought to be directed toward that" (Key Informant). While cities compete against one another to attract corporations or skilled workers to their locales, they also face internal turmoil as there is a hollowing out (Rusk, 1993) of their urban core to the growing, sprawling suburbs. This creates even more tension as the city and the suburbs compete for the same tax revenues. Another key informant put it astutely when she said,

"there [was] no one driving force for renaissance...[3CDC] allowed development to take hold. [I] won't attribute it all to 3CDC because there are a lot of people working [to redevelop OTR]."

When the most recent wave of revitalization in OTR began, two of the biggest accomplishments were to get the public utility companies to bring the neighborhood up to 
code and street calming efforts, such as changing one-way streets to two-way streets, which slowed traffic and increased accessibility to the neighborhood businesses.

A third, very controversial, project that is currently underway is the establishment of a streetcar that would connect different neighborhoods. Proponents believe it will create connectivity and make the city "more progressive" and attractive to new talent. They also believe that the permanence of a streetcar (as opposed to bus lines) shows how dedicated the city is to improving its infrastructure. Opponents believe that spending money on a streetcar when budgets are already tight is not sensible. They also believe that the streetcar will primarily "be a toy for the yuppies" (Longtime Resident), further promoting gentrification.

While $3 \mathrm{CDC}$ spearheads the redevelopment, it works very closely with the city in its planning efforts. As a developer observed, "everything goes through the city." The planning is conducted in a very methodical manner and ranges from infrastructural design such as utility provision to streetscape to parking as well as a financial component where sometimes the city provides a portion of the development costs. As a council member explained,

"We provide seed money but then we also help fund specific parts of the plan. We work side by side on all the issues, from zoning and planning and everything else it takes to redo a building and a plan to redo a building...everything is done in partnership between the city and $3 C D C$, at every level...they are the ones who are developing the plans but it's in partnership. They will then come to the city and say we've gotten these federal dollars, these HUD dollars, these CDBG dollars, and...they needed a million dollars more, so that's where the city comes in." 
Through the establishment of $3 \mathrm{CDC}$, it is clear that the city has rescaled urban governance in OTR through the devolution and privatization of state power, further distancing itself from democratic access and accountability to the local residents. Development plans are often orchestrated "behind closed doors," thereby limiting citizen involvement. Even when resident input is sought, it is often not incorporated into the development schemes. By letting 3CDC spearhead development, the city has created an additional administrative layer between itself and its citizens.

\subsection{Impact of Redevelopment}

\subsubsection{Longtime Residents and Redevelopment}

During in-depth interviews, the longtime residents, social service organizations, and displaced residents had a very different reaction to the redevelopment. While 3CDC, the city, and the corporate community are encouraging the rapid redevelopment of OTR, the longtime residents, social service organizations, and homeless population are not as enthusiastic and are instead more anxious about being pushed out of the neighborhood.

The relationship between longtime residents and $3 \mathrm{CDC}$, the developers, and the corporate community is strained at best. As a longtime resident described it,

"Suspicion that ...people will talk about we're being taken over or [the developers are] not respectful. I know families that have lost housing because of the change."

Many constituents have criticized 3CDC for showing a lack of sensitivity toward the indigent population. As a representative of a social service organization and a longtime resident put it, 
"For the most part, we don't feel like the developers value the folks that are here already...maybe not even thinking negatively about ...but they don't either have a sense of what's already here 'cause they maybe believe too that there's nothing...it's kind of like the whole urban pioneer thing... and the settlers."

"You're an urban pioneer and all the language they use...you know, the way this country was founded...you know, great white pioneers who moved to the West to tame the land that was totally empty or you know had savages on it who didn't need to be there anyway. I mean that language is the language they use to gentrify this community."

When developers were asked about why longtime residents might be opposed to the redevelopment, the answer was simple, uniform, and dismissive of the complex social dynamics at play: "Human nature doesn't like change...change is difficult...people don't like change." Each developer then discussed how the neighborhood had changed for the better, providing the longtime residents with better amenities like increased safety, more beautiful streetscapes, and a vibrancy "that was previously lacking."

It was easy to sense the tension in the room as one longtime resident described the dynamics of neighborhood change in OTR,

[It] felt like tokens...neighborhood people know what's going on, know the concept of gentrification, and that our land is valuable and it's being occupied and taken over by forces that have the power to do it and giving little regard to the little people; little people meaning those with less resources."

Showing sensitivity to the conceptual complexity, a newcomer described the situation as such,

\footnotetext{
"when we moved in here, there's still folks who live on this block and for whatever their circumstances are, don't have a lot of resources and you've got that mix of people coming in. Obviously, you know, we're white and that isn't what the neighborhood has been for a while and there had been
} 
words about whether the renovation is pushing people out of the area or whether it's renovating shells or empty buildings or saving what's left of OTR's character. So, I think the real rub comes when people are moved out of their homes and facilities."

While 3CDC asks for participation from the longtime residents, that input is often ignored, leaving the longtime residents feeling overlooked and voiceless. For example, the redevelopment of Washington Park on $14^{\text {th }}$ Street cost approximately $\$ 48$ million and turned the park from a haven for the homeless to a destination park for the city. The longtime residents fought very hard to keep the basketball courts where young African American males liked to spend time, as well as the deep water swimming pool where children learned to swim. Their wishes were completely ignored and instead the renovated park has a dog park in it. One resident said she felt like their input was nothing more than tokenism. To them, although more beautiful, it no longer feels like their community park.

Another glaring aspect of the redevelopment is that although revitalization is supposed to spur economic growth, the indigent population is not benefiting monetarily from it in any way. For example, when asked whether developers hired locally, most said they couldn't because of a lack of skilled laborers. As a representative from 3CDC explained, "we can’t just put a hard hat on anyone." The city has requirements for minority owned businesses, small businesses, and women owned businesses that the developers are required to follow. Being very candid and speaking in general terms, a developer explained,

"the African American community has frankly done a terrible job of training their workforce. And there just aren't many that will be good. The Hispanics will work...they'll work 12 hours a day and give you 14 hours 
of work in a 12 hour day. And I mean, work hard. That's not true in the African American community. I mean there are certain trades we use that are minority owned that are good guys. They work hard; they do a good job, but they're few and far between. And some of them like to just take advantage of the opportunity. 'well, we know you gotta have certain minorities on the job so you gotta hire us.'...then I gotta hire somebody else to fix your work. We do that. That's what we do. $3 C D C$ will do that...'okay, he's not the low bidder; he's not the best bidder; we're going to hire him and we're going to hire him because we've got to have certain engagement within the community. It's a cost of doing business."

Whether this perception is correct or not or whether it is even a commonly held notion among developers, it is a further hindrance for the local population to become a part of the redevelopment efforts through gainful employment. The community also does not have any training programs available locally so as to develop a local skilled workforce. Neither the city, nor 3CDC has made any effort to implement such a training program.

\subsubsection{Local Voice and Activism}

There has been a very rich history of social activism in OTR. It reached its peak in the1970s - 1980s through a movement called the People's Movement. This movement was headed by an iconic figure by the name of Buddy Gray. During his time, protests were very theatrical in nature, with Buddy and his cohorts being arrested multiple times. One social activist described a multitude of situations where Buddy and other social activists would chain themselves to construction cranes or flood city hall in great numbers. 
Buddy was a staunch advocate for the poor. After inviting the homeless into his home for the night for a number of years, Buddy formally created a shelter called the Drop Inn Center in 1973. A few interviewees recounted how the Drop Inn Center and its inhabitants were moved in the middle of the night to a building next to Music Hall, presumably to make homelessness more visible to those with money. This covert move, described by some as illegal, was spearheaded by Buddy and required the assistance of many social activists who coordinated collective efforts such as driving the shelter's clients in vans in the middle of the night. As a developer recounted,

"Teaching them how to panhandle. Became a magnet, self perpetuating thing. Brought people in, taught them how to be homeless, how to do the homeless thing. And then they kinda put themselves in the face of people with money... you know the old fart, people in their tuxedos, walking up to music hall... [saying] literally, 'well, I better give them some money.'”

Ever since the Drop Inn Center was moved to its prime location next to Music Hall, a prestigious School for the Performing Arts, and Washington Park, there has been much controversy surrounding its location. The city has been trying to relocate the Center for years so as to reclaim the valuable piece of real estate that is currently occupied by the Center. There was a decision made recently to relocate the Drop Inn Center outside OTR, in the neighborhood of Queensgate. Advocates today believe that it will now become very difficult for the Center's client base to access their shelter services due to the lack of proximity. The upside is that its new location presumably has a better architectural foundation and layout and is therefore better suited for its operations.

Buddy died an untimely death on November $15^{\text {th }}, 1996$, when he was shot by a homeless man with schizophrenia who thought Buddy was trying to poison him. There are some within the community who believe Buddy's death was actually an assassination 
facilitated by the opposition. Buddy was very anti-development and through very strategic efforts, had garnered a lot of clout within city hall, thus giving him the opportunity to thwart development. As one developer put it, "wherever development was, Buddy Gray was not."

After Buddy's death, the advocacy group broke into a few off-shoots which are still in existence today. Although there is still a very strong advocacy presence, the power of such groups has waned since Buddy's death. Part of the reason is that Buddy had exceptional community organizing skills. Today, the weakened impact of social movements may have something to do with the fact that it is more difficult to mobilize people around common interests (DeFilippis, 2004; Newman and Lake, 2006; Lees et al., 2008). There are also a very large number of social service organizations that are located in OTR. They are proponents of affordable housing. While there is a very strong sense of activism among a few key players, their challenge lies in organizing the residents. Also, the opposition has grown in power, both monetarily and administratively. As a longtime resident explained,

"But that doesn't mean we've given up. I mean, we're still here trying to stand up for basic human rights and hopefully, you know, we'll be here in the long run. But, I mean, you know...we're up against a lot of big money and power with the corporations of Cincinnati kind of deciding that this is an area they want to...I see it as a takeover, an invasion almost because we really don't have a legitimate voice in decision making."

Based on observing the OTR Community Council over the course of a year, it is clear that there is divisiveness within the community council between the "haves" and the "have-nots." Over the course of the year, there have been an increasing number of newcomers attending the meetings. As an outsider, it was easy to see the power struggle 
and shifting dynamics as the newcomers began to outnumber the longtime residents, further weakening their voice. As a representative of 3CDC, in actuality a public-private corporation, put it,

"so because we're a private non-profit real estate group; we're private; we're a private company and we certainly do... we try to follow that OTR master plan and we listen to the community but...we try to gather as much input as we can... [Q: do residents have a guarantee that their input will be incorporated?] ...nope, we're a private group, so there's no guarantees."

On the flip side, a very remarkable story of successful social justice is the example of a building which used to be called Metropole and is today the $21 \mathrm{C}$ hotel. Some of the 300 plus residents held out on relocation remuneration and 3CDC finally settled the case for $\$ 80,000$. Though small, it was still a great victory for those who were displaced.

Despite past successes during Buddy's tenure and the victory over the Metropole case, the current strength of social activism has weakened. It is strongly present, but latent in a sense. This may be because as properties change hands, the longtime residents are more worried about getting displaced. This base fear seems to create a sense of urgency that is not being translated into a collective identity in the form of tenant uprisings or other community-oriented protests.

Poletta and Jasper (2001, p. 285) describe the term "collective identity" as "an individual's cognitive, moral, and emotional connection with a broader community, category, practice, or institution." While distinct from personal identity, it may form part of a personal identity. Collective identities are expressed in terms of rituals, clothing and so on. 
The theory of a "collective consciousness" was first posited by Durkheim. According to Durkheim (1973), collective representations may range from totemic symbols to moral beliefs (Swindler, 1995). Symbols and rituals serve to "concretize 'collective consciousness,' making the animating power of group life palpable for its members" (Ibid., p. 26). An individual must feel a part of an organized whole in order for collective action to occur. However, a sense of belonging is not enough to spur action.

In the case of OTR, there are numerous murals speaking to the strength of the community. However, while there is a strong presence of social activism, it lacks the cohesion that it had in the 1970s, and especially, the 1980s.

It is important to touch upon a theoretical framework for social movements and resource mobilization. The development of social movement theory can be traced from the collective behavior tradition of the 1950s to the resource mobilization theories of the 1970s to the social constructionism and new social movement theory of the 1980 s (Buechler, 2000). During the 1970s, sociologists (Gurr ,1971; Turner and Killian,1972; Smelser, 1963) viewed social movements as being rooted in shared grievances and alienation, and particularly, in the intensification of such grievances or deprivation. Later scholarship, however, began to doubt the assumption of a close link between preexisting discontent and social movements (Tilly, 1973).

Traditional analysis of social movements and social movement organizations has assumed a close connection between collective grievance and the growth, change, and decline of social movements (McCarthy and Zald, 1977). Resource Mobilization (RM) theory, however, is informed by political sociological and economic theories, more so than the social psychology of collective behavior (Ibid.). According to RM theory, 
"society provides the infrastructure which social movement industries and other industries utilize. The aspects utilized include communication media and expense, levels of affluence, degree of access to institutional centers, preexisting networks, and occupational structure and growth" (Ibid., p. 1217).

If we were to analyze the activism in OTR using the lens of RM theory, the basic infrastructural tenets necessary for resource mobilization are now missing. There are still a few key actors with shared grievances. However, over time, having people displaced has weakened the base or core constituents and potential participants. The displacement of residents has caused instability within the preexisting networks, resulting in administrative constraints. For example, basic communication networks are dismantled as activists are displaced and are no longer "plugged in" to their old networks. There are also lower levels of affluence and access to institutional centers, further undermining the ability for collective activism. The resistance movements are not funded by government or private monies, making even basic communication across members an expensive endeavor. Although social activists attempt to raise money through fundraising efforts, such efforts do not have the sponsorship of donors with deep pockets. For example, ABC Corporation is not likely to donate money to anti-redevelopment groups, as it is not in its best interest to thwart redevelopment.

In summary, as gentrification takes a hold of OTR, key actors are being displaced, changing the "voice" (and therefore, power) of the shrinking group of remaining activists. Displacement of social service organizations is dismantling the necessary institutional pillars, and diminished resources in terms of time and monies present further hindrances for collective activism. 


\subsubsection{The Newcomers and Redevelopment}

Today, when one visits the revitalizing section of OTR, the 2001 riots become a faint shadow of the past. It is a trendy urban district, with a vibrant commercial center and nightlife. When developers were asked how they went about attracting residents, all of them said that they didn't:

"Today, we are the market...pricing at the highest level...now market is full...pretty easy...no fixed up apartments available. Now, there is more demand than housing. We don't really advertise. It's mainly word of mouth. Residents are coming to us."

Developers also attributed part of the demand to changing cultural attitudes. As one developer expounded,

"by this time, Manhattan was cool; and it was played out on shows like 'Friends' or this idea of loft living, like the movie 'Big' and people were like wow, 'I'd love to live in a loft like that.' So it was kind of a consciousness of coming out, like city living could be cool."

One newcomer described how she felt that developers were definitely targeting a certain kind of demographic and ignoring those that did not fall within this subset.

"Yeah, they're for sure targeting a certain demographic. Probably the 2545 range. Probably their next demographic will be retirees - mark my words. Disposable income; upwardly mobile; college educated; white; granite countertops; hardwood floors and they are looking for people to draw away from the suburbs, in my opinion. And I think their hearts are in the right place; I just think they failed on supporting the rest of the neighborhood and that's where I'm like come on guys, step up."

The newcomer was correct in her assumptions, as witnessed in Figure 7. Table 10 provides additional details on the demographics of recent home buyers. It is interesting to note that the majority of new home buyers fall within the $25-30$ age range (33\%), with 
the second largest group falling within 30 - 35 age range (30\%), and the third largest group falling within the $45-60$ age range (15\%). The majority of new home buyers are White (87.4\%), followed by Asians (3.75\%), Blacks (3.31\%), and Europeans (2.35\%), respectively. While there was an upswing in suburbanites moving to OTR in the years 2010 and 2011, the statistics indicate that the new home buyers, on average, came from the suburbs and from within the city in equal parts. Even though half of the new home buyers came from the suburbs, the fact that the other half of the new home buyers came from within the city might undermine the city's claim of increased tax revenues from revitalization in OTR as the inner-city home owners were presumably paying inner-city taxes to begin with.

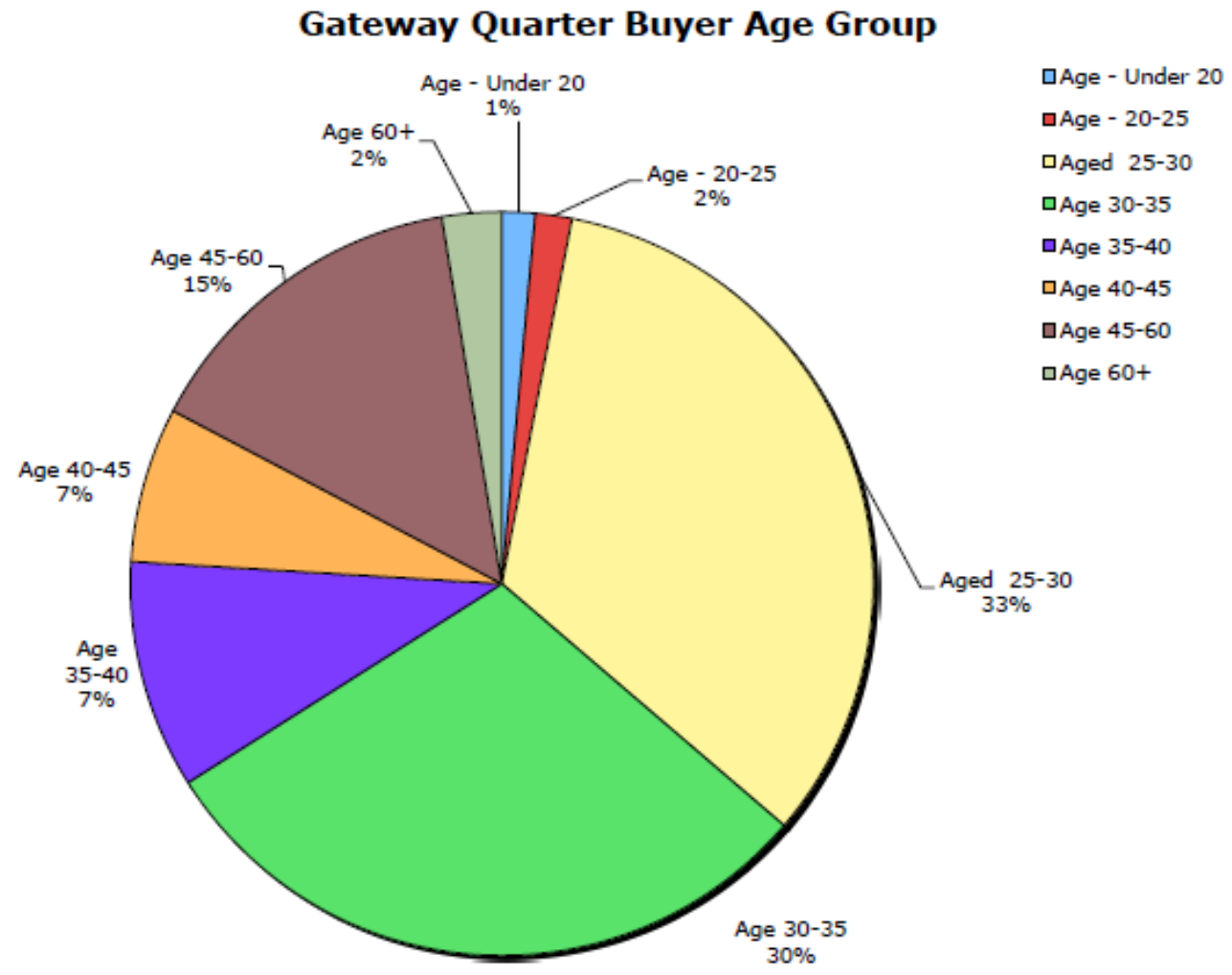

Figure 7. Demographics of Home Buyers (Source: Over-the-Rhine Community Housing) 
Table 11. Overall Demographics of new home buyers (2008 - 2012)

\begin{tabular}{|c|c|c|c|c|c|c|}
\hline & 2008 & 2009 & 2010 & 2011 & 2012 & All years \\
\hline Female & $22.58 \%$ & $32.36 \%$ & $29.41 \%$ & $25.93 \%$ & $31.25 \%$ & $28.31 \%$ \\
\hline Male & $59.68 \%$ & $54.84 \%$ & $58.82 \%$ & $44.44 \%$ & $40.63 \%$ & $51.68 \%$ \\
\hline Couple (Married) & $17.74 \%$ & $12.90 \%$ & $11.76 \%$ & $29.63 \%$ & $28.13 \%$ & $20.03 \%$ \\
\hline Age - Under 20 & $3.85 \%$ & $3.23 \%$ & $0.00 \%$ & $0.00 \%$ & $0.00 \%$ & $1.42 \%$ \\
\hline Age - 20-25 & $1.92 \%$ & $0.00 \%$ & $5.88 \%$ & $0.00 \%$ & $0.00 \%$ & $1.56 \%$ \\
\hline Aged $25-30$ & $26.92 \%$ & $48.39 \%$ & $32.35 \%$ & $14.81 \%$ & $40.63 \%$ & $32.62 \%$ \\
\hline Age $30-35$ & $44.23 \%$ & $25.81 \%$ & $26.47 \%$ & $37.04 \%$ & $12.50 \%$ & $29.21 \%$ \\
\hline Age $35-40$ & $5.77 \%$ & $6.45 \%$ & $11.76 \%$ & $18.52 \%$ & $6.25 \%$ & $9.75 \%$ \\
\hline Age $40-45$ & $7.69 \%$ & $0.00 \%$ & $11.76 \%$ & $7.41 \%$ & $6.25 \%$ & $6.62 \%$ \\
\hline Age $45-60$ & $3.85 \%$ & $12.90 \%$ & $8.82 \%$ & $18.52 \%$ & $28.13 \%$ & $14.44 \%$ \\
\hline Age $60+$ & $5.77 \%$ & $3.23 \%$ & $0.00 \%$ & $3.70 \%$ & $0.00 \%$ & $2.54 \%$ \\
\hline Single & $75.00 \%$ & $83.87 \%$ & $76.47 \%$ & $62.96 \%$ & $65.63 \%$ & $72.79 \%$ \\
\hline Married & $21.15 \%$ & $9.68 \%$ & $14.71 \%$ & $40.74 \%$ & $34.38 \%$ & $24.13 \%$ \\
\hline White & $85.19 \%$ & $93.55 \%$ & $82.35 \%$ & $85.19 \%$ & $90.63 \%$ & $87.38 \%$ \\
\hline Black & $3.70 \%$ & $3.23 \%$ & $5.88 \%$ & $3.70 \%$ & $0.03 \%$ & $3.31 \%$ \\
\hline European & $5.56 \%$ & $3.23 \%$ & $2.94 \%$ & $0.00 \%$ & $0.00 \%$ & $2.35 \%$ \\
\hline Middle Eastern & $0.00 \%$ & $0.00 \%$ & $2.94 \%$ & $3.70 \%$ & $0.00 \%$ & $1.33 \%$ \\
\hline Hispanic & $0.00 \%$ & $0.00 \%$ & $2.94 \%$ & $0.00 \%$ & $0.00 \%$ & $0.59 \%$ \\
\hline Asian & $1.85 \%$ & $3.23 \%$ & $0.00 \%$ & $7.41 \%$ & $6.25 \%$ & $3.75 \%$ \\
\hline Indian & $3.70 \%$ & $0.00 \%$ & $0.00 \%$ & $0.00 \%$ & $0.00 \%$ & $0.74 \%$ \\
\hline First Time Buyer & $71.43 \%$ & $64.52 \%$ & $58.62 \%$ & $48.15 \%$ & $34.38 \%$ & $55.42 \%$ \\
\hline Relo & $28.57 \%$ & $19.35 \%$ & $11.76 \%$ & $18.52 \%$ & $12.50 \%$ & $18.14 \%$ \\
\hline From Cincinnati & $71.43 \%$ & $80.65 \%$ & $71.43 \%$ & $81.48 \%$ & $87.50 \%$ & $78.50 \%$ \\
\hline Moved from Suburbs & & $20.00 \%$ & $75.00 \%$ & $68.00 \%$ & $37.50 \%$ & $50.13 \%$ \\
\hline Moved within Downtown & & $80.77 \%$ & $26.47 \%$ & $32 \%$ & $63 \%$ & $50.44 \%$ \\
\hline
\end{tabular}

Source: Over-the-Rhine Community Housing

Looking at some sales statistics over the course of 2007 - 2012 (Table 11), there were a total of 180 sales and 178 closings, totaling $\$ 33.6$ million. The average sale price over the five years was $\$ 190,126$. It is interesting to note the steady increase in sale prices over the course of the five years, with the average sales price peaking in year 5 (2012) at $\$ 240,495$. However, it is also important to note that the sales prices may have been economically deflated during the years 2008 - 2009, when the housing bubble burst, leading to a financial crisis, especially in the housing market. In spite of the housing 
crisis, home values in OTR continued to rise during the recessionary period (December, 2007 - June, 2009). This may indicate the speculative nature of real estate in OTR. It may also explain the upswing in suburbanites moving to OTR during 2010-2011 in response to declining suburban home prices. Additionally, it is important to note that the sale prices are not always for refurbished dwellings. As three newcomers explained, they purchased dilapidated buildings and then rehabbed the buildings themselves, putting additional money into construction costs.

Table 12. Over-the-Rhine Living Sales and Marketing ReCap (2007 - 2012)

\begin{tabular}{|c|c|c|c|c|c|c|c|c|c|c|c|c|c|c|}
\hline \multicolumn{15}{|c|}{ Yearly Stats } \\
\hline & & 2007 & & 2008 & & 2009 & & 2010 & & 2011 & & 2012 & & TOTAL \\
\hline Number of Sales & & 30 & & 28 & & 31 & & 34 & & 29 & & 28 & & 180 \\
\hline Number of Closings & & 25 & & 32 & & 30 & & 33 & & 23 & & 35 & & 178 \\
\hline Dollar Volume Closed & $\$$ & $4,048,150$ & $\$$ & $5,070,831$ & $\$$ & $5,285,577$ & $\$$ & $6,285,142$ & $\$$ & $4,483,320$ & $\$$ & $8,460,018$ & $\$$ & $33,633,038$ \\
\hline Model Center Visitors & & 181 & & 492 & & 393 & & 179 & & 151 & & 137 & & 1,533 \\
\hline Website Visitors & & 15,624 & & 22,814 & & 24,775 & & 27,198 & & 28,262 & & 31,970 & & 150,643 \\
\hline Coversion Ratio & & 6.03 & & 17.57 & & 12.28 & & 3.89 & & 4.87 & & 4.89 & & 9 \\
\hline Average Sale Price & $\$$ & 155,229 & $\$$ & 160,412 & $\$$ & 176,000 & $\$$ & 186,456 & $\$$ & 222,162 & $\$$ & 240,495 & $\$$ & 190,126 \\
\hline Avg \# of Units Sold Per Month & & 2.50 & & 2.33 & & 2.58 & & 2.83 & & 2.42 & & 2.33 & & 2.50 \\
\hline Percentage of CoOp Sales & & $50 \%$ & & $65 \%$ & & $63 \%$ & & $65 \%$ & & $72 \%$ & & $75 \%$ & & $63 \%$ \\
\hline
\end{tabular}

Source: Over-the-Rhine Community Housing

When asked "why OTR?," most of the newcomers echoed similar sentiments: they really wanted to live in a diverse neighborhood. One newcomer described how the house next to theirs just sold for $\$ 600,000$ and “then down the street there's subsidized housing where people don't know where their next meal is coming from." He further explained what attracted his partner and him to the neighborhood as follows,

"It's because we wanted diversity... and [for our son] .... so that he grows up in a world where he knows that there are people that didn't have the 
same opportunities that he had, that often don't have any control over that whatsoever. They were just born into that situation, just as he was born into a different situation...we didn't come here and pay a million dollars just to be around suburb[an] people."

Newcomers also had a strong disdain for suburban life. They felt that there was "a spirit here" that was lacking in the suburbs. Another newcomer gave examples of more practical reasons such as convenience to work when she said,

"I have wanted to live in the downtown area for a while...I spend a lot of time down here. Being in an urban environment was what I was most interested in. I wanted to be among people who weren't necessarily like me...plus it's an up and coming area...for better or worse, it's become a cooler place to live... Belief in the neighborhood, wanting to be in an urban environment....feeling that culturally that was a better fit for me...paying the price, being down here; convenience to work...all factored in."

\subsubsection{Interactions between longtime residents and newcomers}

Based on in-depth interviews and participant observation, it appears that longtime residents and newcomers coexist in a civil manner. However, with a few exceptions, interaction among the two groups is mostly perfunctory. It is almost as if there are two separate communities that live in one neighborhood. This might stem from the stereotypes that each group has of the other.

Longtime residents are apprehensive about their new neighbors. They have a preconceived notion that the newcomers are there to replace them as residents. They also feel like the newcomers simply don't see them as they walk down the street. They feel invisible, unwanted, and believe that newcomers view them as an inferior group. They 
also feel powerless as OTR is redeveloped and their concerns and desires are not heeded.

As a longtime resident put it,

"[development] does not consider everybody...it just kind of walks over us...not giving us what it is that we need and not really seeing the value that we are to the community. I mean, when I think about the history of our effort here and knowing a lot of neighborhood people here and just their energy and enthusiasm for the community and standing up for their neighbors, I mean there's all kinds of neat things. We're an asset, not a liability."

The vilification of "the gentry" may be somewhat misdirected. Since the redevelopment began, OTR has gained a reputation for being a "hip place" which attracts a lot of young to middle-aged "tourists" from the suburbs. There is a very vibrant night life as the tourists patronize the multitude of bars on Vine Street. Once the bars close, the tourists can be described as being rowdy, and sometimes unruly. One newcomer described witnessing a loud fight between a "yuppy couple" at 2:00AM. A developer described how tourists often litter or may urinate in residential yards. Understandably, the longtime residents feel disrespected and this leads to further alienation as the bars are too expensive for them to patronize. There is a further disconnect between the longtime residents and the newcomers/tourists because most of the bars and restaurants do not employ the longtime residents, nor do they make an effort to do so. There seems to be an overall sentiment amongst new store-owners that the indigent population is an unskilled labor force, incapable of working in the newly-opened establishments.

The newcomers, on the other hand, genuinely do not want to displace anyone. Each newcomer mentioned how much they valued the diversity of OTR. However, the newcomers fail to integrate within the already existing fiber of the community. This may 
be because they do not realize that there is, in fact, a community already in place. Also, the more affluent newcomers and the low-income longtime residents have little occasion to mingle or even communicate with one another in social settings, causing further alienation between the two groups.

When newcomers purchase refurbished homes in OTR, they are deeply committed to the neighborhood. As homeowners, they have a vested interest in the health of the neighborhood. Misguidedly, the low homeownership rates in OTR suggest to some newcomers that there is no emotional attachment to the neighborhood on the part of the longtime residents. As one newcomer described the neighborhood,

"very few of the places here are owner occupied by the people that have been here a long time. They're a very mobile group...so the people that live here do not have an investment in this area other than it's a place to live and there are a lot of other places to live, too."

If we were to analyze the statistics on mobility as presented in Table 12, of the 4.511 individuals for whom residence status a year ago was calculated, majority of the population (3,318 individuals, or 73.6\%) lived in the same house, undermining the newcomer's claim of mobility among the longtime residents. 
Table 13. Residency Status 1 year Ago

\begin{tabular}{|c|c|c|c|c|c|}
\hline CENSUS TRACT & $\begin{array}{l}\text { Residence } 1 \\
\text { year ago- } \\
\text { Same house }\end{array}$ & $\begin{array}{l}\text { Residence } 1 \\
\text { year ago- } \\
\text { Different } \\
\text { house in the } \\
\text { U.S. - Same } \\
\text { county }\end{array}$ & $\begin{array}{l}\text { Residence } 1 \\
\text { year ago- } \\
\text { Different } \\
\text { house in the } \\
\text { U.S. - } \\
\text { Different } \\
\text { county }\end{array}$ & $\begin{array}{l}\text { Residence } 1 \\
\text { year ago- } \\
\text { Different } \\
\text { house in the } \\
\text { U.S. - } \\
\text { Different } \\
\text { county - } \\
\text { Same state }\end{array}$ & $\begin{array}{l}\text { Residence } 1 \\
\text { year ago- } \\
\text { Different } \\
\text { house in the } \\
\text { U.S. - } \\
\text { Different } \\
\text { county - } \\
\text { Different } \\
\text { state }\end{array}$ \\
\hline Census Tract 9 & 487 & 274 & 90 & 52 & 38 \\
\hline Census Tract 10 & 667 & 276 & 50 & 16 & 34 \\
\hline Census Tract 11 & 689 & 65 & 63 & 38 & 25 \\
\hline Census Tract 16 & 854 & 21 & 9 & 3 & 6 \\
\hline Census Tract 17 & 621 & 45 & 44 & 34 & 10 \\
\hline Total & 3318 & 681 & 256 & 143 & 113 \\
\hline \multicolumn{3}{|c|}{ Source: 2012 ACS 5 year estimates } & & & \\
\hline
\end{tabular}

Just as the longtime residents, newcomers also have preconceived notions. Most of the newcomers that were interviewed see longtime residents as a lower socioeconomic group that has been disenfranchised for generations and needs to be helped. Some newcomers talked about how they made it a point to say hello to the indigent population - the panhandlers. Others mentioned how they recognized familiar faces and would sometimes purchase a local newspaper called StreetVibes from them. There is a sense of patronization in their interactions.

The form in which development occurs does not help the cause in any way and may in fact exacerbate cultural alienation. As a representative of an affordable housing developer described,

"There's a development called Parvis. It's on Vine Street and there's an alley behind it called Parvis Alley...then our property is right on the other side and backs up to Parvis Alley too...so our building front on Republic, 
backs into Parvis; their property fronts on Vine Street and backs into Parvis. When they developed it, they did a really neat design in the back of their building for exclusive use of Parvis Alley by their residents, putting gates up, locked gates; getting the city to privatize those alleys for their use... and so in that, literally walling our folks off...which, you know, is unfortunate...so then the folks moving in just automatically, without thinking, assume that this is all ours. This alley's ours; this is our space.

And I think when people move in, they aren't encouraged, it's kind of like 'I'm moving in in spite of the low income folks here'...not everyone for sure...but that there is an opportunity to build relationships or that there's somebody here already. 'Cause I think sometimes the way the neighborhood's portrayed, people might think like it's largely vacant and there's nothing here of value; they don't realize that there's already folks living here who have a history, who have a stake in the neighborhood"

\subsubsection{Social Service Organizations and Redevelopment}

Many interviewees believed that there were too many social service organizations located in OTR. It is a chicken and egg syndrome. There is a concentration of poverty in OTR, and maybe that's why there is a concentration of social service organizations - to serve the needs of the people in the community. Or maybe there is a concentration of too many social service organizations, thereby attracting the low-income and homeless population to the area.

When asked if there were too many social service organizations in OTR, dating his explanation to the 1980 s, one developer mentioned that,

"I think we counted with the chamber something like 115 social service organizations. Like, you could get a sandwich or you could get a free meal at one of 12 different places at any given time...so, what neighborhood can support that?...I mean how could that be good on any level. It was kind of like, 'let's create a mall of poverty - it was insane'." 
A newcomer also mentioned that there were too many social service organizations in OTR, when he said,

"I think there are a lot of shelters here because it was cheap to buy the buildings here; people they were serving didn't mind coming into this neighborhood. Now that's changing. They're realizing that we just have too many out here."

Another developer described the social service organizations as "fiefdoms" that were interested in protecting their "empires." He mentioned how there were directors and employees, all getting paid to do the social service work and that they had self-serving needs such as employment and/or their current clout. He also felt like the current system simply "warehoused" people rather than catering to individualized needs and that there needed to be a centralized agency to streamline the process. While there is currently a centralized system for the greater Cincinnati area, there is not a unique centralized system for OTR.

There is an effort being made to relocate social service organizations to other neighborhoods - regardless of where their client base is being relocated. Social service organizations recounted stories of how some of them had been moved out of the neighborhood, making it difficult for their clients to use their services due to transportation logistics. Many wondered how much longer they would be in OTR.

They also discussed how the different agencies did, in fact, coordinate their outreach programs. For example, XYZ organization served meals from 12:00 - 2:00, while $\mathrm{ABC}$ organization served sandwiches from 2:00 - 4:00, thereby staggering the service provision. While there may be some duplication of services, the organizations have a close-knit network whereby the social service provision is as complementary as 
possible. However, one of the representatives of a social service organization mentioned how there is some form of a "prisoner's dilemma" situation because the agencies are applying for the same funding grants, which creates an incentive to withhold information from one another. While that may be true on the administrative level, all the organizations are on shoe-string budgets, necessitating streamlined operations.

Based on in-depth interviews, it seems that the goal is to consolidate, reorganize, and relocate the social service organizations. As a city official described the plans,

"Completely reorganize how we deliver services for the homeless, which hopefully, will be better than what we have done historically. But, part of that is getting away from one shelter to having multiple shelters that service different needs. Folks with mental health issues versus folks with substance issues...families...rather than just having everyone put together. That's not really beneficial. That's a really tough area. Broadly speaking, that's the idea...I think that causes a lot of angst."

By relocating or displacing the current network of social services that are available, there is an immediate strain on the remaining service providers as they struggle to cater to the needs of their expanded client base with diminished support from the provider network. It is also problematic that the relocation of social service organizations is not done in tandem with the relocation of their client base, thereby putting added pressure on both the displaced agency and the displaced client base.

Having analyzed the impact of redevelopment on various segments of OTR, the next chapter focuses on an analysis of gentrification in OTR. More specifically, it discusses the social benefits and social costs of revitalization; displacement and retention; the displaced and homeless; and an analysis of the often interchangeable words 'revitalization' and 'gentrification.' 


\section{CHAPTER 5}

\section{ANALYSIS OF GENTRIFICATION IN OTR}

\subsection{Social Benefits}

Besides obvious financial gains such as tax revenue increases from property taxes, sales taxes, income taxes, and business taxes, and additional income to the city via license/permit fees and parking, to name a few, there are many intangible benefits to redevelopment. Interviewees mentioned safety as one of the biggest benefits as redevelopment reduced or displaced the criminal element out of OTR.

Others referred to the benefits of creating a more diverse community. As a developer mentioned,

"I would say that a neighborhood...I forget at what we figured... if it was something like 20 percent below poverty line residents, you know, that was kind of the tipping point... if you get that mix wrong, then like what happens is that the culture of the kids is a poverty culture instead of a culture of aspiration."

\subsubsection{Creating a culture of aspiration}

The emancipatory city thesis, which describes gentrification as a unifying process creating cultural diversity, tolerance, liberation, and social interaction, has been presented 
in the works of Ley $(1980,1994,1996)$, Butler (1997), and Caulfield (1989, 1994). Social mixing allows people of different socioeconomic backgrounds to interact with one another, "broadening horizons and raising expectations" (Lees et al., 2008, p. 199). A representative of an agency echoed this position,

"Creating this diversification I think is a benefit...I think that if I am around people that are different than myself, unless I'm an idiot, I should learn something from them; from that exposure, from that engagement, from that observation of people with their troubles...I had to walk to a meeting this morning and I saw a couple of guys in different buildings, sitting on the stoops with a shopping bag of everything they own, bundled up, and I'm thinking 'jeeze, these poor guys, this [cold] weather is just killing them'...nothing I can do about it but I'm confronted by these gentlemen who have nowhere to go and it's societal. I think it's okay that I was exposed to that. I think it makes me understand society a little better."

What the interviewee was describing was a "trickle-up" effect, as the learning was done by him, an upper-middle class resident, instead of the learning being parlayed to a low-income person. This trickle-up effect is interesting because it has not been mentioned previously in the existing scholarship on gentrification. Byrne (2003) discusses the positive "trickle-down" effects of gentrification. A key informant described how when the indigent population is displaced, they form new networks with more well-to-do families, creating the chance for upward mobility. Another interviewee echoed Byrne's sentiment when he said,

"I think the redevelopment efforts should reduce the cost of the social service system. It has to have a reverse effect on some people....there have to be some people who see knuckleheads like me and you know go 'maybe I can do a little bit better; maybe I can pull myself up'...because they see it; they aren't just surrounded everyday by homeless people. They also observe successful people. It has to have some kind of a trickle-down effect, I think." 
It is important to note that "upward mobility" does not simply happen by observing a person in a suit. The indirect realization of the possibility for a better life, or direct aspirations for a better life, are not enough to overcome poverty. There is a need for job training programs that can enable a person to develop a skill-set that is marketable. Such a government-sponsored program has never been in place in OTR and there seem to be no plans to create such a program by the city or by $3 \mathrm{CDC}$.

Although Blomley (2004) argues that interaction in mixed neighborhoods is limited and can lead to social segregation and isolation, this is not always the case. One newcomer recounted a story of how he helped connect a low-income resident to the wealthy elite of Cincinnati, resulting in an upper-middle income resident offering to pay for the low-income resident to go to college. While this may be a drop in the bucket, there is social mingling that is occurring in certain pockets. As a displacee described her reaction to the redevelopment,

"A lot of people have misconception [s] and I was one of them. I had misconception on corporate America. And half of these people down here, these are corporate America people. I had a misconception because I finally found some that care. Everybody is not evil, like everybody is trying to paint it out to be. And I feel like I don't care what kind of class you are, 'cause a poor man can be as selfish as a person with money...you can't put it on a person with money. It's just a person, period. Yeah, I had real misconceptions about a lot of people and a lot of things and I had to learn...everybody's not the same and some of it is stuff, it's good what they are doing, but a lot of it is out of selfish gain... and that piece of it is not good but like Washington park...everybody had a gripe about it but it's a good thing." 


\subsubsection{Washington Park}

Many interviewees described Washington Park (previously mentioned in Section 4.3.1.) as a tangible example of a social benefit. Proponents described how it was so endearing to see the diversity in the park, with children of all socioeconomic and ethnic groups playing together while the adults all interacted with one another. However, opponents of the redevelopment mentioned how some of the homeless population had been displaced and there were fewer amenities present (for example, there are no longer any basketball courts in the renovated park). One homeless interviewee described the contentious situation:

“But everybody's making a big gripe, 'oh $\$ 48$ million;' so what ....look at these kids. And that's what it's about, you know, it's about everybody coming together, and nobody's looking at that aspect. They're looking at 'oh, this was our park; this was our stuff and they're taking it away.' No... and I felt that was unfair to the people who re[did] the park because you're looking at gimme, gimme, gimme....but you're not trying to give; just take, take, take; it's not good. Not good at all."

The park also has music nights and different activities that encourage social mixing.

\subsubsection{Other Social Benefits}

In addition to the overall beautification of OTR, in the form of the park and the streetscape, the city and $3 \mathrm{CDC}$ also required the public utility companies to bring the utilities up to code.

Some of the newcomers also mentioned how the proximity to work enabled them to walk, creating a new "car-averse," urban, "green" culture. Others mentioned the 
increased vibrancy (due to increased safety) as a social benefit of redevelopment. Some also mentioned an increased sense of civic pride and increased homeownership rates, making them feel like they are living "in a real city" (Newcomer).

While newcomers and corporate interests were excited about OTR serving as a prototype for "a melting pot" (Developer), longtime residents and social service organizations were not as enthusiastic and had a difficult time answering the question. A representative of a social service organization mentioned that financial benefits were directed toward the corporate community alone and that it was difficult for him to see any social benefits from gentrification, other than "maybe the trash gets picked up more frequently." As a longtime resident tried to articulate her answer, she said,

"Yeah, so, does it look prettier; does it look fixed up? Ohhh...the neighborhood is really looking great, but to me, the people make up a community and I miss people that are no longer here...so I would say there are improvements, but who's benefiting?"

A Key Informant echoed the sentiment when he said,

"for the residents, there are not that many benefits because they're not owning the businesses; they're not working in the businesses. The benefits haven't been that great for the people who live here, that were here before the gentry. For the gentry, it's economic opportunity from which to build their wealth and start their lives. For the city, it's a shining new community...once degragated[sic] place that's now been turned around. So I'm not sure; you're going to have to ask somebody else about the benefits." 


\subsection{Social Costs}

The majority of scholarly research points to displacement as the greatest cost of gentrification (LeGates and Hartman, 1981, 1986; Lyons, 1996; Newman and Wyly, 2006). The dynamics of displacement are further discussed in the next section. As displacement occurs, there are tangible repercussions. The greatest ripple effect is the erosion of social capital. As longtime residents are displaced, their social networks are broken, leading to increased costs such as the cost of daycare, instead of a neighbor watching the children while the parents work. Once the neighbor is displaced, that support system is lost. As a longtime resident explained,

Even if you're in a situation where you might not always have a lot of money, you at least have that support base still to where you can at least work together to make it through the end of the month. Or, you know, till somebody gets off work, if you need to pick somebody's kids up from daycare or something like that for them. All these things, they're an intricate network that don't always require money. But they do require people to be able to work together, to live together, to know each other. And even if you weren't actually related to your neighbor, you might get so close that they do become family and you start calling them your cousin or you aunt...that's the kind of network we had at one point, very strong in OTR but we no longer have as much of it. It's still there but it's not like it used to be [because of the displacement of people]."

The displacement, coupled with the stress of moving, loss of home, loss of social networks, and loss of community, all create psychological costs. As friends and neighbors are forced to leave the neighborhood, the social fabric of the community becomes eroded, often creating resentment and hostility toward the newcomers, further intensifying cultural alienation. 
As displacees move to adjacent neighborhoods, there is alienation amongst neighborhoods. As a city representative explained, neighborhoods that are not receiving redevelopment funds feel resentful and alienated. Also, as the displacees move in, they create a strain on existing services within the new neighborhood. There are also turf wars and an increase in crime which causes further instability. These are all tangible societal costs.

The displacement of residents and social service organizations also requires a rearrangement of how services are delivered to clients, putting an added strain on the organizations that are still located in OTR. Some displacees may try to come back to OTR to access those services that are not available in their new neighborhoods. As a Key Informant explained,

"Gilding the ghetto is maintaining the ghetto; dispersing the ghetto is the idea of giving people the opportunity somewhere else; where there's less crime, better schools, all that. So, the positive effect of gentrification on the existing neighborhood is that the people might end up better off. They don't always immediately end up better off because if they move to places; if you force them to move and you don't provide support services, they are not necessarily immediately better off in the new environment...on the lowest end of the perspective, you've created social instability by breaking up existing social networks. And those social networks include those social services that are there. You may be putting people in neighborhoods where there aren't those social services they need, available. People would try to come back and get those services, I would think."

Many interviewees mentioned how the problems of poverty, crime, and other pathologies are simply being pushed out to other neighborhoods, "out of sight" (Newcomer). Another newcomer mentioned how "the focus is on building, rather than 
fixing." Some also noted how those displaced may not be getting the same supportive services that they had in OTR.

As the demographic makeup changes, the culture of the place changes. Resistance movements become weaker as the voice of the neighborhood (Chernoff, 1980) changes due to displacement of local community activists, which leads to further polarization of the community. A developer described how as OTR becomes upgraded, it has lost some of its "grit." He mentioned how without that urban grit, it is no longer the same neighborhood. Another impact of redevelopment is the onslaught of suburban tourists to the neighborhood. The tourists can often be belligerent and disrespectful or even oblivious to the local culture. This creates further hostility between the longtime residents and the newcomers because longtime residents tend to "lump together" the newcomers and the tourists.

There are also other quantifiable costs such as increased costs of municipal services, law enforcement, developer subsidies, infrastructural outlays, costs associated with the move, and sometimes, increased costs of homelessness. As previously mentioned, homelessness has associated costs related to mental health, physical health, encounters with law enforcement, substance abuse and housing. A 2006 study by the Partnership to End Long Term Homelessness finds that the 150,000 chronically homeless people in the United States cost $\$ 10.95$ billion per year in public funds. When coupled with developer subsidies, infrastructural outlays, costs associated with increased police enforcement, and stabilization of adjacent neighborhoods, the monetary costs may in fact exceed the monetary benefits such as increased tax revenues. 
When asked about social costs, just as it was difficult for opponents of redevelopment to talk about social benefits, proponents of redevelopment answered by discussing the positives of revitalization or answered by saying, "I don't see any negative costs" (Key Informant).

Since the 2000s, there have been new policies adopted that impose further social costs. At the federal level, the restructuring of Section 8 subsidized housing vouchers in 2000, whereby the Section 8 voucher now moved with the person rather than being attached to the rental unit, resulted in an out-migration of low-income residents from OTR. This led to a weakening of the advocacy groups that used to exist in OTR, further diminishing their decision-making power.

After the 2001 riots, the city of Cincinnati adopted the "Impaction Ordinance" in October of the same year. The Impaction Ordinance identified the concentration of subsidized housing in certain "impacted" neighborhoods as the core of the problem and proposed to deal with it by "forbid[ding] the City of Cincinnati from spending, approving or in any way condoning more subsidized low-income development in those areas deem[ed] impacted." The ordinance also directed the city to "identify the neighborhoods that are impacted by an over-saturation of low-income residents," and to "require that Community Development Block Grant (CDBG) monies that are designated for new lowincome development not be spent inside the City of Cincinnati until there is more equitable regional affordable housing" (Diskin and Dutton, 2002). The rhetoric used was that de-concentration of poverty was the solution to the city's problem. However, by restricting affordable unit supply, the city further lowered the availability of affordable housing for the low-income population. 
At a neighborhood level, the designation of OTR as the Historic District in 1983 and as the most Endangered Historic Place in 2006 resulted in stricter fines for building violations that further impacted the low-income residents, causing displacement, as the fines were too costly for them to afford. While landlords were ultimately responsible for the fines, the costs were often passed on to the tenants in the form of increased rents, putting further economic pressure on tenants already living on shoestring-budgets. The designations also had an unintended consequence of promoting slum-lording as the longtime resident homeowners now had an incentive to let their properties fall into disrepair due to the onset of gentrification. As the buildings' conditions worsened, the buildings became ripe for purchase by a developer or 3CDC. The next section discusses displacement, as it is occurring today.

\subsection{Displacement and Retention}

Displacement, within the context of gentrification, occurs when the lower-income indigent population is pushed out of the neighborhood due to various factors such as an increase in property values and rents, and is gradually replaced by a middle to uppermiddle income demographic. Although 3CDC and a few other constituents maintain that there has been no displacement, majority of the interviewees said that displacement had, in fact, occurred but that it was at a nominal scale and that the relocation was handled with respect and dignity. Although unable to track it, the corporate interviewees also asserted that those displaced were better off in the long run. Unfortunately, in traditional 
gentrification studies, it is very difficult to track displacees - either numerically or geographically.

When asked about displacement in OTR, consensus amongst developers was that there was displacement, however "those that were displaced, needed to be displaced" because they represented the criminal element in OTR. All developers also insisted that the buildings that they purchased to redevelop were vacant, run-down buildings. As one developer said,

"I believe the objective is not to run people out, it's to develop buildings that were basically vacant. It's not like they're coming in, buying rundown residential units, kicking all the people out and then developing some high rise that only the uber, uber rich could afford."

3CDC's response to the question of whether there had been displacement during the revitalization was that "with the exception of this building, every building we have purchased has been vacant...so we haven't displaced anybody. Like I said, with the exception of this building... it wasn't a place that these people wanted to live... so we actually helped pay for the relocation of the handful of residents in this building."

Speaking about the same building, a representative of an affordable housing developer described how "if you came down the street today, you'd have no idea that for 40 years that building was alive with low-income families. There was a school across the street, and we had a market around the corner; a deli that served sandwiches...now you would never know that."

Another developer provided a more nuanced understanding of the ripple effects of revitalization: 
"[the redevelopment] has created a problem by moving folks who couldn't afford to stay out into other communities, therefore putting pressure on those communities. It has moved, I believe, some criminal element out of OTR and to the West side of Cincinnati up to Clifton, complicating life up at University of Cincinnati, out into Westwood and Mt. Airy, and Corryville township. So that has been probably an unintended negative, unanticipated consequence...there is not intentional displacement of folks that want to live here.

The city echoed this sentiment and a representative described displacement as one of the intangible costs of the redevelopment when he said,

"Yes, there's definitely been buildings that people have lived in that have been bought and turned into higher end condos and apartments. There is an attempt every time that happens to find housing for those people. Sometimes that housing is not in OTR.

Yes. There has been a shift to the West side; we're seeing a crime increase, and so, yes, there are specific examples where people have been displaced because of the redevelopment. It is not perfect and nothing ever will, but there is a real attempt to not gentrify OTR, and to make sure that any person that is displaced finds housing that they can afford... and that wherever it is, the amenities they need are also there."

When speaking to longtime residents, the underlying sentiment was a palpable fear of displacement and, for some, resentment that the redevelopment was not to benefit the longtime residents and instead geared toward the newcomers. Longtime residents and social service organizations recounted countless stories of displacement - of both residents and service providers (such as mom-and-pop stores and social service agencies). Some longtime residents talked about how stringent landlords had become with rents and utility bills, evicting residents over the slightest infraction.

"If you live where I live... and walk the street...everywhere you look, everything is high end... and looking outside...I'm not going to be able to afford that. You just see the building and, you know, where are we gonna be...in ten, fifteen years when they get all of this situated? Where are the 
low income people gonna be? I mean you got some, out here, in those apartments...they stay while they can but otherwise they're not because they missed one calculation... moving all of us out. We've got families, children, they could be in school...they're just moving all of us out...families being uprooted 'cause they're taking everything from us."

"Out of sight, out of mind. Just go somewhere, we don't want you."

"After we moved out of there [20 years], they let a company move in there...after we moved out, the new company moved in, they increased the rent $20 \%$. They fancied up the building and everything. I told my wife 'we should call up the director and ask him why they didn't fancy up the building when we lived there?'”

Interviewees also mentioned how the displacement seemed to happen overnight.

As one newcomer observed,

"I noticed the other day...there's a building at the corner of Clay and $12^{\text {th }} . .$. you can't walk by without getting a contact high ... and then I walked by the other day and I noticed a big dumpster outside and it had all new windows and no one was living there... and all I can think is those people were probably displaced because my guess is that they're making them nice and new and shiny and it's going to become higher income rent."

Based on participant observation, it seems that when $3 \mathrm{CDC}$ or other developers insist that they purchased vacant buildings, they seem to have blinders on and either truly do not see the value of the longtime residents who were displaced or are blind to the fact that the building became vacant after residents were moved out.

One such example is a building called Columbia on the corner of $13^{\text {th }}$ and Walnut. Notorious for its drug activity and crime, the building houses tenants, who will likely be displaced as the building is renovated. Speaking with a representative of the first developer who purchased the building, he described the litter in the hallways and the horrid conditions of the apartments. As someone who was displaced himself as a child, he 
said there is nothing wrong with displacement. In fact, he said, displacement was a positive thing based on his personal experience.

However, when I attended tenant meetings, the overall atmosphere was that of confusion, helplessness, anger, and fear. Those apartments were their homes and had been their homes for years. Residents asked why the building could not be rehabbed for them and why the police did not show up when called until after the building was purchased. They did not understand their rights as tenants. The developer held a community wide meeting to tell the existing residents about their development plans and how the residents would get relocation assistance. The room was filled with people to the point where it was standing-room only. The presentation was confusing and many residents left the meeting not understanding their tenant rights.

The building has since changed hands a couple times, and there seem to be no plans to put affordable housing units in the renovated building.

\subsubsection{The Displaced and Homeless}

"Some people see creating poverty as criminal. And some people see big money corporations, big money developers force people to lose their housing; some people see that as criminal, too." (Longtime resident)

During in-depth interviews with those that had been displaced and ended up becoming homeless at some point in their lives, it became clear how pervasive the problem of displacement can be. All the interviewees took responsibility for ending up in an unfortunate situation. Most blamed drug and alcohol related problems, which resulted in them being evicted. One elderly interviewee described how when she was displaced, 
she received no assistance, monetarily or administratively. Even when the interviewees sought to get out of homelessness, there were many impediments. As one formerly homeless interviewee described his situation,

\begin{abstract}
"But I have been...targeted because of my record. My record has actually passed. My record's been clean for like the past 8 years and people still talkin' about when I rent housing that they won't rent to me because of my record, my previous record. And I thought after 7 years, all that would be over with."
\end{abstract}

The only option for those making an income and trying to stay off the streets is to rent from slumlords who have a vested interest in letting their buildings fall into disrepair due to the ongoing gentrification. The interviewee described how even when one tries to get out of homelessness, it is very difficult to do so because "being homeless is complicated." He described how basic human needs such as hygiene and sleep were so difficult to come by. He explained how if one has to hold down a job which starts at 7:00AM but the shower house opens at 8:00AM and then there are 35 people in front of you, it makes it nearly impossible to get to work. Even though there are several social service organizations that cater to the needs of the homeless (for example, food pantries and shower houses), navigating the system successfully was still an impediment to holding down a job due to sheer logistics such as transportation constraints or finding a place to sleep at night.

During the course of my research, there was an ordinance passed that no longer allowed homeless people to sleep on the courthouse steps. The reasoning was that the homeless population was creating unsanitary conditions with defecation and urination near the courthouse steps. The Sherriff stated that the police will begin enforcement by asking the homeless to leave the courthouse steps, and that if they decline to do so, they 
will be arrested. The Homeless Coalition of Greater Cincinnati has since sued the Sherriff's department. As the Executive Director of the Homeless Coalition stated in an email dated October $17^{\text {th }}, 2013$,

\begin{abstract}
"Tonight, [the] Sheriff will have his deputies demand that people sleeping in front of the courthouse and justice center leave, threatening arrest if one does not leave. Tonight will be a very hard night for the men and women who found relative safety on this public land. People may be arrested; others will flee into alley ways, under bridges, in front of businesses, into abandoned buildings and other unsafe locations. Those who have slept at the courthouse and justice center will lose their safety in numbers. They will lose their ability to fend off possible attackers through numbers. Tonight is a sad night in Hamilton County. [The] Sheriff has decided to push people with nowhere safe to go even further into the margins. When people needed to be fed, clothed, visited and housed, [the] Sheriff will cast them away tonight."
\end{abstract}

When asked about the courthouse steps situation, a developer explained how he could see both sides but mentioned how creating a balance is difficult, and that he did not necessarily agree with the ordinance at this point. He also pointed out that the homeless did have options and chose not to use them. He did not provide any examples of such options.

The stricter police controls and resulting revanchism are reminiscent of the days of "Operation Vortex" in the 1980s when the police were aggressively cleaning up the streets which led to further marginalization of the poor and the homeless (Diskin and Dutton, 2006). Today, although the police have become more tolerant of the homeless population, there is still an underlying layer of mistrust. One homeless person recounted a story where he felt he was discriminated against for being homeless. He explained how he was cited (usually this means a ticket or an arrest) for drinking beer outside while the 
patrons of the bars on Vine Street were allowed to openly drink beer outside and were not cited for doing so.

While many of the more fortunate in our society believe that the homeless are homeless due to their own inaction, one formerly homeless interviewee described the crux of homelessness:

“Homelessness is like a no-way-out situation ... if nobody's going to help you. People say help yourself first and then people will help you...but then...I noticed my self esteem was very low...you have to have a concrete mind to be homeless 'cause it's enough to drive anybody crazy...I wouldn't wish it on my worst enemy."

\subsection{2. "People in the margins"}

One unexpected finding revolved around the question of homelessness and choice. Of the six displaced interviewees, two were homeless due to personal choice. One interviewee, a young white male, described how he was evicted from place to place and ended up migrating from Dayton to Cincinnati, and ultimately, to OTR. He described how much he loved OTR because there were so many service organizations to provide food and basic necessities. When asked where he slept at night, he said the key was to have several different spots so as to avoid police interference. He said he slept in alley ways, under the bridge, by the river and other places. He had no intention of joining one of the many programs geared toward getting people out of homelessness through rehabilitative supportive services and to ultimately finding housing. He said he needed a good all-purpose-weather backpack to carry his belongings. After the lunch interview 
was over, he said he had to rush to DF food pantry because they handed out sandwiches at 2:00PM.

The second interviewee was a female in her late 50s. She used to pay market rate rents but eventually became homeless. She lost custody of her three children and had been homeless for two and a half years at the time of the interview. She said she had never been happier in her life. She described how she felt a greater sense of spirituality and community which she had never experienced before. She explained how she did not have a mental illness or a substance abuse problem, which meant she could not take advantage of many of the social service programs. But, she refused to get on food stamps because of the many people who abused the system. She said she had not received any governmental assistance for five years and did not plan on applying for it. At the time of the interview, she was writing a memoir of her life story and spirituality, using the local library computers. She described that her next step would be to get her GED and then to go back to school to become a social worker. When asked about finding housing, she said it would happen in a month because "the Lord only gives you as much as you can handle."

All displaced interviewees said they were humbled and found a resiliency that they did not know they possessed. One interviewee explained how he felt a sense of relief because he had hit rock bottom and how he had anticipated the worst and now that it had happened, he knew he could make it through other adversities in life. Along with a sense of empowerment, all interviewees described an increase in their level of spirituality. They also described finding a strong community of brethren who helped each other and looked out for one another. 


\subsection{Revitalization vs. Gentrification}

The term gentrification has many negative connotations, in particular, the concept of displacement. When conducting in-depth interviews, it was easy to determine whether the interviewee was pro-redevelopment or anti-redevelopment by listening to the language that they used. Proponents referred to redevelopment as "revitalization" or even "a renaissance" while opponents simply chose to use the word "gentrification."

When asked specifically about the term gentrification and what it meant within the context of OTR, some interviewees laughed outright. Unexpectedly, a longtime resident took offense to the term and to the study itself when she said,

"So when you called and said I'm doing a report on gentrification, that was a slap. We're not gentrifying. We are not asking anyone to move out...nobody is being forced out; we are simply filling in the vacancies around them in a way that hopefully connects people and raises the level of living for everybody."

When asked why people used the term gentrification, she believed that it was essentially a bad case of semantics,

"I think it's ignorance. I don't mean stupid; I just mean not being familiar with the term that they're using and what's really going on. I think if you wanted to do a quick label, that's a word that you grab. It's got a lot of punch, that word does right now, it's got a lot of punch. So if you wanted to get a headline, or if you wanted to get some attention, you know it's a word. It's not the right word."

She went on to describe how one of the developers builds affordable housing in addition to market rate housing. Upon completion of the units, the original, low-income residents have the option to move back in (albeit with stringent requirements and background checks). 'It's not that they can't come back in, it's because they choose not 
to come back in," she said. This particular developer declined to meet with me for an interview so I was unable to get any further details on such situations.

One developer answered by saying, "I don't believe in gentrification and I also don't believe in displacement." Other, primarily corporate interests were softer in their approach and saw gentrification as a positive phenomenon, especially because it creates a mixed community. As some interviewees described it,

"It's a buzz word. I don't think it's healthy for any community to lack diversity...if gentrification mixes poor, affluent, black and white, what's wrong with it?"

"From a utilitarian point of view, more good is being accomplished than bad."

"There is some gentrification, there's no doubt about that but I don't think in this particular situation, it's a bad thing. I don't think gentrification has to be a bad thing. OTR has certain buildings...that will always be subsidized. And then you have market rate. Everybody gets along...it's a diverse culture...you have to have a mix."

A longtime resident also described how the term was now being used in a positive manner,

"And gentrification now is a term that people use in the positive. I heard it used in a positive way...people knew it was a pejorative term...but I heard it...on the radio [on NPR]. It wasn't about this community but it was just in general. 'oh yes, the gentrification of da-da-da...it does all this greatness, it does all these wonderful things'... and so there's a movement afoot to embrace the term and say yeah, that is what we're doing."

A representative of the city commented on the complexity of the concept by saying,

"When you say something like gentrification, that just makes it so simple and clean; good and bad. It's not like that. 
I think the term gentrification was an easy way to paint with a broad brush... and usually it was done by the social service folks that were getting paid to kind of guard their turf...you say it's complex because it's in the context of a simply framed argument when the argument should never be framed that way."

Another interviewee had a similar response when he said "as a historian, I kinda see that as an un-useful term because it denies the fact that through time you get these ebbs and flows of economic development."

When newcomers were asked about the term gentrification within the context of OTR, the responses were mixed. Some newcomers believed that in OTR, the demographic change could not be described as gentrification because they did not personally know of anyone getting displaced. A newcomer described how when squatters are removed from abandoned buildings that are then renovated, "[he did not] think that renovating that building they were in was gentrification. [He believed that] that was saving a building... and facilitating the process of those people finding housing that wasn't third world...developing country.”

Another newcomer did believe that the revitalization was, in fact, gentrification.

She was almost apologetic when she described her experience.

"It does bother me that the neighborhood's become so gentrified, even though I know I'm part of the problem by moving down here and inflating the rents and driving lower income people out...I try to become part of the neighborhood...because I know I'm part of this influx of new money into the neighborhood. I wanna be the example like look, we're not here to run you out of your homes; we wanna just be a part of the neighborhood. It is part of the authentic experience I wanna have."

With the exception of the previously mentioned longtime resident, when other longtime residents were asked about the term, as anticipated, their responses were on the 
other end of the spectrum. One longtime resident explained the distinction between the terms as follows:

"I hate the term revitalization... 'cause it's always about money. This was a very vibrant neighborhood in 1968; just didn't have any money. People kept talking about revitalizing it all...we're not dead...thousands of people lived here...give us money and we can revitalize...but no, they don't want to do that... just move people out...spray paint it...bring new people in."

He then went on to say how the revitalization in one neighborhood occurs at the expense of other neighborhoods as "people move with their problems elsewhere." He explained how current policies “don't help people solve their problems...don't invest in people as they invest in the buildings."

A representative of a social service organization had a more comprehensive and nuanced definition of the term gentrification when he said,

"Gentrification is an interesting word. And depending on the individual you talk to, it can be an enlightening, educational kind of concept to discuss; it can be a motivational concept from which to protest, or to move, or to get socially active or politically active. It can be a concept to bury and to hide and to work against in order to achieve your aims, your ends, you goals for building and construction. And so it really depends on your purpose, your intent and who you are and what you're doing as to what that word means, whether it's positive or negative or somewhere in between."

As Marcuse (1985) points out, gentrification can take two different forms: direct and indirect. A representative of a social service organization explained how gentrification in OTR took three different forms,

"The ground level of gentrification for us probably has two different parts; one is often a group like 3CDC will come in to kind of a mom-andpop landlord who owns one to three buildings... and says to them 'hey, your building needs some work.... we'll buy it from you and we'll give you 
a profit on it.' Some people say 'no, I'm not interested' and other people, it's a big deal for them and they have the conversation and then the company can say 'well, we will buy it from you but the only way is if you get everyone that is in there out.' And so then that landlord can put up the rent or find some other way of evicting people and the company who bought it says 'well, we never evicted anybody.'

The other means would be that they actually themselves do buy directly and kick people out or probably a third is more indirect that they take off, take over all the commercial space, run out local businesses that benefit the neighborhood; run out the places people use and make it hard to live here...that would be the indirect gentrification."

Based on participant observations, focus group interviews, in-depth interviews, and subsequent analysis, it seems that in OTR there has been a significant amount of indirect gentrification. Over the past few years, many mom-and-pop stores catering to the needs of low income residents have closed down - either due to political pressure or economic pressure - it is difficult to determine. One example that kept coming up was the fact that there was no longer a laundromat in OTR which worsened the bed-bug problem in the subsidized housing units. As one longtime resident described it,

"gentrification is purposefully closing those businesses [mom-and-pop stores]. So the Laundromat that would be supported and...low income people that would go there because it existed...now they have to drive up to Clifton. So it isn't here, not because of the need...but it's not the kind of business that they want to have on Vine Street.

They want a bar, a hoity-toity restaurant and some knick knack shop. And that's the three things, if you don't fit that, you're not going to get a business there. There was a wig shop that was on the corner; right now it's a bar...the wig shop didn't go out of business - it moved. Plenty of corner stores are now closed because of the people hanging out in them. And then they are replaced with art galleries and other things that don't service anybody or hardly anybody. So it isn't a factor of just a shrinking community and lack of demand, it is purposeful lack of wanting those businesses to exist in this neighborhood." 
The overarching sentiment amongst longtime residents is that even if they wanted to patronize the new bars, restaurants, art galleries, and other establishments, it would be very cost-prohibitive for them to do so. One longtime resident went a step further and implied that this was an intentional tactic when he said, "And I think that's what it is, they want to make the neighborhood unaffordable to low income people."

Whether this longtime resident's assertions are true or not, there still remains enough evidence of indirect gentrification. The increasing rents and the diminishing services are leading to a tangible form of displacement. It is very difficult to track displacement, however, there are many anecdotal stories speaking to a very real phenomenon of gentrification.

If we were to revisit the definition used by Lees et al. (2008), and further operationalized in this dissertation, there are four parts to consider. Lees et al. (2008) record the key elements of gentrification as follows:

1. The reinvestment of capital

2. The social upgrading of locale by incoming high-income groups

3. Landscape change

4. Direct or indirect displacement of low-income groups In the case of OTR, my findings suggest that there is, in fact, indirect gentrification, and not revitalization, that is taking place. There is a significant amount of capital that is being invested into the redevelopment of OTR (economic restructuring). The funds primarily come from 3CDC, the city, and the corporate community. There has certainly been an increase in homeownership rates as a more affluent class moves into the neighborhood (social reconfiguration). 
In order to attract the middle- to upper-middle income residents to OTR, there has been substantial change to the landscape as the old Italianate buildings are gutted and rehabbed (physical transformation). Finally, although difficult to track, there are a plethora of anecdotal accounts that speak to the displacement that has occurred and will continue to occur.

As redevelopment in OTR continues at a rapid pace, the city's neoliberal agenda is being realized via a "back to the city" movement by the middle- to upper-middle class. The city, 3CDC, the developers, and the corporate community are providing the necessary structure to ensure that gentrification, under the guise of revitalization, continues to occur. The longtime residents, social service organizations, and advocacy groups have been side-lined as they are either not involved or not listened to during redevelopment plans. The displacement of longtime residents is also weakening their voice and decision-making power. This "top-down," developer-driven redevelopment process is witness to a devolution and privatization of state power. The changing constitution of OTR, physically, economically, socially, and politically, is a testament to a dilution of the democratic process and the city's accountability to its citizens.

The city claims that it is realizing an increase in tax receipts. However, approximately $50 \%$ of new homeowners moved from within the city, undermining the city's claim of increased revenues. There are increased revenues; however, the indigent population is not benefiting monetarily in any way (for example, via additional jobs). Instead, it is a select group of people, such as the new businesses and the developers, and all the parties (lawyers, syndicators, to name a few) involved in the "deal", that can claim profits. The indigent population is not realizing the social benefits from the 
redevelopment and is instead bearing the bulk of social costs associated with the redevelopment.

The next concluding chapter summarizes key findings and then discusses the significance of this study, with special emphasis on policy issues and recommendations, limitations of the study, and areas for further research. 


\section{CHAPTER 6}

\section{CONCLUSION}

The goal of this study was to determine the social costs and benefits of gentrification using qualitative methods in a case study format. Qualitative methods were used to gain a deeper understanding of the gentrification process. By interviewing all the actors in the process, from city officials, to $3 \mathrm{CDC}$, to developers, to social service organizations, to newcomers, to longtime residents, and to the displaced and homeless, I was truly able to gain a holistic understanding of the social costs and benefits of gentrification through multiple lenses. The study was informed by existing scholarly literature on gentrification and framed by the overarching research questions presented in Chapter 1 and again in Chapter 3. The research questions are as follows:

1. What is the rationale for redeveloping Over-the-Rhine?

2. What are the relationship dynamics amongst various actors in the redevelopment efforts?

3. Who has decision making power?

4. What are the perceived social costs and benefits of gentrification?

Each umbrella question is further analyzed in Section 6.1. 
Chapter 2 turned to existing literature on gentrification. It first discussed the social production of space, with particular emphasis on how and why uneven development occurs and space becomes a commodity. Next, it delved into the definition and explanations of gentrification, situating it within a historic context. It then discussed the political, economic, and social factors shaping gentrification today, with particular emphasis on the various actors that influence redevelopment.

The political dimension focused on how the role of the state has changed over the past few decades, particularly with reference to urban renewal. As the focus for cities has shifted to economic development, the government's role has morphed from being a regulator of development to a facilitator of development. Such facilitation has occurred using tools such as tax subsidies and public-private partnerships, thereby spurring gentrification in disinvested urban neighborhoods. The economic dimension focused on the inter-relatedness between global capital and gentrification. In OTR, gentrification has become a very developer-driven process with financial backing from the city and corporate community. Thus, economic development decisions rest in the hands of the business elite, with longtime residents having very little to no voice in the development plans.

The social dimension focused on resistance movements, beginning with the most renown and well-documented violent clash at Tompkins Park Square in Lower East Side in 1988. Scholarly literature finds that anti-gentrification resistance movements have weakened in scope, although they still exist in many communities (Hackworth, 2002; Fainstein and Fainstein, 1991; Lees et al., 2008). This diminished power is due to the displacement of core activists (reducing the voice of the group) and greater difficulty 
coordinating community organizing in a neoliberal state (DeFillipis, 2004; Newman and Lake, 2006; Lees et al. 2008).

The chapter concluded by enumerating the costs and benefits of gentrification. Scholarly literature finds that the greatest cost of gentrification is displacement (LeGates and Hartman, 1981, 1986; Lyons, 1996; Newman and Wyly, 2006) and the erosion of social capital. The greatest benefits include increased tax revenues, social mixing through the de-concentration of poverty, and a general upgrading of the disinvested neighborhood.

Chapter 3 first provided details on the site chosen the case study, Over-the-Rhine. It then provided a framework of analysis via a discussion of the overarching research questions. These questions centered around the who, why, and how of gentrification. As such, a case study was most suitable to gather rich data. OTR was chosen as the site for the case study because it has often been described as a prototype for gentrification in scholarly literature (Addie, 2008; Dutton, 2007; Maag, 2006; Miller and Tucker, 1998; Scheer and Ferdelman, 2001; Smith and Faegin, 1995; Waymer, 2012; Wyly and Hammel, 2004). The gentrification taking place in OTR is a very state-driven, developerdriven process, with the decision-making power resting solely in the hands of the business elite. Although there has been much research done on OTR, nobody has studied the social costs and benefits of gentrification using a qualitative approach.

The research questions and interview questions were structured to explore the dynamics of the gentrification process and gain insight into the complex web of actors and activities that facilitate the process. Furthermore, the open-ended format of 
interviews, participant observation, a focus group, and print media illuminated the nuances of the social costs and benefits of the process. The interviewees included all the actors involved in the gentrification process and were identified using snowball sampling and systematic random sampling methods. By utilizing the responsive interviewing model, it was possible to gain a deeper understanding of the gentrification process from multiple lenses.

Chapter 4 discussed the findings of the study, first providing a context for the case study. It then discussed the impact of redevelopment on various segments of society: longtime residents; newcomers; and social service organizations. Understandably, while the newcomers, developers, $3 \mathrm{CDC}$, and city officials were excited about the redevelopment efforts, the longtime residents, social service organizations, and advocacy groups feared the reality of potential displacement. Therefore, OTR has become a very divided community. The chapter further delved into the interactions between newcomers and longtime residents as well as those between the corporate community and the social service organizations. While civil, the interactions were strained and perfunctory at best.

Chapter 5 presented an analysis of gentrification in OTR, with particular emphasis on the social costs and benefits of the process. It gave insight into the phenomenon of displacement and those that have been displaced or are currently homeless. Some unexpected findings included benefits such as a "trickle-up" effect, in which the benefit accrues to the more affluent newcomer rather than the "disenfranchised" indigent individual. Other unexpected findings included the fact that all displacees felt a sense of empowerment and a greater sense of spirituality after experiencing the hardships of displacement. The chapter concluded with a discussion of the distinction between the 
often interchangeable terms 'revitalization' and 'gentrification.' As the interviewer, I had to be careful about my word choice, especially when it came to the politically charged terms 'revitalization' and 'gentrification.' It was easy to determine whether the interviewee was a proponent or an opponent of redevelopment by simply listening to their word choices. Proponents used the words 'revitalization,' 'urban renewal,' and even 'a renaissance,' while opponents chose to simply use the word 'gentrification.'

This chapter summarizes key findings, discusses the significance of the study with special emphasis on policy recommendations, its limitations, and areas for further research.

\subsection{Summary of Findings}

The following section revisits the umbrella questions that shaped the study.

\section{What is the rationale for redeveloping Over-the-Rhine?}

Today, the redevelopment taking place in OTR is the product of political, social, and economic factors, molding inner-city development according to a planned agenda. OTR's valuable location between the Central Business District to the south and the medical and university community to the north makes it ripe for redevelopment. My findings suggest that the revitalization that is currently taking place in OTR is a classic case of gentrification. The fact that $3 \mathrm{CDC}$ exists and is redeveloping OTR in such a methodical, strategic manner is consistent with the change in the form of gentrification itself. In the decades prior to 2000 , gentrification was an organic process, where artists 
moved into a disinvested neighborhood due to the low rents and upgraded the housing stock, attracting other artists, and ultimately pushing the original residents out due to increasing property values and rents. Today, gentrification has become a systematic, strategic, and deliberate state-driven process, as witnessed in OTR.

\section{What are the relationship dynamics amongst various actors in the redevelopment} efforts?

The relationships between the various actors can be described as being cohesive and strained at the same time. Proponents of redevelopment include city officials, 3CDC, the developers, the corporate interests, and the newcomers. Opponents of redevelopment include the longtime residents, social service organizations, advocacy groups, and the displaced and homeless. There is a strong sense of divisiveness within the community.

The qualitative methodology used provided for a much deeper understanding of gentrification from which to draft better policy solutions. For example, through snowball sampling, it was easier to gain a better understanding of the interactions between newcomers and longtime residents - an antagonistic situation that could easily be remedied through concerted efforts at community building. I was also able to give voice to those that had been displaced. Grounded in "lived reality," I was able to truly understand what is meant by "social capital," the erosion of which leads to increased costs such as an increased need for social services or, worst case scenario, the increased costs associated with homelessness.

The form in which redevelopment occurs promotes and exacerbates cultural alienation among the longtime residents and the newcomers. There appear to be two 
separate communities within one neighborhood. While newcomers are attracted to the "diversity" in OTR, they fail to integrate within the existing community. The relationship between the two groups, though civil, is extremely tense, as is most visible in the OTR Community Council meetings. The pro-redevelopment groups currently hold all decision making power, leaving the rest of the community feeling vulnerable and voiceless.

3. Who has decision making power?

The development currently underway is spearheaded by 3CDC, with financial and political backing from the city and the corporate community. The creation of 3CDC itself speaks to the fact that the city of Cincinnati has adopted a neoliberal agenda. The devolution of state power has resulted in policies that promote gentrification. Since 3CDC's board primarily consists of representatives from major corporations in Cincinnati, the decision-making power rests in the hands of elite interests. The neoliberal agenda devalues the democratic process, not giving voice to those most affected by gentrification. By ignoring the reality of displacement, the city is further marginalizing its low-income population. As a key informant put it,

\footnotetext{
"Instead of wanting to look the other way, Cincinnati needs to acknowledge, 'hey, we're displacing people, and it's going to cost somebody some money. We get a federal grant, a state grant, we increase payroll taxes so that we can pay for that,' you know... we resist collective solutions, so right now we have part of a policy that says gentrify, and no policy that says here is how we need to address the consequences of that to protect everybody; to make sure that it's win-win for everybody... because there's no compelling argument for maintaining a neighborhood where the crime rate's always going to be high; where the children are too early exposed to sex and violence; that most of the kids are going to drop out of school. The just-to-maintain a ghetto policy is absurd and to try to wipe it out overnight is even more absurd."
} 


\section{What are the perceived social costs and benefits of gentrification?}

By utilizing the responsive interviewing model, I was able to gain a very nuanced understanding of the social costs and benefits of gentrification, as presented in Chapter 5 . The interviewees mentioned that safety and the redevelopment of Washington Park (which promotes social mixing) were the most tangible benefits. There were also other social benefits in the form of landscape beautification, an upgrading of utilities, and an increase in home ownership and civic pride.

An unexpected finding, not presented in existing literature, was the positive "trickle-up" effect from social mixing. Byrne (2003) discusses the positive "trickledown" effects, however, existing literature does not point to any positive trickle-up effects. It is also interesting to note that opponents of redevelopment had a difficult time answering the question and were not able to see any social benefits beyond beautification.

The most noticeable social cost was displacement of social service organizations, mom-and-pop stores, and longtime residents. Thus, the indigent population was the only population losing their social support networks. They were also the only ones not gaining monetarily from the redevelopment in the form of new jobs or increased opportunities. As the demographics of the place change, the very essence of the neighborhood is changing. Also, via displacement, there is instability in the new neighborhoods creating angst between other neighborhoods and OTR. Just as the opponents of redevelopment could not see any social benefits, most of the proponents were not able to see any social costs. 
Another unexpected finding revolved around the questions of homelessness and choice and disenfranchisement and empowerment. While existing literature points to the displaced being voiceless and helpless, two of the six displacees interviewed in this study were homeless due to personal choice. Displacees are also presented as being powerless. However, all the interviewed displacees said they were empowered, felt resilient, and more spiritual after being displaced. One of them also said that she had never been happier in her life.

The next section discusses the significance of this study, with special emphasis on policy recommendations.

\subsection{Significance of Study}

This dissertation adds to existing literature by illuminating the social costs and benefits of the gentrification process using a qualitative methodology, which will enable cities to draft better policy solutions.

Gentrification is occurring in many cities. By undertaking a social cost-benefit analysis, a city can understand true costs such as an increase in resources to stabilize adjacent neighborhoods, and take policy actions to mitigate these negative realities of gentrification. Cities that are considering revitalizing their urban core areas need to gain a holistic tally of the costs and benefits of such an undertaking by going beyond just a profitability analysis. A qualitative assessment presents an economic understanding by going beyond the numbers and incorporating the social costs and benefits of the process. 
OTR should be used as a prototype, not for successful revitalization, but instead, as a learning lesson for what can be done better. I think before a city undertakes a revitalization project, it needs to very carefully consider creating or changing policy so that the new community is a truly mixed-income, integrated community. As such, the next section presents some policy recommendations for Cincinnati as well as other cities that are considering revitalizing their urban core.

\subsubsection{Policy Recommendations}

Cincinnati has methodically adopted policies to attract the middle- to uppermiddle class back to the city in order to improve its tax base. There are no policies in place that protect the low-income population that is getting displaced. I believe that it is possible for a city to revitalize its urban core while protecting its marginalized citizens by carefully assessing its current policies and creating policy solutions that mitigate the negative consequences of gentrification. A case in point, as mentioned before, is the neighborhood of Prenzlauer Berg in eastern Berlin, where revitalization occurred in a much more balanced way by focusing on "community participation, local job creation... and forming partnerships among churches, charities, and community-based associations" (Levine, 2004, p. 104).

When drafting policy, the first question to consider is 'who benefits?'. Current policy only benefits the city, $3 \mathrm{CDC}$, the developers, the corporate community, and the newcomers. The longtime residents, social service organizations, and the displaced and 
homeless have been left out of the equation. In order to create a more equitable, balanced approach to revitalization, I propose the following policy recommendations.

Just cause eviction laws protect renters by ensuring that landlords can only evict with proper cause. Cities, such as New York, San Francisco, Chicago, LA, DC, New Jersey, and Seattle, to name a few, have adopted just cause eviction laws and have a detailed list of reasons for just cause eviction, the most obvious being failure to pay rent or destruction of property (Greater Cincinnati Homeless Coalition). Landlords who fail to comply face strict penalties. Compliance must be monitored by a government agency; for example, in San Francisco, it is the San Francisco Rent Board.

Rent control policies, often used in conjunction with just cause eviction policies, protect tenants by ensuring gradual rent increases. Today, rent control policies exist in 140 jurisdictions (Ibid.). Both just cause eviction and rent control, especially when used together, stabilize the rental market, increase tenant stability, prevent rapid rent increases, and ultimately stabilize the entire community. It is also a deterrent to displacement and ensures that longtime residents can also enjoy the increased standard of living that is the goal of revitalization. It also helps toward creating a sustainable mixed-income community.

Resident stock ownership in CDC projects is an emerging strategy that is currently being explored by several CDCs around the country. While not yet fully implemented, the program would provide low- income/low-wealth residents the opportunity to invest in neighborhood commercial real estate projects carried out by CDCs (PolicyLink). 
Ownership in CDC projects gives residents a vested interest in economic development activities in their communities. It gives them a voice in the development process and gives them the opportunity to play a new role: one of stakeholder, shareholder, and partner with the CDC and other investors. As community assets appreciate, the residents' assets also appreciate. This leads to greater family security while at the same time building a mixed-income community. Most importantly, it creates a mutual desire for economic development amongst the longtime residents and the corporate community (Ibid.).

There is a strong push for Cincinnati to adopt an anti-displacement policy. In fact, one of the incumbents for City Council, Mike Moroski, ran on this platform. According to him, anti-displacement policy accomplishes four major goals:

1) discourages slum lording,

2) protects and increases the city's affordable housing stock,

3) promotes more equitable development in all 52 neighborhoods, and

4) increases the safety of everyone in the City: In his words,
"when more people are housed, there is less crime - when there is less crime, there are less people in prison - when there are less people in prison, there are more people participating in the economy and everyone is better off for it."

An anti-displacement ordinance however has been discussed since the early 1990s but has not passed muster because of political opposition. 
An inclusionary zoning program is essentially a tax on new housing

development; developers are required to provide a proportion of housing units at a belowmarket rate price, which is only sometimes partially offset by government-subsidies. At the below-market price, the developer will either lose money or accept a reduced profit by building those units, making it a somewhat controversial tool (Dietderich, 1996).

Another option may be to require a one-for-one replacement or a percentage of funding received by the developer to be set aside for affordable housing.

There are also some "softer" approaches that the city and 3CDC can undertake. Certainly, there needs to be greater communication and inclusiveness in the development plans. The city or $3 \mathrm{CDC}$ can implement community wide meetings so that everyone is working toward mutually beneficial goals. Garnering support from local churches, social service organizations, charities, and community-based organizations would go a long way towards reducing tensions between the "haves" and the "have-nots." Creating a transparency in process and having open dialogue between all members of the community would ensure a more democratic process that gives voice to every citizen, regardless of her socioeconomic status. Open communication also provides for an educational opportunity as each side learns more about the motivations of the other. It is also critical to develop a skilled labor force through job training programs. This task can be undertaken by the city or by $3 \mathrm{CDC}$. Additionally, the city could require new businesses to hire a certain percentage of their workforce from the local population. This would lead to additional job training, and make sure that some of the new wealth is captured by the local residents. 
Additionally, there is a need for social service organizations geared toward helping those without substance abuse issues or mental health problems. This would reduce some of the homelessness. A displaced person gave an example of a boyfriend being kicked out of the home he had been sharing with his girlfriend. If he did not suffer from a mental illness or substance abuse issues, he would not be able to take advantage of the social service programs that are currently available. If there were such supportive services available, it would be a good means to reduce some of the homelessness.

Moreover, there is an acute need for supportive services for those that have been displaced. Comparable access to social services would improve the lives of the lowincome population, reducing some of the stress associated with moving. It would also be very beneficial to factor in commuting distances to the workplace, ensuring retention of employment. This could perhaps be accomplished via bus vouchers, or some other form of subsidized transportation.

Of the previous policy recommendations, it would be very advantageous for the city of Cincinnati to adopt just cause eviction and rent control policies, immediately stabilizing the neighborhood and reducing displacement. This will not only benefit the existing residents of OTR, it will also have a wider stabilization effect on adjacent neighborhoods. Furthermore, it will also ensure a truly mixed-income community. However, it is important to note that, in OTR, the positive impacts of such policies will be limited due to the high vacancy rates $(62.8 \%)$.

It would similarly be easy for the city to adopt policies requiring developers to set aside a certain percentage of subsidies for affordable housing or have a one-for-one 
replacement policy. This would not only offset some of the costs from developer subsidies, but also reduce costs associated with homeless. I also strongly propose that the city consider resident stock ownership programs. Doing so immediately makes economic redevelopment a mutual goal for the longtime residents and the corporate interests, reducing the existing divisiveness within the community. This could be accomplished by the issuance of vouchers to longtime residents who meet certain criteria (such as incomelevel, employment, number of dependents, length of residency in OTR, background checks, and an agreement to forfeit the voucher if the resident moves out of OTR, to name a few), for investment into 3CDC capital projects. Since displacement is occurring, the city needs to make certain that they are providing the necessary supportive services for the displacees.

\subsection{Limitations of study}

There are inherent strengths and weaknesses to the case study format. Weaknesses include the sheer amount of data that needs to be analyzed. For this study, there were approximately 90 plus hours of non-stop interviews that needed to be listened to, analyzed, thematically organized, and interpreted. Another limitation is that the complexity of the data is difficult to express simply. The data does not lend itself to numerical representation and is not generalizable in the conventional sense. There are also doubts about objectivity, preconceived notions, and interpretation by the audience.

There are also many strengths to the case study format. It can help us understand complex, inter-relationships that facilitate a rich understanding of the phenomenon. Case 
studies are grounded in "lived reality" which facilitates a deeper exploration of complex issues. The depth and complexity of case study data can illuminate the ways in which such correlated factors influence each other. And, case studies can be transposed beyond the original site of study.

Sample size: Some might argue that the sample size is a limitation. However, in this study, I did reach a point of theoretical saturation.

Displaced residents: It is very difficult to track down displaced residents because once moved, it breaks their social networks. Addresses and phone numbers change, making it very difficult to track down the displacees. If this study were to be attempted at a larger scale, it would be very difficult to track down those that have been displaced.

\subsection{Areas for Further Research}

While this study adds to the literature by presenting an economic tally of the social costs and benefits of gentrification, it can be taken one step further by incorporating a social accounting approach. Social Benefit Cost Analysis (SBCA) can be used to monetarize the "intangibles," further buffering a traditional Cost Benefit Analysis (CBA). SBCA measures the impacts of the project on society as a whole by utilizing an accounting of public costs and benefits in addition to traditional costs and benefits. By utilizing SBCA, one can monetarize the costs of displacement and homelessness as well as the benefits of beautification and increased safety, determining whether the true benefits exceed the true costs of revitalization. 
Another area for future research may include a case study of the Columbia building on the corner of $13^{\text {th }}$ and Walnut (previously discussed in Section 5.3). It was recently purchased by developers for renovation. The building houses tenants who will likely be displaced as the building is renovated. By following the renovation and relocation process through a qualitative study, one could gather rich data from the future displacees, in addition to the developers, 3CDC, the city and other actors involved in the project. Such a study would also enable me to further delve into the concepts of displacement and empowerment, which was an unexpected finding in this study. Moreover, it will provide some means to track displacees, an inherent shortcoming of gentrification-related studies.

A third area of interest is the changing constitution among CDCs and its implication on community development. As is to be expected in a gentrifying neighborhood, there is a very large anti-redevelopment sentiment among the longtime residents. By default, this means that the advocacy group is against the CDC since it plays the role of main developer. This almost seems antithetical to the traditional function of a CDC where it acts as a liaison between the community and the city. As CDCs adapt to changing political environments, it would be very interesting to study which approach - top down (city initiated) or bottom up (citizen initiated) - is most useful to the health of a city and its citizens.

Another striking phenomenon is the existence of acute homelessness amongst a bevy of vacant buildings. It would be very useful to draft policy solutions that mitigate the ill-effects of vacancy and provide housing for the homeless. As such, another aspect 
of my research would focus on the relationship between vacancy rates and homelessness, with particular emphasis on policy solutions. 


\section{REFERENCES}

Addie, J. D. 2008. "The Rhetoric and Reality of Urban Policy in the Neoliberal City: Implications for a Social Struggle in Over-the-Rhine, Cincinnati." Environment and Planning A 40: 2674-2692.

Atkinson, R. 2002. "Does gentrification help or harm urban neighborhoods? An assessment of the evidence-base in the context of the new urban agenda." ESRC Centre for Neighbourhood Research paper 5 (http://www.neighborhoodcentre.org.uk/research/cnrpaperspdf/cnr5paper.pdf).

Beauregard, R.A. 1986. "The chaos and complexity of gentrification" in Gentrification of the City (eds.) N. Smith and P. Williams. London: Allen and Unwin, pp. 35-55.

Beauregard, R. A. 1990. "Trajectories of neighborhood change: The case of gentrification." Environment and Planning A 22: 855-874.

Bell, D. 1973. The Coming of Postindustrial Society: A Venture in Social Forecasting. New York: Basic Books.

Black, N. 1994. "Why we need qualitative research." Journal of Epidemiology and Community Health 48, no. 5: 425-427.

Blomley, N. 2004. Unsettling the City: Urban Land and the Politics of Property. New York: Routledge.

Bourassa, S.C. 1993. “The rent gap debunked.” Urban Studies 30, no. 10: 1731-1744.

Brenner. 1998. "Between fixity and motion: accumulation, territorial organization and the historical geography of spatial scales." Environment and Planning D: Souciety and Space 16, no. 5: 459-481.

Brown-Saracino, J. 2010. The Gentrification Debates. New York: Routledge.

Bryer, R., S. Brignall and A. Maunders. 1984a. "The Origins of Plant Closures in U.K. Manufacturing Industry," in Fighting Closures (eds.) H. Levie, D. Gregory and N. Lorentzen. Nottingham: Spokesman. 
Bryman, A. and R.G. Burgess (eds). 1994. Analyzing Qualitative Data. London: Routledge.

Buechler, S. M. 2000. Social Movements in Advanced Capitalism. Oxford: Oxford University Press.

Burawoy, M. 1983. "Between the Labor Process and the State: the Changing Face of Factory Regimes under Advanced Capitalism.” American Sociological Review 48, no. 5: 587-605.

Burgess, E. 1925. "The Growth of the City: An Introduction to a Research Project." In Park, Burgess, and McKenzie, 1925.

Butler, T. 1997. Gentrification and the Middle Classes. Aldershot, UK: Ashgate.

Byrne, J.P. 2003. "Two cheers for gentrification." Howard Law Journal 46, no. 3: 405432.

Cameron, S. 2003. "Gentrification, housing redifferentiation and urban regeneration: 'Growing for Growth' in Newcastle upon Tyne." Urban Studies 40, no. 12: 23672382.

Castells, M. 1977. The Urban Question. London: Edward Arnold Publishers Ltd.

Caulfield, J. 1989. "Gentrification and Desire." Canadian Review of Sociology and Anthropology 26, no. 4: 617-632.

Caulfield, J. 1994. City form and Everyday Life: Toronto's Gentrification and Critical Social Practice. Toronto: University of Toronto Press.

Chaskin, R. J. 1997. "Perspectives on Neighborhood and Community: A Review of the Literature.” Social Service Review 71, no. 4: 521-547.

Chernoff, M. 1980. Racial displacement in a Renovating Neighborhood's Commercial District: Atlanta" in Back to the City: Issues in Neighborhood Renovation (eds.) S. Laska and D. Spain. Oxford: Pergamon Press, pp. 204-219.

Cincinnati Center City Development Corporation. "OTR Work Group Reports." Accessed February, 2014. http://www.3cdc.org/3cdc-in-the-news/otr-workgroup/.

Clark, E. 1988. "The rent gap and transformation of the built environment: Case studies in Malmo, 1860-1985." Geografiska Annaler B 70, no. 2: 241-254. 
Clark, E. 2005. "The order and simplicity of gentrification: A political challenge" in Gentrification in a Global Context: The New Urban Colonialism (eds.) R. Atkinson and G. Bridge. London: Routledge, pp. 256-264.

Clawson, M. 1959. "Methods of Measuring the Demand for and Value of Outdoor Recreation." U.S. Resources for the Future, Inc. Washington, DC. Reprint No. 10.

Clay, P. 1979. Neighborhood Renewal: Middle-Class Resettlement and Incumbent Upgrading in American Neighborhoods. Lexington, MA: Heath.

Comte, A. 1875. System of Positive Policy. New York: Burt Franklin.

Covington, J. and R.B. Taylor. 1989. "Gentrification and crime: robbery and larceny changes in appreciating Baltimore neighborhoods during the 1970s." Urban Affairs Quarterly 25, no. 1: 142-172.

Davidson, M. 2008. 'Spoiled Mixture: Where Does State-led 'Positive' Gentrification End?." Urban Studies 45, no. 12: 2385- 2405.

Davidson, M., and L. Lees. 2005. 'New-build 'Gentrification' and London's Riverside Renaissance.” Environment and Planning A 37: 1165-1190.

DeFilippis, J. 2004. Unmaking Goliath: Community Control in the Face of Global Capital. New York: Routledge.

Dierderich, A.G. 1996. “An Egalitarian's Market: The Economics of Inclusionary Zoning Reclaimed.” Fordham Urban Law Journal 24, no. 1: 23-104.

Dey, I. 1993. Qualitative Data Analysis: A User Friendly Guide for Social Scientists. London: Routledge.

Diskin, J., and T. A. Dutton. 2002. "Cincinnati: A Year Later, and No Wiser." NHI Shelterforce One, Issue 123.

Diskin, J., and T. A. Dutton. 2006. "Gentrification- It ain't what you think." Working Paper. Miami University Center for Community Engagement in Over-the-Rhine.

Domah, P. and M.G. Pollitt. 2001."The Restructuring and Privatization of Electricity Distribution and Supply Businesses in England and Wales: A Social Cost-Benefit Analysis." Fiscal Studies, 22, no. 1: 107-146.

Dutton, T. A. 2010. "District 9: Over-the-Rhine- Working Paper." The Cincinnati Beacon, May 19, 2010.

Eckstein, O. 1958. Water Resource Development. Cambridge, MA: Harvard University Press. 
Estes, R. 1976. Corporate Social Accounting. New York: John. Wiley \& Sons.

Fainstein, S. and N. Fainstein. 1991. "The changing character of community politics in New York City: 1968-1988.” In Dual City: Restructuring New York (eds.) J. Mollenkopf and M. Castells. New York: Russell Sage Foundation, pp. 315-332.

Foster, C.D. and M.E. Beesley. 1963. "Estimating the Social Benefit of Constructing an Underground Railway in London." Journal of the Royal Statistical Society 126, no. 1: 46-93.

Foster, J.B. 2008. "The Financialization of Capital and the Crisis." Monthly Review 59, no. $11,1-15$.

Freeman, L. 2006. There goes the 'hood: views of gentrification from the ground up. Philadelphia, PA: Temple University.

Gale, D.E. 1979. "Middle class resettlement in older urban neighborhoods: The evidence and the implications." Journal of American Planning Association 45, no 3: 293304.

Gale, D.E. 1984. Neighborhood revitalization and the postindustrial city: a multinational perspective. Lexington, MA: Lexington Books.

Germany, K. 2004. "War on Poverty" in An Encyclopedia of History, Politics, and Policy (eds. Alice O'Connor and Gwendolyn Mink). ABC-Clio, pp. 774-782.

Gillham, B. 2000. The Research Interview. New York: Wellington House.

Glass, R. 1964. "Introduction: Aspects of change" in Centre for Urban Studies (ed.) London: Aspects of Change. London: MacKibbon and Kee.

Gotham, K. 2005. “Tourism gentrification: The case of New Orleans' Vieux Carre (French Quarter).” Urban Studies 42, no. 7: 1099-1121.

Gottdiener, M. 1985; 1994. The Social Production of Urban Space. Austin: University of Texas Press.

Graham, D.A. 1977. "Cost-Benefit Analysis Under Uncertainty.” NBER Working Paper Series, no. w0194.

Gray, R., C. Dey, D. Owen, R. Evans and S. Zadek. 1997. "Struggling with the praxis of social accounting." Accounting, Auditing \& Accountability Journal 10, no. 3: 325364. 
Gray, R. D.L Owen and C. Adams. 1996b. Accounting and Accountability: Changes and Challenges in Corporate Social and Environmental Reporting. London: Prentice Hall.

Greater Cincinnati Homeless Coalition. 2013. Print media last modified in Fall of 2013.

Gurr, T.R. 1971. Why Men Rebel. New Jersey: Princeton Press.

Hackworth, J. 2002. "Post recession gentrification in New York City." Urban Affairs Review 37, no. 6: 815-843.

Hackworth, J. and N. Smith. 2001. "The Changing State of Gentrification." Tijdschrift voor Economische en Sociale Geografie 92, no 4: 464-477.

Hackworth, J. 2002b. "Local autonomy, bond-rating agencies, and neoliberal urbanism in the United States." International Journal of Urban and Regional Research 26, no. 4: 707-725.

Hamnett, C. 1984. "Gentrification and residential location theory: A review and assessment" in Geography and the Urban Environment: Progress in Research and Applications (eds.) D. T. Herbert and R. J. Johnson. London: Wiley \& Sons, pp. 283-319.

Hamnett, C. 1991. "The blind men and the elephant: The explanation of gentrification." Transactions of the Institute of British Geographers 16, no. 2: 173-189.

Hamnett, C. 2003. "Gentrification and the middle-class remaking of inner London, 19612001.” Urban Studies 40, no. 12: 2401-2426.

Hanley, N. and C.L. Spash. 1993. Cost-benefit analysis and the environment. Northampton, MA: Edward Elgar Publishing, Inc.

Harrison, B. 1974. "Ghetto employment and the model cities program." The Journal of Political Economy 82, no. 2, part 1: 353-371.

Harte, G. 1986. "Social Accounting in the Local Economy." Local Economy 1, no. 1: 4556.

Harte, G.F. and D.L. Owen. 1987. "Fighting De-industrialization: The Role of Local Government Social Audits." Accounting, Organizations and Society 12, no. 2: 123-141.

Hartman, C. 1984. "The right to stay put" in Land Reform, American Style (eds.) C. Geisler and F. Popper. Totowa, NJ: Rowman and Allanheld, pp. 302-318.

Harvey, D. 1973. Social Justice and the City. Athens: The University of Georgia Press. 
Harvey, D. 1976. "Labor, Capital, and Class Struggle around the Built Environment in Advanced Capitalist Societies.” Politics \& Society 6, no. 3: 265-295.

Harvey, D. 1978. "The urban process under capitalism: A framework for analysis." International Journal of Urban and Regional Research 2, no.1-4: 101-131.

Harvey, D. 1982. The Limits to Capital. Chicago: University of Chicago Press.

Harvey, D. 1989. The Condition of Postmodernity. Oxford: Blackwell.

Hawley, A. 1950. Human Ecology. New York: Ronald Press.

Henig, J.R. and D.E. Gale. 1987. "The Political Incorporation of Newcomers to Racially Changing Neighborhoods." Urban Affairs Quarterly 22, no. 3: 399-419.

Imbroscio, D. 2004. “The Local Public Balance Sheet: An Alternative Evaluation Methodology for Local Economic Development" in Critical Evaluations of Economic Development Policies (eds.) L. A. Reese and D. Fasenfest. Detroit: Wayne State University Press, pp. 77-100.

Jones, L.P., P. Tandon, and I. Vogelsang. 1990. Selling Public Enterprises: a CostBenefit Methodology. Cambridge, MA: MIT Press.

King, E.M. 2003. “Accounting for Culture: A Social Cost-Benefit Analysis of The Stan Rogers Folk Festival.” (Senior thesis, Dalhousie University, September, 2003).

Krutilla, J.V. and O. Eckstein. 1958. Multiple Purpose River Development. Baltimore: Johns Hopkins Press.

Lang, M. 1986. "Measuring Economic Benefits from Gentrification.” Journal of Urban Affairs 8, no. 4: 27-39.

Laska, S.B. and D. Spain (eds.). 1980. Back to the City: Issues in Neighborhood Renovation. New York: Pergamon Press.

Lees, L. 2003a. "Visions of 'urban renaissance': The Urban Task Force report and the Urban White Paper" in Urban Renaissance? New Labour, Community and Urban Policy (eds.) R. Imrie and M. Raco. Bristol: Policy Press, pp. 61-82.

Lees, L. 2008. "Gentrification and Social Mixing: Towards an Inclusive Urban Renaissance?” Urban Studies 45, no. 12: 2449-2470.

Lees, L., and D. Ley. 2008. "Introduction to Special Issue on Gentrification and Public Policy.” Urban Studies 45, no 12: 2379-2384. 
Lees., L., T. Slater, and E. Wyly. 2008. Gentrification. London and New York: Routledge.

Lees, L., T. Slater, and E. Wyly. 2010. The Gentrification Reader. London and New York: Routledge.

Lefebvre, H. 1974. The Production of Space. Oxford: Blackwell.

Leff, N. H. 1984. "Externalities, Information Costs, and Social Benefit-Cost Analysis for Economic Development: An Example from Telecommunications.” Economic Development and Cultural Change 32, no. 2: 255-276.

Leinberger, C.B. 2001. "Taming Gentrification: Using Rising Values to Finance Affordable Housing through 'Value Latching'." Brooking's Institute, Capital Xchange.

LeGates, R.T. and C.W. Hartman. 1981. Displacement. Chicago: National Clearinghouse for Legal Services.

LeGates, R.T. and C.W. Hartman.1986. "The anatomy of displacement in the US" in Gentrification of the City (eds.) N. Smith and P. Williams. London: Unwin Hyman, pp. 178-200.

Levine, M. 2000. “A Third-World City in the First World: Social Exclusion, Racial Inequality, and Sustainable Development in Baltimore" in The Social Sustainability of Cities (eds.) M. Polese and R. Stren. Toronto: University of Toronto Press, pp. 123-156.

Levine, M. A. 2004. "Government Policy, the Local State, and Gentrification: the Case of Prenzlauer Berg (Berlin), Germany.” Journal of Urban Affairs 26, no. 1: 89-108.

Ley, D. 1980. "Liberal ideology and the postindustrial city." Annals of the Association of American Geographers 70, no. 2: 238-258.

Ley, D. 1986. "Alternative explanations for inner city gentrification: A Canadian assessment." Annals of the Association of American Geographers 76, no. 4: 521535.

Ley, D. 1987. The rent gap revisited." Annals of the Association of American Geographers 77, no. 3: 465-468.

Ley, D. 1994. "Gentrification and the politics of the new middle class." Environment and Planning D: Society and Space 12, no.1: 53-74. 
Ley, D. 1996. The New Middle Class and the Remaking of the Central City. Oxford: Oxford University Press.

Lipton, S.G. 1977. "Evidence of central city revival." Journal of the American Institute of Planners 43, no. 2: 136-147.

Logan, J. R., and H. L. Molotch. 1987. Urban Fortunes: The Political Economy of Place. Berkeley and Los Angeles: University of California Press, Ltd.

Lyons, M. 1996. "Gentrification, socio-economic change and the geography of displacement." Journal of Urban Affairs 18, no. 1:39-62.

Maag, C. 2006. "In Cincinnati, Life Breaths Anew in Riot-Scarred Area.” New York Times 25, November 6, 2006. http://www.nytimes.com/2006/11/25/us/25cincy.html?_r=2\&.

Maass, A. 1966. "Benefit-Cost Analysis: Its Relevance to Public Investment Decisions." The Quarterly Journal of Economics 80, no. 2: 208-226.

Maass, A., M.M. Hufschimdt, R. Dorfman, H.A. Thomas, S.A. Marglin and G.M. Fair. 1962. Design of Water Resource Systems: New Techniques for Relating Economic Objectives, Engineering Analysis, and Governmental Planning. London: Macmillan.

Marcuse, P. 1985. "Gentrification, abandonment and displacement: Connections, causes and policy responses in New York City." Journal of Urban and Contemporary Law 28, no. 1-4: 195-240.

McCarthy, J. D. and M. N. Zald. 1977. "Resource Mobilization and Social Movements: A Partial Theory." The American Journal of Sociology 82, no. 6: 1212-1241.

Miller, Z. and B. Tucker. 1998. Changing Plans for America's Inner Cities: Cincinnati's Over-the-Rhine and Twentieth Century Urbanism. Columbus: Ohio State University Press.

Molotch, H. L. 1972. Managed Integration: Dilemmas of Doing Good in the City. Berkley, Los Angeles and London: University of California Press.

Musto, M. 2008. Karl Marx's Grundrisse: Foundations of the critique of political economy 150 years later. New York: Routledge.

Newman, K and R. Lake. 2006. "Democracy, bureaucracy and difference in US community development politics since 1968." Progress in Human Geography 30, no. 1: 44-61. 
Newman, K. and E. Wyly. 2006. "The right to stay put, revisited: Gentrification and resistance to displacement in New York City." Urban Studies 43, no. 1: 23-57.

Owen, D. and K. Maunders. 1987. Corporate social reporting: Accounting and accountability. London: Prentice Hall.

Patterson, P. 1971. “A New Look for Model Cities: Urban Redevelopment: Vanguard of the New Federalism?. Black Enterprise, November 1971, pp. 17-20.

Porter, E., and A. Barber. 2006. "The Meaning of Place and State-led Gentrification in Birmingham's Eastside." City Analysis of Urban Trends, Culture, Theory, Policy, Action 10, no. 2: 215-234.

PolicyLink. 2014. "ROMS: CDCs with Resident Ownership.” Accessed Winter, 2014. http://policylink.info/EDTK/ROMcdc/default.html.

Polletta, F. and J. M. Jasper. 2001. "Collective Identity and Social Movements." Annual Review of Sociology 27: 283-305.

Prest, A.R. and R. Turvey. 1965. "Cost-Benefit Analysis: A Survey.” The Economic Journal 75, no. 300: 683-735.

Punch, K.F. 1998. Introduction to Social Research: Quantitative and Qualitative Approaches. London: Sage.

Rose, D. 1984. "Rethinking gentrification: Beyond the uneven development of Marxist urban theory." Environment and Planning D: Society and Space 2, no.1: 47-74.

Rubin, H. and I. Rubin. 2005. Qualitative Interviewing: The Art of Hearing Data. Thousand Oaks, CA: Sage Publications.

Rutland, T. 2010. "The Financialization of Urban Redevelopment." Geography Compass 2, no. 6: 1-12.

Rusk, David. 1993. Cities Without Suburbs. Baltimore: Johns Hopkins University Press.

Sassen, S. 1991. The Global City: New York, London and Tokyo. Princeton, NJ: Princeton University Press.

Schechter, J.H. 2011. “An Empirical Evaluation of the Model Cities Program.” (Thesis, University of Michigan, March 11, 2011).

Scheer, B.C. and D. Ferdelman. 2001. "Inner-city destruction and survival: the case of Over-the-Rhine, Cincinnati." Urban Morphology 5, no. 1: 15-27.

Schumpeter, J.A. 1942. Capitalism, Socialism and Democracy. New York: Routledge. 
Slater, T. 2004. "Municipally-managed Gentrification in South Parkdale, Toronto." The Canadian Geographer 48, no. 3: 303-325.

Slater, T. 2004. "North American gentrification? Revanchist and emancipator perspectives explored." Environment and Planning A 36, no. 7: 1191-1214.

Smelser, W.T. 1963. "Personality and Social Systems." Journal of Abnormal and Social Psychology 62, no. 3: 535-542.

Smith, D. and P. McGuigan. 1979. Towards a Public Balance Sheet: Calculating the Costs and Benefits of Community Stabilization. Washington DC: National Center of Economic Alternatives.

Smith, N. 1979. "Toward a theory of gentrification: A back to the city movement by capital, not people." Journal of the American Planning Association 45, no. 4: 538548.

Smith, N. 1996a. The New Urban Frontier: Gentrification and the Revanchist City. London and New York: Routledge.

Smith, N. 2002. "New globalism, new urbanism: Gentrification as global urban strategy." Antipode 34, no. 3: 427-450.

Smith, N. and J. DeFilippis. 1999. "The reassertion of economics: 1990s gentrification in the Lower East Side." International Journal of Urban and Regional Research 23, no. 4: 638-653.

Smith, M. and J. Feagin (eds.). 1995. The Bubbling Cauldron: Race, Ethnicity, and the Urban Crisis. Minneapolis: University of Minnesota Press.

Sofaer, S. 1999. "Qualitative Methods: What Are They and Why Use Them?" Health Services Research 34, no. 5: 1101-1118.

Spencer, H. 1909. Principles of Sociology. New Haven, CT: Archon Books.

Stone, C.N. 1981. "Book Review Essay: Community Power Structure-a Further Look." Urban Affairs Review 16, no. 4: 505-515.

Strauss, A. and J. Corbin. 1998. Basics of Qualitative Research (2 ${ }^{\text {nd }}$ ed.). Newbury Park, CA: Sage.

Taylor, R.B. and J. Covington. 1988. "Neighborhood Changes in Ecology and Violence." Criminology 26, no. 4: 553-591.

Thomas, D. R. 2006. "A General Inductive Approach for Analyzing Qualitative Evaluation." American Journal of Evaluation 27, no. 2: 237-246. 
Tilly, C. 1973. “Do Communities Act?.” Sociological Inquiry 43, no. 3-4: 209-238.

Turner, J. 1978. The Structure of Sociological Theory. Homewood, IL: Dorsey.

Turner, R. and L. Killian. 1957. Collective Behavior. Englewood Cliffs, NJ: Prentice Hall.

Uitermark, J., J. W. Duyvendak, and R. Kleinhans. 2007. "Gentrification as a Governmental Strategy: Social Control and Social Cohesion in Hoogvliet, Rotterdam." Environment and Planning A 39, no. 1: 125-141.

Waldhorn, J.L. and S.A. Waldhorn. 1972. "Model Cities: Liberal Myths and Federal Interventionist Programs." Urban Law Journal; Journal of Urban and Contemporary Law 1, no. 4: 45-55.

Watt, P. 2009. "Housing Stock Transfers, Regeneration and State-led Gentrification in London." Urban Policy and Research 27, no. 3: 229-242.

Waymer, D. 2012. "A City Divided." in Culture, Social Class, and Race in Public Relations: Perspectives and Applications. Lanham, MD: Lexington Books, pp. 31-44.

Weber, R. 2002. "Extracting value from the city: neoliberalism and urban redevelopment." Antipode 34, no. 3: 519-540.

Weisbrod, B.A. 1960. Economics of Public Health: Measuring the Economic Impact of Diseases. Philadelphia: University of Pennsylvania Press.

Wilson, D., J. Wouters, and D. Grammenos. 2004. "Successful protect-community discourse: spatiality and politics in Chicago's Pilsen neighborhood." Environment and Planning A 36, no. 7: 1173-1190.

Wilson, W.J. 1989. "The Cost of Racial and Class Exclusion in the Inner City." Annals of the American Academy of Political and Social Science 501, no. 1: 8-25.

Wyly, E., and D. Hammel. 1999. "Islands of Decay in Seas of Renewal: Urban Policy and the Resurgence of Gentrification." Housing Policy Debate 10, no. 4: 711-771.

Wyly, E. and D. Hammel. 2000. "Capital's metropolis: Chicago and the transformation of American housing policy." Geografiska Annaler B 82, no. 4: 181-206.

Wyly, E.K., and D.J. Hammel. 2004. "Gentrification, segregation, and discrimination in the American urban system." Environment and Planning A 36: 1215-1241. 
Yeung, H.W. 1997. "Critical realism and realist research in human geography: a method or a philosophy in search of a method?." Progress in Human Geography 21, no. 1: $51-74$.

Zukin, S. 1982. Loft Living: Culture and Capital in Urban Change. Baltimore: Johns Hopkins University Press.

Zukin, S. 1991. "Gentrification as Market and Place," from "Gentrification and cuisine" in Landscapes of Power: From Detroit to Disney World. Berkeley: University of California Press. 
APPENDIX

INTERVIEW QUESTIONS

\section{(i). Common Questions for Key Informants (City, Chamber of Commerce, and Cincinnati Center City Development Corporation)}

1. Why was Over-the-Rhine (OTR) chosen as an area for revitalization?

a. Did you draw inspiration from revitalization projects in other cities?

i. If so, which ones?

ii. Were there any pitfalls or hazards that you knew you would face?

iii. What were you most apprehensive about?

iv. What were you most enthusiastic about?

2. During the revitalization process, what is the role played by the [entity]?

3. Who are all the "actors" involved in the revitalization process?

4. How did this revitalization project progress from an idea to completed project phases?

a. Who, in particular, were the most influential people in getting the ball rolling?

b. When the project faced challenges, who were the key players involved in pushing the project forward?

5. Was there political opposition?

a. Who led the opposition?

i. Was support or opposition to the project divided along party lines or racial lines?

b. How were the conflicts resolved?

\section{(ii). Individual Questions}

City:

1. If I were deciding to move to Cincinnati, how would you "sell" OTR to me?

2. Do you think it's fair to say that OTR has had a negative reputation in the past? 
a. What were some of the negative stereotypes that come to mind?

3. How does the city attract developers to OTR (given its negative reputation)?

4. How does the city attract businesses to the area (e.g., tax breaks)?

5. How has the city improved the reputation of OTR as being a crime ridden, dangerous place to live?

6. Do you think the new residents' expectations are met once they move to OTR?

a. If so, how?

b. If not, why?

7. Are the new residents able to find services such as coffee shops, dry cleaners, daycare etc. that they would have used in their previous communities?

a. Can you give me examples of such services?

8. How much has the city invested so far in the revitalization projects in OTR?

a. How much has the city invested in the building of infrastructure (roads, street lights, water, sewer)?

9. How does the city decide to invest money in a particular project?

a. Who is the most influential person or entity in making that decision?

b. Where do the monies come from?

10. What are some intangible costs associated with the revitalization project in OTR?

11. What are some of the social costs associated with the revitalization project in OTR? And by social costs, I mean sense of community, family cohesion, pride in the community, loyalty etc.

12. What are some of the financial benefits of revitalization projects in the OTR?

a. Has there been an increase in property tax revenues?

i. How much?

ii. What is the expected increase over the next ten years?

13. What are some of the social benefits of revitalization projects in OTR?

a. Who is benefiting from the revitalization projects?

14. What are some intangible benefits associated with the revitalization projects in OTR?

a. Who is benefiting from these intangibles?

15. Has there been an increase in employment in OTR as a result of the revitalization efforts?

a. Can you give me a number?

b. What kind of jobs?

c. What is the average wage?

d. Do the jobs give benefits?

e. How many of the jobs have gone to longtime existing residents?

16. What happens to the longtime existing residents as a result of the new development?

a. Do they have to move? 
b. Do you have any statistics on how many longtime residents have moved since the revitalization began?

c. What does the city do if the longtime existing residents cannot afford the new rents or mortgages?

17. Does the city give housing assistance to those getting displaced?

a. In what form?

b. What percentage of housing assistance goes to children?

c. Has the money spent on housing assistance changed since the revitalization in OTR?

i. Do you have specific numbers on this?

18. How does the city encourage developers to build affordable housing?

a. Does the city give developers incentives? If so, what kind of incentives?

b. Is it a one to one replacement?

c. What is the timeline for the realization of affordable housing from inception to completion?

d. Are longtime existing residents moved into such affordable housing?

e. What happens to the longtime existing residents while construction is taking place?

19. Could you give me as many plausible reasons as to why some longtime residents of OTR are against the revitalization?

a. What are some less than plausible reasons that longtime existing residents of OTR are against the revitalization?

20. How do you define revitalization?

a. I'm sure you've heard the term gentrification and the negative connotations associated with it. I'm sure you know that critics of gentrification claim that it displaces families and tears apart the social fabric of communities. These same critics would say revitalization is just another word for gentrification. How would you respond to these critics?

21. Tell me what has been personally the most satisfying part of being involved in the revitalization of OTR?

22. You've been very helpful. Is there anything else you would like to elaborate on or share that we didn't touch on?

\section{Over-the-Rhine Chamber of Commerce}

1. What goals does the Chamber of Commerce hope to achieve with the revitalization of OTR?

2. If I were deciding to move to Cincinnati, how would you "sell" OTR to me?

3. How does the Chamber of Commerce encourage new residents to move to OTR?

a. What is the budget for such promotional activities? 
b. What is the success rate for such promotional activities?

c. What kind of demographic do you typically target?

i. Why, in particular, that type of resident?

4. Tell me about business development. How does the Chamber of Commerce support new business development in OTR?

a. What kind of businesses does the Chamber of Commerce hope to attract to OTR?

b. Are most of the new businesses formed by existing residents or newcomers?

i. How does the Chamber of Commerce support a new business?

1. Can you give me some examples?

c. How much has the Chamber of Commerce invested in business development?

d. Where does the Chamber of Commerce get its funding from in order to provide financial incentives and assistance to new businesses?

e. Does the Chamber of Commerce do anything to ensure that the new businesses create jobs that are suitable for longtime existing residents?

i. If yes, how do you achieve this and how do you measure the outcome?

5. Tell me about the training programs. What are they? How do they work?

a. How much has the Chamber of Commerce invested in its training programs?

b. How does the Chamber of Commerce fund its training programs?

c. How do you measure whether or not your investment is paying off?

d. What have those measurements revealed?

6. Safety is an important issue. What has the Chamber of Commerce done to make OTR a safer place to live?

a. How much money has the Chamber of Commerce invested in making the streets of OTR safer?

b. How do you measure whether or not your investment is paying off?

c. What have those measurements revealed?

7. How has the Chamber of Commerce facilitated better transit opportunities for the residents?

a. How much has the Chamber of Commerce invested in improving transportation in OTR?

b. How do you measure whether or not your investment is paying off?

c. What have those measurements revealed?

8. How has the Chamber of Commerce contributed to increasing diversity in OTR?

a. How much has the Chamber of Commerce invested in its diversity initiatives? 
b. Tell me about your most successful diversity initiative.

c. Tell me about an unsuccessful diversity initiative and the lessons learned.

9. Are there any longtime residents or new residents that are active with the Chamber of Commerce? Is there anyone you could refer me to in order to get a resident's perspective?

10. What happens to the longtime existing residents as a result of the new development?

a. Do they have to move?

b. What happens if they cannot afford the new rents or mortgages?

11. How does the Chamber of Commerce encourage the retention of longtime existing residents?

23. What are some of the social costs of revitalization projects in OTR? And by social costs, I mean sense of community, family cohesion, pride in the community, loyalty etc.

12. What are some intangible costs associated with the revitalization projects in OTR?

13. What are some of the financial benefits of revitalization projects in the OTR?

14. What are some of the social benefits of revitalization projects in OTR?

15. What are some intangible benefits associated with the revitalization projects in OTR?

16. How do you define revitalization?

a. I'm sure you've heard the term gentrification and the negative connotations associated with it. I'm sure you know that critics of gentrification claim that it displaces families and tears apart the social fabric of communities. These same critics would say revitalization is just another word for gentrification. How would you respond to these critics?

17. Tell me what has been personally the most satisfying part of being involved in the revitalization of OTR?

18. You've been very helpful. Is there anything else you would like to elaborate on or share that we didn't touch on?

\section{Cincinnati Center Community Development Corporation (3CDC)}

1. How does 3CDC attract developers to build in OTR?

a. What is 3CDC's greatest success story in attracting a developer to OTR?

i. What, in particular, do you think appealed to that developer?

b. What were some of the challenges that $3 \mathrm{CDC}$ had to overcome in order to attract developers?

c. What are some concerns that a potential developer may have when considering a project in OTR? 
2. How does $3 \mathrm{CDC}$ work with developers to coordinate revitalization projects in OTR?

3. Besides developers, who are some other partners that 3CDC works with on revitalization projects in OTR?

4. How much has 3CDC invested in the revitalization efforts in OTR?

5. Where does 3CDC get its funding from?

6. Can you tell me how the CEF and CNMF funds work?

a. Who manages these funds?

b. What are the funds' investment objectives and parameters?

c. What are the criteria used to determine what project the fund invests in and how much the investment value is?

7. How does $3 \mathrm{CDC}$ decide to invest money in a particular project?

a. Where do the monies come from?

8. How much has $3 \mathrm{CDC}$ invested in the building of market-rate housing?

9. How much has $3 \mathrm{CDC}$ invested in the building of affordable housing?

10. How much has $3 \mathrm{CDC}$ invested in the building of infrastructure (roads, street lights, water, sewer)?

11. How does $3 \mathrm{CDC}$ act as a liaison between the various actors such as developers and longtime existing residents?

12. Let us talk about the existing residents. How much say do existing residents have in constructing development plans?

a. What is the process by which they are able to give input?

b. What guarantees are there that their opinions are taken into account?

13. What happens to the longtime existing residents as a result of the new development?

a. Do they have to move?

b. What happens if they cannot afford the new rents or mortgages?

14. How does 3CDC encourage the retention of longtime existing residents?

15. What are some of the social costs of revitalization projects in OTR? And by social costs, I mean sense of community, family cohesion, pride in the community, loyalty etc.

16. What are some intangible costs associated with the revitalization projects in OTR?

17. What are some of the financial benefits of revitalization projects in the OTR?

18. What are some of the social benefits of revitalization projects in OTR?

19. What are some intangible benefits associated with the revitalization projects in OTR?

20. How do you define revitalization?

a. I'm sure you've heard the term gentrification and the negative connotations associated with it. I'm sure you know that critics of 
gentrification claim that it displaces families, tears apart the social fabric of communities. These same critics would say revitalization is just another word for gentrification. How would you respond to these critics?

21. Tell me what has been personally the most satisfying part of being involved in the revitalization of OTR?

22. You've been very helpful. Is there anything else you would like to elaborate on or share that we didn't touch on?

\section{Over-the-Rhine Community Housing (OTRCH)—(develops, manages, and owns affordable housing in OTR)}

1. Can you tell me the history of the organization and what OTRCH does?

2. How many tenants do you have?

a. What percentage of those are children?

b. What percentage are 65 and older?

c. What percentage are disabled?

d. What percentage are women?

e. What percentage are people of color?

f. What percentage are single parents?

3. What is the occupancy rate?

4. How many applications do you receive per week?

5. What is the acceptance rate?

6. What is the retention rate/turnover rate?

7. On average, how long does it take an applicant to actually move into affordable housing?

8. On average, how long does a tenant stay in OTRCH housing?

9. Have you seen an increase in your tenants since the revitalization efforts (either through increasing rents or tenureship conversion or displacement)?

a. If yes, how has OTRCH handled the increase in the number of eligible applicants?

10. How has OTRCH handled an increase in its tenants?

11. How much does it cost OTRCH per tenant (in administrative costs etc.)? If an applicant is denied acceptance by $\mathrm{OTRCH}$, what are alternative housing options available to the applicant?

12. According to your estimates, as a result of the revitalization efforts, how many people end up becoming homeless?

a. Tell me how you get to that figure.

b. Are there alternative figures out there?

c. Could you share an example? 
13. According to your estimates, as a result of the revitalization efforts, how many people end up leaving OTR?

a. Tell me how you get to that figure.

b. Are there alternative figures out there?

c. Could you share an example?

14. According to your estimates, as a result of the revitalization efforts, how many people move in with relatives?

a. Tell me how you get to that figure.

b. Are there alternative figures out there?

c. Could you share an example?

15. How many affordable housing units are there in OTR?

16. How much affordable housing has been converted to market rate housing due to the revitalization process in OTR?

a. Tell me how you get to that figure.

b. Are there alternative figures out there?

c. Could you share an example?

17. How much of the revitalization efforts have focused on the building or rehabilitation of affordable housing?

a. How do you arrive at that number?

b. What might be some alternative methods for calculating that percentage?

18. Given the rate of homelessness and numbers of low-income households in OTR, has the revitalization process provided for an adequate amount of affordable housing?

a. Why do you think that is the case?

b. Do you feel like the focus of the revitalization project marginalizes the longtime existing residents?

19. What are the primary funding sources for OTRCH?

20. How does OTRCH work with the city in achieving OTRCH's goals?

21. How does OTRCH work with $3 \mathrm{CDC}$ in achieving OTRCH's goals?

22. How does OTRCH work with the Cincinnati Chamber of Commerce in achieving OTRCH's goals?

23. Who are some other partners that OTRCH works with?

24. How many of the OTRCH tenants are a part of Cornerstone Renter Equity program?

25. What are some of the social costs of revitalization projects in OTR? And by social costs, I mean sense of community, family cohesion, pride in the community, loyalty etc.

26. What are some intangible costs associated with the revitalization projects in OTR?

27. What are some of the financial benefits of revitalization projects in the OTR? 
28. What are some of the social benefits of revitalization projects in OTR?

29. What are some intangible benefits associated with the revitalization projects in OTR?

30. How do you define revitalization?

a. Is revitalization just another word for gentrification?

i. How is it different?

31. I would like to speak to some of the existing and displaced residents to get their perspective. Is there anyone I could follow up with?

32. You've been very helpful. Is there anything else you would like to elaborate on or share that we didn't touch on?

\section{Funding Source}

1. Can you tell me a little bit about your organization and what it does?

2. Who are [entity's] primary clients?

3. How does the [entity] evaluate project proposals? What are the criteria for evaluation?

4. What are the kinds of loans offered by [entity]?

5. What are the kinds of interest rates offered by [entity]?

6. How is the financing offered by [entity] comparable to that offered by a commercial bank in terms of interest rates, loan terms etc.?

7. Are loan disbursements made in a lump sum or are they broken down per the phases of the project?

8. After underwriting the loan, how involved is [entity] during the progress of the project? Do the clients have to submit progress reports?

9. Where does [entity] get its funding from?

10. How does the [entity] decide to invest money in a particular project?

11 . Where do the monies come from?

12. How much has the [entity] invested so far in the revitalization projects in OTR?

13. How much has the [entity] invested in the building of market-rate housing?

14. How much has the [entity] invested in the building of affordable housing?

15. How much has the [entity] invested in the building of infrastructure (roads, street lights, water, sewer)?

16. How does [entity] work with the city in achieving [entity's] goals?

17. How does [entity] work with $3 \mathrm{CDC}$ in achieving [entity's] goals?

18. How does [entity] work with the Cincinnati Chamber of Commerce in achieving [entity's] goals?

19. What are some of the social costs of revitalization projects in OTR? And by social costs, I mean sense of community, family cohesion, pride in the community, loyalty etc. 
20. What are some intangible costs associated with the revitalization projects in OTR?

21. What are some of the financial benefits of revitalization projects in the OTR?

22. What are some of the social benefits of revitalization projects in OTR?

23. What are some intangible benefits associated with the revitalization projects in OTR?

24. You've been very helpful. Is there anything else you would like to elaborate on or share that we didn't touch on?

\section{Social Service Organizations}

1. Get data over past ten year period.

2. Tell me all you want to tell me about the revitalization program in OTR.

3. Have you seen an increase in the number of homeless individuals as a result of the revitalization efforts in OTR?

a. How much of an increase?

b. How did you get that number?

4. What are your operating costs per month?

5. How much does it cost [entity] per homeless individual?

6. What sources of funding are available to the [entity]?

7. How does [entity] work with the city in achieving [entity's] goals?

8. How does [entity] work with $3 \mathrm{CDC}$ in achieving [entity's] goals?

9. How does [entity] work with the Cincinnati Chamber of Commerce in achieving [entity's] goals?

10. Who are some other partners that [entity] works with?

11. According to your estimates, as a result of the revitalization efforts, how many people end up becoming homeless?

a. How do you get this number?

b. Could you recommend some other sources who might also be tracking these numbers?

12. According to your estimates, as a result of the revitalization efforts, how many people end up leaving OTR?

a. How do you get this number?

b. Could you recommend some other sources who might also be tracking these numbers?

13. According to your estimates, as a result of the revitalization efforts, how many people move in with relatives?

a. How do you get this number?

b. Could you recommend some other sources who might also be tracking these numbers? 
14. What are some of the social costs of revitalization projects in OTR? And by social costs, I mean sense of community, family cohesion, pride in the community, loyalty etc.

15. What are some intangible costs associated with the revitalization projects in OTR?

16. What are some of the financial benefits of revitalization projects in the OTR?

17. What are some of the social benefits of revitalization projects in OTR?

18. What are some intangible benefits associated with the revitalization projects in OTR?

19. I am interested in speaking to some of the existing and displaced residents to get their perspective. Do you know of anyone I could follow up with?

20. You've been very helpful. Is there anything else you would like to elaborate on or share that we didn't touch on?

\section{Developers}

1. Why did you choose to develop in OTR?

2. Did you draw inspiration from revitalization projects in other cities?

a. If so, which ones?

b. Were there any pitfalls or hazards that you knew you would face?

c. What were you most apprehensive about?

d. What were you most enthusiastic about?

3. How do you attract newcomers to your developments?

4. What kind of a demographic do you typically target?

a. Why, in particular, that type of resident?

5. How does the marketing and leasing process work?

6. How do you overcome the negative reputation that OTR has, in terms of crime etc.?

7. Let us talk about a typical project, how does it progress from start to finish?

8. What kind of challenges have you faced during the course of the project?

a. How did you overcome these challenges?

9. How does the financing work?

10. What are the primary funding sources?

11. What kind of subsidies do you get?

12. Are you typically required to build a certain amount of affordable housing units along with the market rate housing?

a. If so, what kind of tax breaks do you get?

b. Is it a one for one replacement?

13. Are the street, sewer, water, lighting and other infrastructural improvements typically made by the developer or by the city? 
14. How would you describe your relationship with the city?

15. How would you describe your relationship with the existing residents?

16. Do the existing residents have a say in the development plans?

a. Why or why not?

b. How so?

17. Do you hire existing residents for the construction projects?

a. Why or why not?

18. What happens to the longtime existing residents because of the new development?

a. Do they have to move?

b. Do you know where they typically end up moving to?

19. Do longtime existing residents become your new clients/tenants?

20. Why do you think some longtime residents are against the new development?

21 . Has there been any opposition to any of your developments?

a. Has there been any vandalism, graffiti, destruction of property?

b. How did you overcome such opposition?

22. Have you had to take special security measures to protect your property?

23. What are some of the social costs of revitalization projects in OTR? And by social costs, I mean sense of community, family cohesion, pride in the community, loyalty etc.

24. What are some intangible costs associated with the revitalization projects in OTR?

25. What are some of the financial benefits of revitalization projects in the OTR?

26. What are some of the social benefits of revitalization projects in OTR?

27. What are some intangible benefits associated with the revitalization projects in OTR?

28. I would like to speak to some of the new residents. Is there anyone you could refer me to?

29. How do you define revitalization?

a. I'm sure you've heard the term gentrification and the negative connotations associated with it. I'm sure you know that critics of gentrification claim that it displaces families, tears apart the social fabric of communities. These same critics would say revitalization is just another word for gentrification. How would you respond to these critics?

30. Tell me what has been personally the most satisfying part of being involved in the revitalization of OTR?

31. You've been very helpful. Is there anything else you would like to elaborate on or share that we didn't touch on? 


\section{Gentrifiers}

1. Demographic info
a. Age
b. Race
c. Educational attainment
d. Occupation

2. Why did you decide to move to OTR?

3. Where did you move from?

4. What was your old neighborhood like?

5. Did you limit your house search to OTR?

6. Did you search for a long time before finding your current home?

a. How long?

7. Did you own your prior home?

a. Did you downsize?

b. Was it difficult selling your old home?

8. How much were your moving costs?

9. How much time did it take you to access your service needs (grocery, dry cleaner, coffee shop, night entertainment etc.)?

a. What kind of services do you use in OTR?

10. Do you still travel back to your old neighborhood for any services?
a. Which ones?
b. Why?

11. How would you describe your new neighborhood?

12. How does your new neighborhood compare to your old neighborhood?

13. Do you feel "better off' in OTR when compared to your old neighborhood?

14. Have you ever felt unsafe, threatened, or uncomfortable in OTR?

a. Tell me about it.

b. Do you know of anybody who's been mugged?

c. What precautions do you take to ensure your safety?

d. Do you avoid being out after a certain time?

e. Do you avoid certain areas?

15. What kind of interaction do you have with the longtime OTR residents?

a. Have you made any friends with longtime existing residents?

b. Have you made friends with any of the new residents?

16. Are you involved with any of the local community organizations?
a. Which ones?
b. How long have you been involved with them?
c. What are some of the main neighborhood concerns?

17. Do you feel welcomed by the longtime residents?

18. If you have children, where do your children go to school? 
a. Did they change schools once you moved to OTR?

i. Do they like their new school?

ii. Have they made new friends?

iii. Are you active in the parent-teacher-association?

19. How has your commuting to work time changed as a result of moving to OTR?

20. What are some of the positives of moving to OTR?

21 . What are some of the negatives of moving to OTR?

22. Do you have any stories or anecdotes that typify life in OTR?

\section{Longtime Existing Residents}

1. Demographic info
a. Age
b. Race
c. Educational attainment
d. Occupation

2. Tell me about yourself and how long you've lived in OTR and what your experience has been like.

3. How would you describe OTR to a stranger?

4. Do you have a lot of family and friends who also live in OTR?

5. Have any of your family and friends moved?

a. Why did they move?

b. Has that strained the relationships?

c. How far away did they move?

d. Do you have a car?

i. If not, how easy is it to catch a bus to visit them?

6. Have you noticed a decline in church membership since the revitalization project began?

a. Could you give any examples?

7. Have you noticed a strain on social services since the revitalization project in OTR?

8. What has happened to the job situation since the revitalization project in OTR?

9. Have you noticed higher prices (for example, at the grocery store) since the revitalization project in OTR?

10. Have your property taxes or rents gone up since the revitalization project in OTR?

11. Do you have to travel now to go to establishments that have moved since the revitalization, such as the barber shop, church, pool hall etc.?

12. What are some improvements to the OTR neighborhood as a result of the revitalization projects?

13. How much voice do the longtime residents have in the revitalization plans? 
14. What are some of the drawbacks of the revitalization projects?

15. Are you for or against the revitalization projects?

a. Why?

16. In your opinion, what is the general feel in the community about the revitalization projects?

17. How much activism is there in the community?

a. Who are the activists?

b. What methods of activism are used?

c. What are the costs?

d. What are the benefits?

e. Where is the funding coming from?

18. Are you actively involved in the people's movement?

19. What are the benefits of having newcomers to OTR?

20. What are some of the negatives of having newcomers to OTR?

21. How do you interact with the newcomers?

a. Have you made any friends with the newcomers?

22. In general, what is the interaction like between longtime existing residents and newcomers?

23. Do you think the arrival of the newcomers has created any racial tensions?

24. Sometimes communities are divided along racial lines. Other times the division is between existing residents and newcomers. Do you think existing residents of different races are more cohesive than existing residents and newcomers of the same race?

25. Before the revitalization, would you say that blacks and whites in OTR felt and acted like a part of the same community?

a. Has that changed since the revitalization?

26. Do you think you will move out of OTR?

a. If yes, why is that?

27. You've been very helpful. Is there anything else you would like to elaborate on or share that we didn't touch on?

\section{Displaced Residents}

1. Demographic info
a. Age
b. Race
c. Educational attainment
d. Occupation

2. Tell me about living in OTR?

3. When did you move from OTR? 
4. Why did you move?

5. How long did it take you to find a new place to live?

6. How do you like the new neighborhood?

7. Do you think your new neighborhood is safer?

8. I'd like to ask you a few questions about how much it cost you to move:

a. Were you renting?

i. If yes, how much more are you now paying in rent?

b. Were you a homeowner?

i. If yes, were you able to make a profit on the sale of your house?

ii. How long did it take you to sell your house?

iii. Do you own your current house?

iv. How does your new house compare to your old house?

v. Did you have to go from being a home owner to a renter?

vi. How would you compare your current apartment/house to your old house?

9. Was there room for everyone living in your former home to move into your new home?

a. If somebody had to move, where did they go?

10. Have you made friends with your new neighbors?

a. Do you feel those bonds are as strong as your OTR neighbors?

11. Did you lose your job as a result of the move?

a. Did the job loss have anything to do with transportation difficulties?

b. Have you found a new job?

i. If so, how long did it take?

12. Has your commuting time to work increased as a result of the move?

a. Have you figured out the increased cost of your longer commute?

13. How does commuting time affect time with kids and how does it affect them?

14. Impact on children

a. Daycare hours post-move?

b. Did your children have to switch schools in the middle of the school year?

c. How many kids get held back a grade?

d. How do your kids like the new school?

e. Have they made friends?

f. How do you like the new school?

15. Do you regularly socialize with residents of your new neighborhood?

16. Did you attend a church in or close to OTR?

a. Do you still attend the same church?

i. How long does that commute take?

ii. How much does it cost to travel back to OTR? 
b. If you are attending a new church, how long did it take you to find that church?

i. Do you feel as supported by the new church as you did by the OTR church?

17. How often do you go back to OTR?

a. What are the main reasons for going back?

b. How long does it take to get there?

c. How much does it cost to get there?

18. Has your commuting time to the grocery store increased as a result of the move?

a. By how much?

19. What are the benefits of moving?

a. Are you happier after the move?

20. Would you ever move back to OTR?

21. What kinds of support services were available to you during your move?

22. What kinds of support services were available to you after your move?

23. Did you receive any financial assistance?

a. From which agencies?

24. I'm going to ask you about what you gained and what you lost by moving:

a. What did you gain and lose socially?

b. Financially?

c. Emotionally?

d. Spiritually?

25. So let's end on a bright note, tell me what's the best thing that has happened to you since you moved to the new neighborhood.

26. You've been very helpful. Is there anything else you would like to elaborate on or share that we didn't touch on? 


\section{CURRICULUM VITAE}

\section{SHIREEN DEOBHAKTA}

Department of Urban and Public Affairs 426 W. Bloom St.

Louisville, KY 40208

Email: shireenmail@gmail.com
Home Address: 3750 Boone St

Louisville, KY 40208

Cell Phone: $\quad$ 502-836-0376

\section{EDUCATION:}

University of Louisville, Louisville, Kentucky, expected defense May, 2014

Ph.D, Urban and Public Affairs

- Graduate Research Assistantship

- Dissertation: “Analysis of Social Costs of Gentrification in Over-the-Rhine." (Chair: Dr. Cynthia Negrey)

Ohio State University, Columbus, Ohio, 2004

Master of Business Administration

Ohio Wesleyan University, Delaware, Ohio, 2000

Bachelor of Arts in International Business

- Semester off-campus in Philadelphia, Pennsylvania, Fall 1998

\section{PROFESSIONAL AND RESEARCH EXPERIENCE:}

Consultant, Louisville, Kentucky, Summer 2013

Grant from the Lexington Metropolitan Housing Authority

- Evaluation of Bluegrass HOPE VI Project

University of Louisville, School of Urban \& Public Affairs, Louisville, Kentucky, January 2008

- Current

Graduate Research Assistant; Instructor

- Bourassa, Steven C., Martin Hoesli, Elias Oikarinen, Shireen Deobhakta. "Measurement of house price bubbles," work in progress.

- Contributed to article by Bourassa, Steven C. "The Political Economy of Land Value Taxation." Richard F. Dye and Richard W. England. Cambridge, MA: Lincoln Institute of Land Policy (2009). 
- Contributed to chapter by Weinberger, Rachel, and Frank Goetzke. "Drivers of Auto Ownership: The Role of Past Experience and Peer Pressure." Auto Motives: Understanding Car Use Behaviours (2011): 121.

- Collected and analyzed data for the Kentucky State Data Center.

- Prepared Housing Market Reports using Costar and CCIM software.

- Performed research on Pennsylvania Land Use Taxation policies.

- Collected data for mortgage delinquency rates for Counties in Kentucky; mapped mortgage delinquency rates using GIS software.

Strayer University, Louisville, KY, Fall 2010, Summer 2012

Adjunct Professor

Huntington Capital Corporation - Investment Banking Group, Columbus, Ohio, April 2004 December 2005.

Assistant Vice President

Bank One - Public Finance Group, Columbus, Ohio, August 2000 - April 2004.

Senior Municipal Originator

Pro-bono work in the field of Housing:

Network Center for Community Change - vacant property mapping project.

\section{TEACHING EXPERIENCE}

\section{University of Louisville}

- Urban Political Economy (POLS 302), Fall 2011.

- Housing Policy (POLS 405), Spring 2012.

- Teaching assistant responsibilities for MBA Real Estate Finance (College of Business), Fall 2009.

- Teaching assistant responsibilities for Urban Economics (UPA 603), Spring 2011.

- Teaching assistant responsibilities for Economic Development (UPA 632), Spring 2011.

\section{Strayer University}

- Managerial Economics (ECO 550), Fall 2010.

- Introductory Finance (FIN 100), Spring 2012.

\section{PAPERS AND RESEARCH:}

"Greater Louisville Project 2010 Competitive City Report," Greater Louisville Inc., Kentucky State Data Center, Contributor.

Urban Land Institute, Heines Competition, Spring 2010. 
PROFESSIONAL SKILLS:

- Research

$\circ$ Quantified and analyzed risk variables for underwriting.

$\circ$ Utilized fixed income mathematics and financial modeling for pricing securities.

$\circ$ Analyzed portfolio performance results against benchmarks.

- Performed research for securitization of portfolio.

- Modeling and Analysis

○ Developed pricing models, metrics and methodology based on extensive market data analysis and modeling.

- Modeled, quantified and analyzed risk within portfolio and asset classes.

- Origination

- Managed the appropriation-backed debt products for 3 of Bank One's largest client accounts (State of West Virginia, New Jersey and Florida), and developed marketing strategies to further market penetration.

○ Expanded real property program for municipal borrowers within Bank One's footprint states.

○ Originated 363\% (\$25.4 million) of annual budget for fiscal year 2001.

- Originated and structured new issue securities for private placement portfolio.

- Management

○ Co-managed the development of a new business group within Huntington Capital Corporation's Investment Banking Group directly reporting to Huntington National Bank's Executive Management Team.

○ Worked closely with members of Risk Management, Portfolio Management, Asset Specialization, Investment Accounting, Compliance, Legal and Operations departments to create policy and procedures for transactional flow from origination to close, including post-closing operational functions.

○ Maintained compliance with regulatory and statutory requirements.

o Originated and structured securities for private placement portfolio as well as trading portfolio.

- Computer Skills

○ Microsoft Office (Word, Excel, PowerPoint, Access), Super Trump, Seibel, Lotus Notes, Bloomberg, GIS, Costar, SPSS, SAS, NVivo.

\section{PROFESSIONAL DEVELOPMENT OPPORTUNITIES}

Institutional Review Board (IRB) training and certification.

Grant Writing Academy, School of Interdisciplinary and Graduate Studies, University of Louisville.

\section{PROFESSIONAL LEADERSHIP}

Served as President of School of Urban \& Public Affairs Ph.D Student Organization (2009-2010).

Served as Student Leader of search committee for Faculty and Director of Kentucky State Data Center position. 


\section{HONORS}

Two-thirds educational costs funded via scholarship during entire tenure at Ohio Wesleyan University.

\section{MEMBERSHIPS}

Urban Affairs Association

American Planning Association

The Urban Salon

Metropolitan Housing Coalition

Over-the-Rhine Community Housing

\section{SERVICE}

The Homeless Coalition of Greater Cincinnati

Center for Community Progress

Network Center for Community Change

Center for Neighborhoods

Food in Neighborhoods

Power Members for Food 